\title{
Pollution from the 2014-15 Bárðarbunga eruption monitored by snow cores from the Vatnajökull glacier, Iceland
}

Iwona Galeczka ${ }^{1 *}$, Eydis Salome Eiriksdottir ${ }^{2}$, Finnur Pálsson ${ }^{3}$, Eric Oelkers ${ }^{3,4}$, Stefanie Lutz ${ }^{5}$, Liane G. Benning 5,6, Andri Stefánsson ${ }^{3}$, Ríkey Kjartansdóttir ${ }^{3}$, Jóhann Gunnarsson-Robin ${ }^{3}$, Shuhei Ono ${ }^{7}$, Rósa Ólafsdóttir ${ }^{3}$, Elín Björk Jónasdóttir ${ }^{8}$ and Sigurdur R. Gislason ${ }^{3}$

${ }^{1}$ ISOR, Icelandic Geosurvey, Grensasvegur 9, 109 Reykjavik, Iceland

${ }^{2}$ Marine and Freshwater Research Institute, Skulagata 4, 101 Reykjavík, Iceland

${ }^{3}$ Institute of Earth Sciences, University of Iceland, Sturlugata 7, 101 Reykjavik, Iceland

${ }^{4}$ CNRS URM 5563; GET, 14 rue Edouard Belin, Toulouse, FRANCE, and Earth Sciences, University College London, Gower Street, WC1E 6BT, London, UK

${ }^{5}$ German Research Centre for Geosciences GFZ, Telegrafenberg, 14473 Potsdam, Germany

${ }^{6}$ Department of Earth Sciences, Free University of Berlin, 12249 Berlin, Germany

${ }^{7}$ Department of Earth, Atmospheric and Planetary Sciences, Massachusetts Institute of Technology, Cambridge, MA 02139, USA

${ }^{8} \mathrm{IMO}$, Icelandic Meteorological Office, Bustadavegi 7-9, 108 Reykjavik, Iceland

*Iwona.M.Galeczka@isor.is, tel: +354 5281512

Submitted to the Journal of Volcanology and Geothermal Research, May 9, 2017 


\section{ABSTRACT}

The chemical composition of Icelandic rain and snow is dominated by marine aerosols, however human and volcanic activity can also affect these compositions. The six month long 2014-15 Bárðarbunga volcanic eruption was the largest in Iceland for more than 200 years and it released into the atmosphere an average of $60 \mathrm{kt} /$ day $\mathrm{SO}_{2}, 30 \mathrm{kt} /$ day $\mathrm{CO}_{2}, 500 \mathrm{t} / \mathrm{day} \mathrm{HCl}$ and $280 \mathrm{t} /$ day HF. To study the effect of this eruption on the winter precipitation, snow cores were collected from the Vatnajökull glacier and the highlands northeast of the glacier. In addition to 29 bulk snow cores from that precipitated from September, 2014 until March, 2015, two cores were sampled in 21 and 44 increments to quantify the spatial and time evolution of the chemical composition of the snow.

The $\mathrm{pH}$ and chemical compositions of melted snow samples indicate that snow has been affected by the volcanic gases emitted during the Bárðarbunga eruption. The $\mathrm{pH}$ of the melted bulk snow cores ranged from 4.41 to 5.64 with an average value of 5.01. This is four times greater $\mathrm{H}^{+}$ activity than pure water saturated with the atmospheric $\mathrm{CO}_{2}$. The highest concentrations of volatiles in the snow cores were found close to the eruption site as predicted from CALPUFF $\mathrm{SO}_{2}$ gas dispersion quality model. The anion concentrations (mainly $\mathrm{SO}_{4}, \mathrm{Cl}$, and $\mathrm{F}$ ) were higher and the $\mathrm{pH}$ was lower compared to equivalent snow samples collected during 1997-2006 from the unpolluted Icelandic Langjökull glacier. Higher $\mathrm{SO}_{4}$ and $\mathrm{Cl}$ concentrations in the snow compared with the unpolluted rainwater of marine origin confirms the addition of a non-seawater $\mathrm{SO}_{4}$ and $\mathrm{Cl}$. The $\delta^{34} \mathrm{~S}$ isotopic composition confirms that the sulphur addition is of volcanic aerosol origin.

The chemical evolution of the snow with depth reflects changes in the lava effusion and gas emission rates. Those rates were the highest at the early stage of the eruption. Snow that fell during that time, represented by samples from the deepest part of the snow cores, had the lowest $\mathrm{pH}$ and highest concentrations of $\mathrm{SO}_{4}, \mathrm{~F}, \mathrm{Cl}$ and metals, compared with snow that fell later in the winter. Also the Al concentration, did exceed World Health Organisation drinking water standard of $3.7 \mu \mathrm{mol} / \mathrm{kg}$ in the lower part of the snow core closest to the eruption site.

Collected snow represents the precipitation that fell during the eruption period. Nevertheless, only minor environmental impacts are evident in the snow due to its interaction with the volcanic aerosol gases. This minor environmental impact evidenced by the microbial communities identified in the snow that fell during the eruption. These communities were similar to those found in snow from other parts of the Arctic, confirming an insignificant impact of this eruption the snow microecology.

\section{INTRODUCTION}

Volcanic eruptions pose environmental risks and monitoring of volcanic activities is a major task for the geoscientific community. Volcanic hazards include degassing, volcanic gas dispersion, acid rain, pollution of surface waters, potential volcanic ash production and glacial outburst 
floods. These hazards have been previously investigated and used for civil- and environmental protection development in vicinities of the active volcanoes (e.g., Aiuppa, 2009; Aiuppa et al., 2006, 2007, Bagnato et al., 2013; Björnsson, 2003; Bobrowski et al., 2007; Calabrese et al., 2011; Cuoco et al., 2013; D'Alessandro et al., 2013; Delmelle, 2003; Delmelle et al., 2002; Delmelle et al., 2007; Delmelle et al., 2015; Flaathen and Gislason, 2007; Floor et al.,-2011; Galeczka et al., 2014; Gislason et al., 2002; 2011; Gudmundsson et al., 1997, 2008; Jones et al., 2011; Kristmannsdóttir et al., 1999; Moune et al., 2006; Menard et al., 2014; Oppenheimer 2003; Roberts et al., 2000; Russell et al., 2006, 2010; Snorrason et al., 2002; Stefánsdóttir and Gislason, 2005; Thordarson and Self, 2003; Thordarson and Larsen, 2007; Tómasson, 1996).

The 2014-2015 Bárðarbunga eruption (Sigmundsson et al, 2015, Gislason et al., 2015, Galeczka et al. 2016; Gudmundsson et al., 2016; Gauthier et al. 2016, Stefánsson et al. 2017a) brought the possible effects of sustained eruptive degassing in the troposphere to the world's attention. Eruption vents during the 2014-15 Bárðarbunga eruption were located on the outwash plains of the Dyngjujökull glacier, on the historical Holuhraun lava that erupted between 1794 and 1864 (Fig. 1; Hartley and Thordarson, 2013). In this manuscript, the 2014-15 lava field will be referred to as the Holuhraun lava. The lava produced during this activity covered an area of $84.1 \pm 0.6$ $\mathrm{km}^{2}$ and the volume was estimated to be $1.6 \pm 0.3 \mathrm{~km}^{3}$ (Gislason et al. 2015; Gudmundsson et al. 2016) making it the largest eruption in Iceland since the 1783-84 Laki eruption (Thordarson and Larsen, 2007). Ground based and satellite remote sensing presented by Arason et al., (2015) indicate that substantial $\mathrm{SO}_{2}$ was continuously emitted to the troposphere during the eruption with plumes reaching 1-3 km in height. The total gas emissions to the atmosphere during the Bárðarbunga eruption were $11.2 \mathrm{Mt}$ of $\mathrm{SO}_{2}, 6 \mathrm{Mt}$ of $\mathrm{CO}_{2}, 0.1 \mathrm{Mt}$ of $\mathrm{HCl}$, and $0.05 \mathrm{Mt} \mathrm{HF}$ (Gislason et al., 2015; Stefánsson et al. 2017). For comparison,global volcanic $\mathrm{SO}_{2}$ emissions from all the Earth's volcanoes are on the order of 7.5-10.5 Mt (Halmer et al., 2002). The 2014-15 Bárðarbunga eruption gas emission rate caused anomalously high atmospheric $\mathrm{SO}_{2}$ concentrations in Iceland and several locations in Europe (Gislason et al., 2015; Schmidt et al., 2015 ) with an average emission rates of $62 \mathrm{kt} /$ day during the eruption and up to $133 \mathrm{kt} /$ day during September 2014 (calculated using petrologic method and DOAS measurements; Gislason, 2015; IMO, 2017). Similar $\mathrm{SO}_{2}$ fluxes were reported by Gauthier and co-workers (2016) and equalled $97 \mathrm{kt} /$ day). These high emissions affected rain and snow chemical composition all over Iceland (Gislason et al., 2015; Stefánsson et al., 2017a)..

During winter and/or in cold areas, gasses and aerosols sourced by natural and manmade activities are transported and may accumulate in snow. Globally, aerosols are sourced from oceans (1000 Mt/yr), soils or continental surface (so called continental aerosols; 100-1000 $\mathrm{Mt} / \mathrm{yr}$ ), and anthropogenic and volcanic activities (Shaw, 1989). A large portion of the annual precipitation in Iceland falls as snow. Volcanic activity considerably affects the snow chemical composition, mainly via deposition of volcanic ash particles and gaseous aerosols. Volcanic aerosols are abundant in the vicinity of erupting volcanoes, and some may be dispersed around the globe. These aerosols form during condensation of gases and their composition might be modified due various processes e.g., coagulation, evaporation, and interaction with other gases, 
organic compounds, volatiles, and other particles (e.g., Jacobson, 1998; IPCC, 1994; Seinfeld and Pandis, 2006). Snow has been shown to incorporate aerosols and gases during snowfall, (Budhavant et al., 2014; Mogono 1979; Paramonov et al., 2011). Notably, below the clouds, aerosol particles tend to be scavenged on the rim of ice crystals (Pruppacher and Klett, 1997). Aerosols can be also scavenged directly by cloud droplets (e.g., Jacobson, 1998; Seinfeld and Pandis, 2006). Because of the shapes, densities and growth mechanisms of snow crystals, the removal of aerosols from the atmosphere by snow is far more efficient than by rain based on equal equivalent water content of the precipitation (Andronache, 2009; Graedel and Franey, 1975; Jylha, 2000; Kyro et al., 2009). Aerosols scavenged by snow will dissolve during snow melt and the trapped, often acidic gases will lower the $\mathrm{pH}$ of the meltwater (e.g. Flaatheen and Gislason, 2007; Galeczka et al., 2016).

As indicated by laboratory and field experiments, 50-80\% of the pollutants in snow (including protons as a source of acidity) are released with the first $30 \%$ of the meltwater and this first meltwater fraction may contain more than five times the average snowpack ionic concentrations (Johannessen and Henriksen, 1978). Melting of 10\% of the 1987-88 winter snowpack on the Vatnajökull glacier produced meltwater more than one $\mathrm{pH}$ unit lower than the original snowpack's pH (Gislason, 1990). As shown earlier in northern North America, Scandinavia and Britain, accumulation of polluted snow during the winter and subsequent spring melt caused acidification, decreasing local lake and stream $\mathrm{pH}$ by 1 to $1.5 \log$ units (Davies 1989; Tranter, 1989; Wigington, 1989). An increase in toxic element concentrations (e.g., lead) have been recorded in Greenland and Antarctic snow and ice in response to the atmospheric anthropogenic emissions (Bautron et al., 1991, 1998, Candelone et al., 1995; Hong et al., 1994, 1996). Snow also accumulates volcanic pollutants such as fluoride and aluminium (e.g., Flaathen and Gislason, 2007; Moune et al., 2006; Galeczka et al., 2016). Melting of such polluted snow, therefore, leads to the release of these toxic elements to aquifers and surface waters (Flaathen and Gislason, 2007).

In this study we report on the chemical, isotopical and microbiological composition of snow accumulated during the 2014-15 Bárðarbunga volcanic eruption on the Vatnajökull glacier and the highlands NE of the glacier. We studied the spatial and temporal evolution of the chemical composition of the snow, as it reflects fluctuations in the eruption effusion and emission rates, wind direction and distance from the eruption source. Sulphur isotopes were applied to determine the source(s) and reactions of sulphur in these systems (e.g., Herut et al. 1995; Gunnarsson-Robin et al., 2017). In addition we analysed consequences of the snow microbial community composition using high-throughput sequencing. The purpose of this communication is to report the results of this study, which further illuminates the effects of the emission of volcanic gases on precipitated snow. 


\section{GEOGRAPHICAL AND GEOLOGICAL SETTINGS}

About $11 \%$ of Iceland is covered by glaciers; their regional distribution is dictated by topography and precipitation, which are dominated by prevailing southerly winds (Björnsson and Pálsson, 2008). The glaciers contain about $3,600 \mathrm{~km}^{3}$ of water, which is equal to about 200 years of winter precipitation on these glaciers, based on the 2014-15 snow mass balance measurements (Pálsson et al., 2015). The Vatnajökull glacier has around 30 outlet glaciers flowing from the ice cap and feeding some of the largest rivers in Iceland, including the Jökulsá á Fjöllum, which was affected by the 2014-15 Bárðarbunga eruption (Gislason et al., 2015; Galeczka et al., 2016). These rivers transport dissolved and suspended material to the oceans, affecting the elemental budget of the coastal waters (Eiriksdottir et al., 2015; 2017). The Vatnajökull is located on a highland plateau, $600-800 \mathrm{~m}$ a.s.l. with $88 \%$ of its base above $600 \mathrm{~m}$ and only $20 \%$ exceeding $1100 \mathrm{~m}$, which is the glaciations limit for southern Iceland (Björnsson and Pálsson, 2008). It is located far from anthropogenic aerosols sources (Gislason, 1990), thus changes in chemical constituents in the snow are largely influenced by volcanic inputs if present.

About $60 \%$ of the surface underneath Vatnajökull glacier contains active volcanoes (Björnsson and Einarsson, 1990; Björnsson and Pálsson, 2008). There are several central volcanoes beneath the glacier, including Gjálp that erupted in 1996, Grímsvötn that erupted in 1998, 2004 and 2011, Bárðarbunga whose eruption ended in February 2015, and Hamarinn, whose cauldrons were the source of a modest flood during 2011 (Gudmundsson and Högnadóttir, 2007; Gudmundsson et al., 1997; Hreinsdóttir et al. 2014; Hannesdóttir, 2011; Galeczka et al. 2014b; Gislason et al., 2002, 2015; IMO, 2017; Sigmundsson et al., 2015). Large glacial floods are common from geothermal and volcanic areas underneath the Vatnajökull glacier (Björnsson, 1998, 2003; Björnsson and Einarsson, 1990; Gislason et al., 2002, Stefánsdóttir and Gislason 2005). For example the 1996 Gjálp eruption melted about $4 \mathrm{~km}^{3}$ of ice (Björnsson and Pálsson, 2008). This resulted in a flood into Skeiðará river with a peak discharge of $52,000 \mathrm{~m}^{3} / \mathrm{s}$ (Gislason et al., 2002).

\section{CHEMICAL COMPOSITION OF ICELANDIC RAIN AND SNOW}

The Icelandic rain water and snow is characterized with $\mathrm{Na} / \mathrm{Cl}, \mathrm{K} / \mathrm{Cl}, \mathrm{Mg} / \mathrm{Cl}$ and $\mathrm{Sr} / \mathrm{Cl}$ ratios close to the corresponding oceanic ratios (Bruland, 1983) indicating a primary marine origin of these ions (Gislason, 1990; Gislason et al., 1996). The solute concentration in Icelandic precipitation decreases with increasing distance from the Atlantic Ocean indicating sea-spray as its principal source (Gislason and Eugster, 1987b; Gislason, 1993; Sigurdsson and Einarsson, 1988). The solute concentration of rainwater is higher in the winter than during the summer (Gislason and Eugster 1987b; Gislason, 1993). This can be attributed to a higher average winter wind speed and by the fact that aerosol removal by snow is more efficient than by rain (Graedel and Franey, 1975). The average $\mathrm{pH}$ of integrated monthly samples of precipitation in 
southwestern Iceland from 1958 to 1981 presented by Gislason et al. (1996) was 5.4. More recent analyses (2008-2012) indicate that the average annual $\mathrm{pH}$ of rain ranged from 5.33 to 5.97 (Eiriksdottir et al., 2014b). For comparison, the $\mathrm{pH}$ of pure water saturated with atmospheric $\mathrm{CO}_{2}$ (395 ppmv; Keeling and Trans, 2016) at $25{ }^{\circ} \mathrm{C}$ equals to 5.56. Precipitation composition for the past several decades was reviewed in Stefánsson et al. (2017a).

The average, maximum and minimum $\mathrm{pH}$, conductivity and element concentrations of uncontaminated winter Langjökull snow samples collected annually during 1997 to 2006 are shown in Table 1 (data taken from Gislason et al., 2000; Eiriksdottir, 2008). In this study Langjökull snow will be used as reference snow for comparison with the 2014/2015 Vatnajökull snow samples collected in this study. In total, 30 snow samples were collected from 1997 to 2006: one sample during 1997 and 1998, two samples each year during 1999-2001 and three samples annually from 2002 to 2006. Similar to the cores collected in the present study, each sample represents the bulk average winter precipitation (September to March/April) at the sampling location. Note however, the geographical and geological settings of these samples are somewhat distinct from those of the present study (Fig. 1). The $\mathrm{pH}$ of the Langjökull snow samples ranged from 5.25-6.72 (average $\mathrm{pH}$ of 5.74). The average concentrations of major components were lower than those measured in rainwater collected closer to the Atlantic ocean as described above. The Vatnajökull snow samples collected during 1988 by Gislason (1990) had $\mathrm{pH}$ ranging from 5.45 to 5.91 (at room temperature) and concentrations of 7.61-22.1 for $\mathrm{Na}$, 0.13-1.41 for $\mathrm{K}, 0.13-2.13$ for $\mathrm{Na}, 0.29-2.22$ for $\mathrm{Mg}$, 3.66-25.6 for $\mathrm{Cl}, 0.44-4.18$ for $\mathrm{SO}_{4}$, and 1.64-4.10 for $\mathrm{HCO}_{3}$ (all in $\mu \mathrm{mol} / \mathrm{kg}$ ) which is mainly $\mathrm{CO}_{2}$ added during and after melting the snow samples.

Precipitation collected from monitoring stations all over Iceland during the Bárðarbunga eruption (Gislason et al. 2015; Stefánsson et al. 2017a) reveals that this eruption had major effect on the precipitation composition over an area of $100,000 \mathrm{~km}^{2}$ with the majority of the $\mathrm{SO}_{4}$ and $\mathrm{F}$ originating from volcanic gas emissions. In contrast to cations, which were relatively unaffected by this eruption, the concentrations of $\mathrm{F}$, and $\mathrm{SO}_{4}$ were about 20 and 3 times higher, respectively, compared to corresponding pre-eruption and recent Icelandic eruption samples (Stefánsson et al., 2017a).

\section{METHODS}

\subsection{Snow sampling}

Most of the sampling locations on Vatnajökull glacier (Fig. 1) have been chosen to match the locations of the annual snow balance measurements performed by the Institute of Earth Sciences, University of Iceland and the Landsvirkjun National Power Company (e.g. Björnsson and Pálsson, 2008; Pálsson et al., 2015). Samples T03, T05, and T08 were collected from the Tungnaárjökull glacier; samples D01, D02, D05, D07, D08, and D12 from the Dyngjujökull glacier; samples B09, B11, B13, B15, and BUDS from the Brúarjökull glacier; samples G01, 
G04, and BOR were collected from close to the Grímsvötn subglacial volcano. The M01, M02, and M03 samples were taken from the Maríutungur area (see Fig. 1). Names for samples collected outside the Vatnajökull glacier were taken from the geographical landmarks close to the sampling locations (e.g., Hornbrynja, Sauðahnjúkar, Kiðufell mountains).

After snow coring, the snow was collected into low-density polyethylene acid washed heavywalled 30-liter bags which had been previously washed with $1 \mathrm{M} \mathrm{HCl}$ and rinsed thoroughly with deionized (DI) water. The bulk snow samples weighed up to $14 \mathrm{~kg}$ and consisted of one to several drill cores depending on the depth of the snow cover. The length and weight and the physical properties of each core was measured in the field. To avoid contamination during the field characterisation, a second bulk sample was taken at each sampling site for the major and trace elements analysis. To assess the microbial community composition, cores from the T03, G04 and M03 sampling sites (Fig. 1) were collected into large sterile Whirl-Pak ${ }^{\circledR}$ bags for DNA sequencing. Two additional snow cores at D05 and M03 locations (Fig. 1) were collected and divided into 1 to $21 \mathrm{~cm}$ increments by cutting them with clean plastic knifes covered with a plastic bag if needed. Old layers' or 'summer layers' representing snow older than the 2014-15 winter precipitation were collected into separate bags. After sampling, all snow samples were packed into insulated boxes to ensure no melting occurred during their transport to the storage facility or laboratory. Prior to analyses samples were kept in a mobile freezer at $-24{ }^{\circ} \mathrm{C}$.

\subsection{Processing and snow sample analysis}

Snow cores for chemical analyses were melted at $60{ }^{\circ} \mathrm{C}$ for $20-40$ minutes depending on the snow volume. As soon as the snow was melted, it was processed as a regular water sample. Meltwater was filtered through $0.2 \mu \mathrm{m}$ Millipore cellulose acetate membranes using a peristaltic pump, pre-cleaned silicone tubing, and a $140 \mathrm{~mm}$ Sartorius ${ }^{\circledR}$ polytetrafluoropropylene filter holder. Acid washed high-density polypropylene bottles or vials, were used to collect samples for cation and trace metal analysis. Low- and high-density polyethylene bottles or vials, were used to collect samples for the other dissolved element measurements. Containers, acid washed with $1 \mathrm{M}$ $\mathrm{HCl}$, were used to collect samples for dissolved nutrient and dissolved organic carbon analysis. Water samples collected for major and trace metal analysis were acidified using Suprapur® 0.5 $\%(\mathrm{v} / \mathrm{v}) \mathrm{HNO}_{3}$. Amber glass bottles were used to collect filtered samples for $\mathrm{pH}$ measurements. Samples collected for dissolved organic carbon (DOC) were acidified with $1.2 \mathrm{M}$ concentrated $\mathrm{HCl} 2 \%(\mathrm{v} / \mathrm{v})$. Note that the snow sampling and analysis in this study does not allow the differentiation between the wet and dry soluble contributions to precipitation, and thus only the 'bulk' precipitation chemistry is obtained.

The $\mathrm{pH}$ of filtered samples was measured several hours after its melting at room temperature using an Oakton $\mathrm{pH}$ electrode. The dissolved inorganic carbon (DIC), $\mathrm{F}, \mathrm{Cl}, \mathrm{SO}_{4}, \mathrm{NO}_{3}$ were quantified using an ion chromatograph IC-2000 Dionex. Cations and trace metals, were measured using a Spectro Cirus Vision inductive coupled plasma, optical emission spectrometer (ICP-OES), with an in-house standard at the University of Iceland; precision was verified using the SPEX Certified Reference Standard. Most of the snow samples were also analysed by 
inductive coupled plasma sector field mass spectrometer ICP-SFMS at ALS Scandinavia, Luleå, Sweden. Dissolved organic carbon (DOC) was measured at the Umeå Marine Sciences Centre, Sweden by combustion and analysis as $\mathrm{CO}_{2}$ using a Shimadzu DOC-VPCH analyser. Samples for dissolved $\mathrm{PO}_{4}, \mathrm{NO}_{3}, \mathrm{NO}_{2}$, and $\mathrm{NH}_{4}$ were collected in high-density polypropylene vials and kept frozen until their colorometrical determination using an Alpkem AutoAnalyser. Samples for determination of nutrient concentrations were kept frozen at a temperature of $-18{ }^{\circ} \mathrm{C}$ from immediately after filtration until their analysis. Analytical measurements had inter-laboratory reproducibility within $5.0 \%$. Further details of the snow sampling and analysis (including $\delta^{34} \mathrm{~S}$ and DNA analyses) is presented in Chapter 4ES in the Electronic Supplement 2.

\subsection{PHREEQC calculations}

Aqueous speciation, charge balance, and mineral saturation states of melted snow collected during this study were calculated using the PHREEQC 2.17 geochemical code (Parkhurst and Apello, 1999) together with its phreeqc.dat database after its update with the aqueous complex formation and mineral solubility constants reported by Gysi and Stefánsson (2011). These caculations were performed using the measured samples compositions, $\mathrm{pH}$, and water temperature at time of melting provided in Tables 1 to 8 . The in situ $\mathrm{pH}$ and saturation states were calculated assuming the melting temperature of $0.1{ }^{\circ} \mathrm{C}$ and the DIC concentration as measured by ion chromatography. The fluid representing snow melt was not allowed to equilibrate with atmospheric $\mathrm{CO}_{2}$. The $\mathrm{pH}$ of the pure water at the temperature of 0.1 and $25^{\circ} \mathrm{C}$ was calculated assuming $\mathrm{CO}_{2}$ concentration of 395 ppmv (Tans and Keeling et al., 2016). The pH of pure water in equilibrium with this atmospheric $\mathrm{CO}_{2}$ concentration is 5.54 and 5.61 respectively at 0.1 and $25^{\circ} \mathrm{C}$.

To trace the origin of the dissolved volatiles, a non-reactive mixing between two fluids was calculated, based on the end-member fluid chemical and isotope composition and the corresponding mixing ratios. No chemical reactions were allowed during the mixing calculations. The mixing model applied in this study has previously been described by Stefánsson et al. (2017a). The PHREEQC reaction path modelling was used to evaluate the possible $\mathrm{pH}$ evolution of the rain water due to volcanic gas addition or interaction with rock aerosols. The initial fluid used in the model was rain water using the chemical composition reported by Stefánsson et al. (2017a). The basaltic material composition was similar to that used in Galeczka et al. (2014) with the exception of $\mathrm{S}$ and $\mathrm{Cl}$ concentrations which was taken from Kaasalainen and Stefánsson (2012). The composition of the volcanic plume was taken from Burton et al., 2016, Sigvaldason and Elíasson (1968) and Stefánsson et al. (2017b). In the first simulation the rain water was reacted incrementally with basalt in a closed system, and no secondary minerals were allowed to precipitate. In the second simulation, the rain water was reacted incrementally with the $\mathrm{SO}_{2(\mathrm{~g})}$ and $\mathrm{HCl}_{(\mathrm{g})}$ in proportions measured in the volcanic plume (Stefánsson et al., 2017b). Results of the

mixing calculations and reaction path modelling (rain water-basalt and rain water-volcanic gas 
interaction) were compared with the measured snow chemical composition to distinguish between rock and volcanic gas input (e.g., Gunnarsson-Robin et al., 2017).

\section{RESULTS}

The bulk samples collected in this study represent the weighted average chemical composition of the total snow layer accumulated at the sampling locations on Vatnajökull glacier (Fig. 1) from September 2014 until March 2015 (Table 2 and 3). The boundaries between the 2014-2015 accumulation and the previous years are rather obvious and include higher frequency of ice lenses of different sizes, different size of snow crystals and/or the presence of dust. Ice lenses are formed due to the partial melting of glacial snow in the summer and its subsequent refreezing in the autumn. Dust transported during the summer can be captured in the refreezing ice. Coarser snow crystals are present in the lower part of the layer between winter seasons (Gislason, 1990). The 2014-15 Bardarbunga eruption lasted 181 days, from August 31 to February 27. The first snow fell in the highlands NE of the glacier on September 6 (Pálsson et al., 2015; Icelandic Meteorological Office, IMO), indicating that snow samples collected during this study represents, apart from the first week, the entire eruption period. The uppermost part of the snow cores correspond to snow that fell after the eruption ended.

The D05 and M03 incremented cores were analysed to determine the chemical evolution of the snow as a function of depth, which can be translated to the time of snow accumulation (Tables 4 7). These samples are denoted D05_1 for the youngest and uppermost D05 increment (accumulated just before March, 23 when the sampling was performed) to D05_21 for oldest snow within the snow accumulation period at this sampling point. Beneath the D05_21 increment, the ice lenses formed due to spring/summer melt were found confirming the age of this sample.

Physical aspects and chemical compositions of the bulk snow and snow increments are presented in Table 2-6, in the Electronic Supplement 1 and Figs. 2-6. Figures 3 and 4 show depth of snow increments from the top to the bottom of the core, their names, lengths, and representative chemical compositions ( $\mathrm{pH}$ and $\mathrm{SO}_{4}$ ) within the D05 and M03 cores. The thickness of the winter layer and therefore length of the bulk cores reflect trends in precipitation and altitude. The northern part of Vatnajökull is within a "rain shadow", whereas its southern slopes are characterized with precipitation up to 7,000 mm water equivalent (Björnsson and Pálsson, 2008). The length of the bulk cores ranged from $75 \mathrm{~cm}$ (B09) to $634 \mathrm{~cm}$ (M03) with an average of 364 $\mathrm{cm}$. The longest cores (D12, G01, G04, BOR, B15, and M03) were sampled from the interior of the glacier and were more than $500 \mathrm{~cm}$ long. The amount of the 2014-15 winter precipitation on the Vatnajökull glacier varied; at the Dyngjujökull glacier, the winter precipitation equalled to $2.22 \mathrm{~m}$ water equivalents whereas within Grimsvötn-Gjálp area it equalled to $3.18 \mathrm{~m}$ water equivalents (Pálsson et al., 2015). The SE and SW wind carries most of the precipitation and the Holuhraun eruption site sits in the rain shadow from the Vatnajökull glacier (IMO, 2017). 
The chemical charge imbalance of the snow samples, calculated using the PHREEQC computer code was less than $5.2 \%$ (average $2.1 \%$ ) for bulk samples, 9.8\% (average $5.1 \%$ ) for the D05 increments, and $13.4 \%$ (average $3.1 \%$ ) for the M03 increments. The arithmetic average of the chemical concentrations of the D05 and M03 increments are presented below and in Table 1. The greatest charge imbalance was calculated for the 'summer/old layers' (see Table7). Those layers represent snow older than the 2014-2015 winter precipitation. It was sampled from beneath the bulk cores and it was characterized by coarser snow grains and/or ice lenses. Charge imbalance calculated for summer layers were as high as 36.9\% (average 13.6\%). This large charge imbalance is due to the dilute concentration of these layers; some chemical analyses were close to or below the detection limit. Lower concentrations in the summer layers stems from solute release during the partial melting of snow and lower sea spray effect due to lower wind speed in the summer time (Gislason, 1990; 1993; Eiríksdóttir, 2008).

The measured DIC might stem partly from the atmospheric $\mathrm{CO}_{2}$ dissolving in the meltwater during sample processing. There is no correlation between average density and lengths of the cores. There is positive correlation between the depth of the increments and their average density in core D05 $\left(\mathrm{R}^{2}=0.36\right)$. There is strong dependence of the density and depth of the increments for the $\mathrm{M} 03$ core with $\mathrm{R}^{2}=0.54$.

\subsection{The pH of the 2014-15 snow accumulated close to the eruption site}

The average measured $\mathrm{pH}$ at ambient temperature of the bulk samples, and the D05, and M03 increments were 5.08, 4.67, and 5.13, respectively. The measured $\mathrm{pH}$ distribution is shown in Fig. 2a. The isomaps presented in Fig. 2 are extracted from matrix surfaces (grids with $1000 \mathrm{~m} \mathrm{x}$ $1000 \mathrm{~m}$ meshes) and calculated from measured values using kriging interpolation with linear variogram using Golden Software, Surfer13 software. The difference between measured and in situ (the $\mathrm{pH}$ of the meltwater at $0.1{ }^{\circ} \mathrm{C}$ ) $\mathrm{pH}$ was 0.1 . The average $\mathrm{pH}$ of the D05 and M03 increments was close to that of the bulk snow samples D05 and M03; with a 4\% and $0.4 \%$ difference, respectively (Table 2, 4, and 6). At the Vatnajökull glacier, the lowest $\mathrm{pH}$ of 4.41 at $19.6^{\circ} \mathrm{C}$ was measured in D02 meltwater which core is located closest to the eruption site (Fig. 1 and 2) whereas the highest $\mathrm{pH}$ of 5.64 at $19.3{ }^{\circ} \mathrm{C}$ was measured in meltwater from B09 (774 m a.s.1.).

The pH of all the bulk samples other than T03, B09, Sauða 01, Kiðufell 01, Kiðufell 02, Pránd, and Oddskarð was below the $\mathrm{pH}$ range of the reference snow (5.25-6.73; Gislason et al., 2000). Note that the reference snow from Langjökull was affected by the 2000 Hekla and perhaps the 1998 and 2004 Grímsvötn eruptions (Flaathen and Gislason, 2008; Gislason et al., 2000).

Generally, the $\mathrm{pH}$ of the 2014-15 snow decreases with depth as exemplified in the D05 and M03 snow cores. All but three of the D05 increments were more acidic than the reference snow (Fig. $3)$. The lowest $\mathrm{pH}$ was measured in increment D05_17 (pH 4.05 at $\left.17.8^{\circ} \mathrm{C}\right)$. Similarly, most of the M03 increments $\mathrm{pH}$ values decrease with depth down to $300 \mathrm{~cm}$ (Fig. 4), but the correlation 
was not as strong as in the D05 increments. Below $300 \mathrm{~cm}$, the $\mathrm{pH}$ in the M03 core increased slightly followed by drop down to 4.52 at $550 \mathrm{~cm}$ depth. The majority of the increments were more acidic than the reference snow.

\subsection{Major and trace elements}

\subsubsection{Bulk snow samples}

The highest conductivity in the bulk samples was measured in the Hornbrynja core, $19.8 \mu \mathrm{S} / \mathrm{cm}$ and the lowest in B09, 3.6 $\mathrm{SS} / \mathrm{cm}$ (Fig.1 and Table 2). For comparison the average conductivity in one of the direct runoff rivers Fjarðará, which has catchments extending up to the Fjarðaheiði mountain pass (Fig. 1) in East Iceland, is $33 \mu \mathrm{S} / \mathrm{cm}$ (e.g. Eiriksdottir et al., 2013). The highest concentrations of volcanic components such as $\mathrm{SO}_{4}, \mathrm{~F}$ and $\mathrm{H}^{+}$were measured in cores D01, D02, D05, Hornbrynja, and Sauða 02 (Table 3) exceeding those concentrations in the reference snow. The $\mathrm{Cl}, \mathrm{Na}, \mathrm{Mg}, \mathrm{K}, \mathrm{NO}_{3}, \mathrm{NH}_{4}, \mathrm{~B}, \mathrm{Sr}$, and $\mathrm{Li}$ concentrations measured in bulk samples were within the range measured earlier in the reference snow. Concentrations of the metals $\mathrm{Al}, \mathrm{Fe}, \mathrm{Mn}$, $\mathrm{Ti}, \mathrm{Ba}, \mathrm{Cd}, \mathrm{Co}, \mathrm{Zn}, \mathrm{Mo}$, Ti and V exceeded those measured in the reference snow in cores D01, D02, B13, Sauða 02, and Hornbrynja. Other constituents including REE were slightly higher than those previously measured in the reference snow with the highest in the Dyngjujökull cores. In general, concentrations of dissolved sea-spray cations such as $\mathrm{Na}, \mathrm{K}, \mathrm{Mg}$, and $\mathrm{Sr}$ increase with increasing altitude in samples collected from the Vatnajökull glacier during this study, whereas this trend is not observed in the samples collected from the highlands northeast of the glacier. It is commonly observed that the sea spray effect on rain and snow composition decreases with distance from the sea and increasing altitude, however local topography can influence this effect (Gislason, 1990, 1993, 1996; Sigurdsson and Einarsson, 1988). A single storm can bring in high concentration of sea components inland and to high altitudes (Gislason, 1992).

Other components such as $\mathrm{NO}_{3}, \mathrm{NH}_{4}, \mathrm{~B}, \mathrm{Br}$, and I also increased with increasing altitude, whereas $\mathrm{Ca}, \mathrm{P}, \mathrm{Mn}, \mathrm{V}, \mathrm{Li}, \mathrm{Ba}, \mathrm{Cd}, \mathrm{Co}, \mathrm{Cr}, \mathrm{Cu}, \mathrm{Zn}, \mathrm{Hg}, \mathrm{Mo}, \mathrm{Ti}, \mathrm{Au}, \mathrm{Hf}, \mathrm{Nb}$ decreased with increasing altitude. The $\mathrm{pH}, \mathrm{Cl}, \mathrm{F}$, and $\mathrm{SO}_{4}$ did not show this trend. Snow cores from the lowest altitude in the highlands NE of Vatnajökull glacier were wet, indicating partial melting of the snow (Kiðufell 01 and 02, Oddskarð).

All but three summer layers (D01_SL_ice lens, D12_SL, and Hornbrynja_SL) had at least one constituent that was more concentrated compared to its corresponding bulk core (Table 7). The $\mathrm{SO}_{4} / \mathrm{Cl}$ ratios and $\mathrm{Al}$ and $\mathrm{F}$ concentrations in the summer layers compared to bulk cores can be seen in Figs. 2ES and 3ES, in Electronic Supplement 2. The summer layers D01_SL, D07_SL, G04_SL, M02_SL had only one chemical constituent more concentrated than in the corresponding bulk core. In contrast, the summer layers B09_SL_2, BUDS_SL, Sauða 01_SL_ice lens, Kiðufell 01 soil had at least 10 chemical constituents, including $\mathrm{K}, \mathrm{P}$, and $\mathrm{NO}_{3}$, more concentrated than in the corresponding bulk core. 


\subsubsection{D05 and M03 increments cores}

The variation with depth of $\mathrm{pH}$ and chemical compositions for core D05 are shown in Figs. 3 and 5 and Tables 4 and 5 and for core M03 in Figs. 4 and 6 and Table 6. These cores span from the beginning of the eruption to within 4 weeks after the end of the eruption. Generally, concentrations of most of the constituents including trace metals and REE $\left(\mathrm{SO}_{4}, \mathrm{~F}, \mathrm{Ca}, \mathrm{Al}, \mathrm{Fe}\right.$, Mn, Ti, $\mathrm{NO}_{3}, \mathrm{Mn}, \mathrm{As}, \mathrm{V}, \mathrm{Li}, \mathrm{Cd}, \mathrm{Co}, \mathrm{Cu}, \mathrm{Cr}, \mathrm{Pb}, \mathrm{Ni}, \mathrm{Zn}, \mathrm{Se}, \mathrm{Be}, \mathrm{Ag}, \mathrm{Bi}, \mathrm{Ga}, \mathrm{Ge}$, Ir, Nb, Os, Pd, Re, Sc, Sn, Te, Tl, U, Y, La, Ce, Pr, Nd, Sm, Eu, Gd, Tb, Dy, Ho, Er, Yb, Lu) increase with depth in the D05 core. Concentrations of most of the constituents exceeded concentrations measured in the reference snow in the lower part of this core (below $200 \mathrm{~cm}$ depth). In addition, there is more variation with depth in the chemical concentrations in the lower compared to the upper part of the core. Together with the lowest measured $\mathrm{pH}$, the highest concentration of several constituents was in increment D05_17.-In the M03 increments, seaspray constituents such as $\mathrm{Na}, \mathrm{Cl}, \mathrm{K}, \mathrm{Mg}$, $\mathrm{Sr}$ aremost concentrated down to $100 \mathrm{~m}$ in depth. The lower parts of the cores are generally depleted in these seaspray ions. The $\mathrm{Na}, \mathrm{Cl}, \mathrm{Mg}, \mathrm{K}$, and $\mathrm{Sr}$ show very similar patterns with the depth.

\subsection{Saturation states of the snow meltwater samples}

Meltwater samples are undersaturated with respect to all common primary and secondary minerals, hydrated basaltic glass and amorphous secondary minerals phases found in the weathering environment of basalt (Gysi and Stefánsson, 2011) at $0.1{ }^{\circ} \mathrm{C}$. The $p \mathrm{CO}_{2}$ of the melted snow samples were lower than atmospheric $p \mathrm{CO}_{2}$.

\subsection{Microbial community composition and cell numbers}

The results of the DNA sequencing of the T03 snow core are presented in Table 8. A total of 258 096 sequences passed the Qiime quality pipeline, corresponding to 591 operational taxonomic units clustered at $97 \%$ sequence identity. Proteobacteria was the most abundant phylum (94\%) with Gammaproteobacteria (92\%) being the overall dominant class and Pseudomonas (90\%) the overall dominant genus. Cyanobacteria was the second most abundant phylum (4\%) mainly being represented by the class Synechococcophycideae (3\%) and therein the genus Leptolyngbya $(2 \%)$.

The flow cytometry data for sample M03 and G04 showed 22735 and 24824 events respectively.

For M03 this corresponds to $3.4 \times 10^{5}$ cell $\mathrm{mL}^{-1}$ and $61.6 \%$ of the total events recorded, while for sample G04 this corresponds to $3.7 \times 10^{5}$ cells $\mathrm{mL}^{-1}$ and $30.4 \%$ of the total events recorded.

\subsection{Sulphur isotopes}

The sulphur isotope ratios for the snow and ice-core samples are listed in Table 3. The $\delta^{34} \mathrm{~S}_{\mathrm{SO}_{4}}$ ratios were +5.8 to $+16.6 \%$. These values range from those typically found for $\mathrm{SO}_{4}$ in waters 
draining basaltic terrains towards that of seawater (Torssander, 1986, 1989; Gislason and Torssander, 2006; Gunnarsson-Robin et al., 20170noet al., 2012; Rees et al., 1978).

\section{DISCUSSION}

\subsection{Controls on rain water and snow chemical composition in Iceland}

The chemical compositions of Icelandic precipitation has been monitored by the Icelandic Meteorological Office since 1958 (Eiríksdóttir, 2008; Gislason, 1990; IMO, 2017). Seaspray is the most abundant source of aerosols on land close to the oceans, whereas continental and manmade aerosols often dominate inland (Junge and Werby, 1958). Iceland is one of the most active dust sources on Earth with dust flux of 30-40 Mt/yr mainly coming from the glacier outwash planes, where the main component of the dust is basaltic glass (Arnalds et al, 2014). Dissolution of dust in rain water will increase $\mathrm{pH}$ and the concentrations of soluble rock forming constituents such as $\mathrm{SiO}_{2}, \mathrm{Ca}, \mathrm{Mg}, \mathrm{Na}$, and $\mathrm{K}$ depending on the dust chemical composition (Gislason and Eugster, 1997 a,b; Stefánsson et al., 2017a). Dust deposited with snow during winter will dissolve in meltwater during the spring, influencing the water chemical composition. Similar dissolution of volcanic gases and tephra (volcanic ash, mostly glass) in rain water changes rain, snow and meltwater compositions (e.g. Flaathen and Gislason 2007; Olsson et al. 2013). Volcanic $\mathrm{SO}_{2}$ hydrates and oxidizes in the atmosphere resulting in the formation of various sulphur species including sulphuric acid $\mathrm{H}_{2} \mathrm{SO}_{4}$ (Seinfeld and Pandis, 1988; Lelieveld, 1993; Stefánsson et al., 2017a). Volcanic gases and aerosols can be transported over long distances, affecting rain composition away from their sources as has been observed during previous eruptions in Iceland (Flaathen and Gislason, 2007; Gislason et al., 2015; Thordarson and Self, 2003). For example, the 2010 Eyjafjallajökull eruption resulted in increased F concentration in rain water $100 \mathrm{~km}$ from the eruption vent (Eiriksdottir et al., 2014a).

\subsection{Spatial and temporal evolution of chemical composition of the snow cover}

In general, snow collected from the Vatnajökull glacier and the highlands northeast of the glacier was more acidic and polluted than the reference snow (Table 1). During the 2014-15 Bárðarbunga eruption, volcanic gases and aerosols caused the $\mathrm{pH}$ of snow in the vicinity of the eruption vents to be as low as 3.3 (Gislason et al., 2015; Galeczka et al., 2016). The eruption also affected the chemical composition of the snow, as shown by much higher concentrations of halogens and metals than recorded in the reference snow (Gislason et al., 2015; Galeczka et al., 2016).

The $\mathrm{Na} / \mathrm{Cl}$ and $\mathrm{Mg} / \mathrm{Cl}$ ratio of Icelandic precipitation in the absence of volcanism has been shown to be close to that of seawater (Gislason et al. 1996). The ratio of major ions in the snow relative to chlorine compared to that of seawater confirms volcanic and perhaps anthropogenic effects on 
the snow chemistry (Fig. 7). Most of the D05 core increments and bulk samples exhibited an excess of $\mathrm{Cl}$ compared to seawater (Fig.7). Because of this $\mathrm{Cl}$ excess, the elemental ratios of seawater (element/Na; Bruland, 1983) and the measured $\mathrm{Na}$ concentration in snow were used in this study to correct for the seawater aerosol contribution in measured snow compositions. The $\mathrm{pH}$ was higher and the concentrations of $\mathrm{Na}, \mathrm{Mg}, \mathrm{Cl}$ were lower in 1988 Vatnajökull snow collected by Gislason (1990) compared to present study, even in samples collected at similar locations (samples T03, T05, T08). Note that the 1988 samples were collected in June, meaning that part of this snow deposited during the early spring months of April, May, and part of June, when the wind speed is on average lower than during the high-winter (e.g. Gislason et al. 1990, 2015). The highest $\mathrm{Cl}$ concentration in the present study was measured in T05 and Hornbrynja (Fig. 1). This is consistent with a prevailing South-East and South-West winds which bring marine aerosols from the south to the Tungnaárjökull glacier.

The dissolved $\mathrm{SO}_{4}$ concentrations were elevated in the BOR, Tungnaárjökull and Dyngjujökull cores and higher than in the Vatnajökull snow samples from 1988. Note however, that partial melting could explain some of the difference since the 1988 snow was collected in June and therefore spring melting could have flushed out some of the ions trapped in the snow (Gislason 1990; see chapter 6.5).

The most acidic snow samples were collected at Dyngjujökull with the lowest $\mathrm{pH}$ was in cores D01 and D02. Those cores are the closest to the eruption site indicating that volcanic activity affected most the areas located the closest to the eruption vent. The proximity of the volcanic plume source and its effect on snow chemical composition might have been intensified by the topography in the area. The base of the orographic clouds contains the majority of the pollutants compared to the upper part of the cloud and therefore the most polluted snow precipitated on lower slopes of the Dyngjujökull glacier (Dore et al., 1992, 1996; Nawrot et al., 2016). Predictions of the atmospheric $\mathrm{SO}_{2}$ distribution around Iceland during the eruption period based on the CALPUFF air quality model (Gislason et al., 2015) show, that atmospheric $\mathrm{SO}_{2}$ concentration was higher than $350 \mu \mathrm{g} / \mathrm{m}^{3}$ for $9-18$ of the eruption days and the highest concentrations were close to the eruption site. This is in contrast to what was seen in the rain water affected by the 2014-15 Bárðarbunga eruption, where the lowest measured pH was observed relatively far from the pollution source (about $100 \mathrm{~km}$ NE of the eruption site; Gislason et al., 2015; Stefánsson et al., 2017a). This observation was explained by the time and therefore distance needed for $\mathrm{SO}_{2}$ to oxidize and produce sulphuric acid (Gislason et al., 2015, Stefánsson et al., 2017a). Dry air oxidation rate of $\mathrm{SO}_{2}$ is a function of $\mathrm{UV}$ radiation and since the Bárðarbunga eruption occurred during the northern hemisphere winter, the UV radiation was low and the oxidation rate relatively slow (e.g. Flaathen and Gislason, 2007; Gislason et al., 2015). Oxidation in the close vicinity of the eruption vents is likely accelerated due to high temperature within the volcanic plume (Martin et al., 2006).

The strong correlation between uncorrected (Fig. 8) and seawater corrected (Fig. 9) $\mathrm{SO}_{4}, \mathrm{~F}$, and $\mathrm{Cl}$ concentrations and in situ $\mathrm{pH}$ confirms that aerosols originating from the volcanic $\mathrm{SO}_{2}, \mathrm{HCl}$, 
and $\mathrm{HF}$ acidified the snow. Note that in general there was insignificant amount of particulates in the snow samples, therefore, the dissolution of basaltic sediments containing low $\mathrm{Cl}, \mathrm{F}$, and $\mathrm{S}$ concentrations (e.g. Óskarsson, 1981) would not account for high concentrations of these constituents in snow samples. The stronger correlation for $\mathrm{Cl}$ than for $\mathrm{SO}_{4}$ concentrations versus in situ $\mathrm{pH}$ underscores the importance of $\mathrm{HCl}$ compared to $\mathrm{H}_{2} \mathrm{SO}_{4}$. This importance is likely due to higher $\mathrm{Cl}$ solubility and more rapid chemical pathways for $\mathrm{HCl}$ dissolution compared to $\mathrm{SO}_{2}$. This suggests that there is limited oxidation of $\mathrm{SO}_{2}$ apart from its initial high temperature oxidation since the eruption released 100 times more $\mathrm{SO}_{2}$ than $\mathrm{HCl}$ (Gislason et al. 2015). If all the seawater uncorrected $\mathrm{SO}_{4}, \mathrm{Cl}$, and $\mathrm{F}$ was assumed to be derived from $\mathrm{HCl}, \mathrm{HF}$ and $\mathrm{H}_{2} \mathrm{SO}_{4}$, the $\mathrm{pH}$ of the samples would be lower than that measured, as shown in Figure 10a. The calculated $\mathrm{pH}$, based on seawater corrected $\mathrm{SO}_{4}, \mathrm{Cl}$, and $\mathrm{F}$ concentrations are close to the in situ $\mathrm{pH}$ up to $\mathrm{pH} \sim 5$ (Fig. 10b). At neutral $\mathrm{pH}$, the calculated $\mathrm{pH}$ is higher than measured $\mathrm{pH}$ for the M03 core increments. This might stem from an overcorrection of the seaspray component for $\mathrm{Cl}, \mathrm{SO}_{4}$ and $\mathrm{F}$, or by the addition of volcanogenic $\mathrm{Na}$ in snow samples.

Hydrogen halides (Br, F, Cl, I) are highly soluble meaning that they are easily scavenged by rain or snow within hours to a few days, thus their effect on troposphere is local (Grellier et al., 2014). The seaspray constituents in the uppermost part of the M03 core are highly influenced by the changes of the wind direction and speed during the spring season and therefore the concentrations show considerable variation (Fig. 6).

Clearer correlations between $\mathrm{pH}$ and halogens are observed for the D05 than the M03 increments (Fig. 8 and 9). This is mainly due to the proximity of this sampling location to the eruption vent. Although the Maríutungur cores are further from the eruption site than the Dyngjujökull cores, they have also been affected by the volcanic activity as indicated by their increased $\mathrm{SO}_{4}$ concentration compared to $\mathrm{Cl}$. The $\mathrm{Cl}$ concentration in the Maríutungur cores is comparable to that of the Dyngjujökull cores, which have been the most affected by the volcanic eruption. Because the $\mathrm{SO}_{4}$ and $\mathrm{F}$ concentrations in seawater are lower than $\mathrm{Cl}$, the absolute concentrations of $\mathrm{SO}_{4}$ and $\mathrm{F}$ in snow influenced by volcanic plume are much more evident than for $\mathrm{Cl}$. The decrease in $\mathrm{pH}$ and increase in volcanic aerosols with depth reflects changes in effusion and emission rates throughout the volcanic eruption. The highest concentration of $\mathrm{SO}_{4}$ was observed in the increment with the lowest $\mathrm{pH}$ (D05_17). This snow precipitated during the first months of the eruption. In September and October, the effusion and emission rates were the highest (Gislason et al., 2015). Similarly, during the Laki eruption, most of the volatile mass ( $60 \%)$ was released during the first 1.5 months of the eruption (Thordarson et al., 1996).

The highest $\mathrm{pH}$ was measured in bulk core B09, which was relatively close to the eruption site. However, this sample had lower $\mathrm{SO}_{4}, \mathrm{Cl}$ and $\mathrm{F}$ concentrations than samples collected at Dyngjujökull (Table 3), and it also had greater amounts of embedded sediments (basaltic dust transported mostly from highlands). The dissolution of basalt increases meltwater $\mathrm{pH}$ (e.g. Gislason and Eugster 1987a; Galeczka et al 2014b). Similarly, a slightly higher pH compared to the glacier snow was observed in samples collected from the highlands northeast of the glacier. 
The lowest conductivity was found in core B09. Its conductivity of $3.6 \mu \mathrm{S} / \mathrm{cm}$ might be due to previous partial melting of this core at its relative low altitude (774 m.a.s.1.) and geographical setting - the sample spot might have been protected by the Kverkfjöll mountain range (Fig. 1).

As can be seen in Fig. 11, protons $\left(\mathrm{H}^{+}\right)$balanced about half of the negatively charged anions in the bulk D05 core, $\sim 10 \%$ in the bulk M03 core and $\sim 70 \%$ in the most polluted sample, the D05_17 increment. Also this increment had the highest contribution of $\mathrm{SO}_{4}$ into charge balance. The dominating anion in all snow samples was $\mathrm{Cl}$, which mostly originates from seaspray. The seaspray contribution was the highest in samples least affected by the volcanic eruption (e.g. M03 as seen on Fig. 7) confirming seaspray as main source of the dissolved ions in these samples. The contribution of non-marine cations, such as $\mathrm{Al}$ and Fe, increases in samples which were the most affected by the volcanic gases and/or aerosols.

The concentrations of Al, Fe, Mn, V, As, Ba, Cd, Co, Cr, Cu, Pb, Se, Ti, Ag, Pd, Re, Te, Tl, Y, and all REE were highest in the cores from Dyngjujökull (Fig. 1); most often the highest values were found in cores D01 or D02 (Table 3). The Al, Fe, Cu, Pb, Se, Ti, Ag, Pd, Re, Te, Tl, Y, and all REE show positive correlations with the sum of $\mathrm{SO}_{4}, \mathrm{Cl}$, and $\mathrm{F}$ with $\left(\mathrm{R}^{2}>0.5\right)$ suggesting that these elements were degassed at depth and transported in the gas phase of the eruption as chlorides, fluorides and/or sulphate aerosols/salts (e.g. Moune et al., 2006; Gauthier et al., 2016). Most metal concentrations also increased with decreasing $\mathrm{pH}$, confirming their addition due to volcanic acidic gases. The positive correlation between metals e.g. Al which is refractory with volcanogenic ions suggests transport of these metals within the plume; in this case $\mathrm{Al}$ as fluoride and chloride species (Calabrese et al., 2011). In addition, the concentration of particulates was low in the snow samples; no correlation between $\mathrm{pH}$, metal concentration or particulate concentration was found, confirming insignificant effect of basaltic particle dissolution into the ion budget. Note, that although the snow cores were melted at around $60{ }^{\circ} \mathrm{C}$ the meltwater temperature was close to $0{ }^{\circ} \mathrm{C}$ right after melting, and the contact time between particles and meltwater before its filtration was short (less than an hour). Dissolution rates of basaltic glasses decrease with decreasing temperature (Gislason and Oelkers, 2003). The $\mathrm{SiO}_{2}$ concentration was very low in all the melted snow samples, confirming the insignificant contribution of basaltic particle dissolution on the chemical composition of the snowmelt.

The compositions of all elements in all snow samples, apart from some of the incremental samples, were within European drinking water standards (European Community, 1998). The D05 increments from near the bottom of the core exceeded the limits for Al given by World Health Organization (WHO, 2006). Snow collected in vicinity of the eruption site during the 2014-15 Bárðarbunga eruption was acidic, with $\mathrm{pH}$ ranging from 3.34 to 4.85, and with $\mathrm{F}, \mathrm{Al}, \mathrm{Fe}, \mathrm{Mn}, \mathrm{Cd}$, $\mathrm{Cu}$, and $\mathrm{Pb}$ concentrations surpassing drinking water standards (Galeczka et al. 2016; Gislason et al., 2015; European Community, 1998).

The major hazard related to snow acidification is proton and metal mobility. Metal mobility increases with decreasing $\mathrm{pH}$ and acidic snowmelt will increase dissolution of particles embedded in the snow/ice and the bedrock, potentially provoking further toxic metal release. 
Kepski et al. (2016) reported that more than half of pollutants in snow were released with the first $14 \%$ of the snow melt. Partial melting of snow can result in factor of five concentration increase in the initial meltwaters (Johnnessen and Henriksen, 1978; Gislason, 1990). Taking as an example the bulk sample D02 and its in situ pH of 4.41 (Table 2), the partial melting would decrease the meltwater $\mathrm{pH}$ to about 3.7 (calculated by multiplying the proton activity by factor of 5). Similarly, the initial melt from the all the bulk samples with an average in situ $\mathrm{pH}$ of 5.09 could be as low as 4.4. This decrease of $\mathrm{pH}$ would increase the solubility of the solid $\mathrm{Al}(\mathrm{OH})_{3}$ a factor of 3 .

It should be pointed out however that some of the negative environmental impacts of snow acidification are attenuated by water-rock interaction. Thd increased host rock dissolution caused by acidic snowmelt can mobilize the elements limiting biological activity such as $\mathrm{Fe}$ (White, 1999) ,. Moreover, the acidic snow meltwater will precipitate toxic metal scavenging (oxy)hydroxides as mineral-fluid reactions neutralize the acidic waters (Aiuppa et al., 2000a,b, Flaathen and Gislason, 2007, Flaathen et al., 2009). Note also that the fluoride sourced from volcanic HF and F salts will increase basalt dissolution rates (Wolff-Boenisch et al., 2004) further accelerating the neutralization of the acidic snowmelt.

\subsection{Temperature, partial melting, and constituent fractionation with depth}

The concentrations of most ions increase with depth in core D05; this increase is more pronounced after correcting these concentrations for seawater input. It seems likely that this increase is related to the intensity of the volcanic emissions and effusion rates. This trend is not seen for ions of marine origin, such as $\mathrm{Na}$ (Fig. 5). Air temperature measurements carried out by the IMO on the Brúarjökull glacier (see the weather station location in Fig. 1) indicate that the first drop of temperature below $0{ }^{\circ} \mathrm{C}$ was at the end of September 2014 and the temperature remained below $0{ }^{\circ} \mathrm{C}$, with the coldest period from February until April (Fig. 4ES in Electronic Supplement 2). From the end of September until April, there were short periods when the temperature increased above $0{ }^{\circ} \mathrm{C}$ possibly leaving thin ice lenses in the snow. Higher concentrations of ions in the summer layers of the snow in the vicinity of Brúarjökull (B09, B15, BUDS; Table 7) confirms that it might have partially melted during the winter. Partial melting tends to flush ions out from the snow into the meltwater. Most of the salts, aerosols, and pollutants are present on the surface of the snow crystal and thus readily removed by meltwater (Gislason, 1990; Johannessen and Henriksen, 1978). The concentration of several ions in the summer layers collected from the highlands were higher than the corresponding bulk snow samples, suggesting partial melting. In general, most of the summer layers are dilute comparing to bulk snow, however, the $\mathrm{SO}_{4} / \mathrm{Cl}$ ratio in the summer layers is often higher than the bulk snow samples (Fig. 2ES in Electronic Supplement 2). Note, that due to physical and chemical properties, $\mathrm{Cl}$ is released faster than $\mathrm{SO}_{4}$ due to its larger hydrated radii (Gislason, 1990). 


\subsection{Volatile concentrations in the snow and in the volcanic plume}

The molar ratios of volatile components in the snow samples were substantially different than that of the plume. The average bulk snow $\mathrm{S} / \mathrm{Cl}$ ratio is closer to that of seawater than to that of the plume. The $\mathrm{S} / \mathrm{Cl}$ and $\mathrm{F} / \mathrm{Cl}$ molar ratios in the plume were 55 and 0.9 , respectively (Gislason et al., 2015; Stefánsson et al. 2017a), whereas these ratios in seawater are 0.05 and $1.24 \times 10^{-4}$, respectively (Bruland, 1983). The average bulk snow molar ratios are equal to $0.09 \mathrm{for} \mathrm{S} / \mathrm{Cl}$ and 0.01 for $\mathrm{F} / \mathrm{Cl}$. The highest ratios in the D05 increments were 0.7 and 0.2 for $\mathrm{S} / \mathrm{Cl}$ and $\mathrm{F} / \mathrm{Cl}$, respectively. The seawater corrected ratios are an order of magnitude higher. Nevertheless, they are always lower than the gas plume ratios. Although the snow chemical ratios are lower than the plume ratios, comparison between the seawater derived and total $\mathrm{S}, \mathrm{Cl}$, and $\mathrm{F}$ concentrations in the bulk and D05 increments, after the sodium correction as described earlier, indicates that up to $96 \%$ of $\mathrm{SO}_{4}$, up to $70 \%$ of the $\mathrm{Cl}$, and up to $100 \%$ of the $\mathrm{F}$, was sourced by the volcanic plume. In this estimation, due to small amount of basaltic dust in the snow samples, and the low concentration of these components in basaltic glass, rock derived $\mathrm{S}, \mathrm{Cl}$, and $\mathrm{F}$ were neglected. In addition, the volume of tephra produced during this eruption was not substantial (Gudmundsdottir et al., 2016). All collected snow samples had $>90 \%$ of F derived from volcanic plume. Majority of the samples (54\%) had more than half of the total S sourced from volcanic aerosols. Calabrese et al. (2011) observed that the rainwater in vicinity of Etna volcano reflected the composition of the volcanic plume and concluded that element fractionation occurs during the scavenging of plume-derived elements. The relative concentrations of these volatiles in the plume compared to the snow demonstrates that $\mathrm{Cl}$ and $\mathrm{F}$ are much more efficiently taken up by snow surfaces than S.

Further insight into the origin of volatile elements in the Vatnajökull snow was gained from sulphur isotope $\delta^{34} \mathrm{~S}$ fractionation, mixing models and reaction path simulations (Fig. 12). The ${ }^{34} \mathrm{~S}$ isotope composition of the snow collected during this study indicates that the seawater ${ }^{34} \mathrm{~S}$ signal $\left(\delta^{34} \mathrm{~S}\right.$ of $21 \%$; e.g. Marini et al., 2011) decreased with the distance from the shore. Snow collected closest to the eruption site was the most depleted in $\delta^{34} \mathrm{~S}$ compared to seawater. This is consistent with the greater seawater $\mathrm{Cl}$ and $\mathrm{Na}$ concentrations in the snow closer to the shoreline. The calculated $\delta^{34} \mathrm{~S}$ fractionation obtained from the non-reactive mixing of unpolluted rainwater of marine origin with basalt and volcanic gas, respectively, results in similar trends - the depletion of $\delta^{34} \mathrm{~S}$ (Fig. 12a). In general, the $\delta^{34} \mathrm{~S}$ composition of samples collected during this study, and in vicinity of the Holuhraun lava (Galeczka et al., 2016), compares better when the volcanic gas rather than basalt is mixed with the rain water. The $\mathrm{pH}$ versus $\delta^{34} \mathrm{~S}$ of the rain water and basalt and rain water and volcanic gas interaction show distinct trends (Fig. 12b). With the decreasing $\delta^{34} \mathrm{~S}$, the $\mathrm{pH}$ of the modelled fluid increases from the initial $\mathrm{pH}$ of 5.7 when basalt is disolved in the rain water whereas the $\mathrm{pH}$ decreases when volcanic gas is dissolved. Comparison of those trends with the chemical composition of the snow connfirms the presence of volcanically derived $\mathrm{S}$ in the snowmelt. 


\subsection{Enrichment ratios of the volatiles and trace metals in the Vatnajökull snow}

The enrichment factor (EF) indicates the enrichment or depletion of a given element in snow relative to the volcanic plume. This was calculated by dividing snow concentration ratio of the element of interest normalized to a reference element, by the same concentration ratio in the volcanic plume. Following Gauthier et al. (2016), $\mathrm{Mg}$ was used as normalizing element in this study. Trace and volatile element concentrations in the plume were taken from Gauthier et al. (2016). As can be seen in Fig. 13, all "volatile" elements were depleted in the snow relative to the plume with the greatest depletion for S. Similar trends were found in the most acidic snow collected close to the Holuhraun lava (Galeczka et al., 2015). As such, S is least efficiently snow trapped volatile element in the near vicinity of the Bárðarbunga volcanic eruptions. The least depleted element in the snow relative to the plume was Se. Similar, Se was found as one of the most enriched elements in the plume relative to the Holuhraun lava (Gauthier et al., 2016). The $\mathrm{Se}$ is an essential element for the biota, however, it can be toxic if concentrations exceed acceptable limits. Volcanogenic Se is mobile due to its relatively low vaporization temperature. Oxidation and cooling processes in the atmosphere will transform Se to soluble selenite $\left(\mathrm{SeO}_{3}{ }^{2-}\right)$ and selenate $\left(\mathrm{SeO}_{4}{ }^{2-}\right)$ (Wen and Carignan, 2007) resulting in its high concentrations in the plume and therefore in snowfall and rainfall (Floor et al., 2011). Low amounts of Se have been found in Icelandic hay and herbage (Eiríksdóttir et al. 1981, Símonarson et al. 1984) resulting in Se deficiency occurring ubiquitously in lambs (Jóhannesson et al., 2007). Melting of snow enriched in Se might increase Se fluxes into to the surface waters and therefore making it available for biota. The relative enrichment factor of major cations and anions in precipitation relative to $\mathrm{Cl}$ and seawater was calculated by Stefánsson et al. (2017a). They shows that the $\mathrm{SO}_{4}$ and $\mathrm{F}$ were greatly enriched in the precipitation compared to seawater suggesting that these volatiles were sourced from gas emission in addition to seawater spray.

\subsection{The influx of chemical components on Vatnajökull glacier}

The deposition fluxes of specific elements on the surface of Vatnajökull glacier were calculated using chemical concentrations of the snow cores collected on the glacier, their weights and dimensions, and the time of the snow accumulation; in this case the time from the first snowfall to the snow sampling was assumed to be six months. The term 'flux' represents the mass of the specific constituents deposited with the snow onto the glacial surface over a specific period of time, in $\mathrm{mg} / \mathrm{m}^{2} /$ month.. The volatile fluxes distribution over the studied area are shown in Fig. 2 $\mathrm{b}, \mathrm{c}, \mathrm{d}$. The average fluxes of volatiles corrected for seaspray addition were 25.5 for $\mathrm{S} ; 75.2$ for $\mathrm{Cl}$, and 3.7 for $\mathrm{F}$; all in $\mathrm{mg} / \mathrm{m}^{2} /$ month. The average seawater uncorrected $\mathrm{S}$ and $\mathrm{Cl}$ fluxes were within the range measured earlier at the Mjóanes rain monitoring station in SW-Iceland (Eiriksdottir et al., 2014a; Eiriksdottir and Sigurdsson, 2014b). In contrast, the F flux on Vatnajökull glacier was almost 4 times higher than at the Mjóanes station. Note, that Mjóanes location (Fig. 1) is distinct from that of the Vatnajökull glacier and therefore the effect of seaspray, dust and other local variabilities on precipitation differs. In addition, Mjóanes precipitation is affected by geothermal 
activity (Eiriksdottir et al., 2014a; Eiriksdottir and Sigurdsson, 2014b). Despite these differences, due to lack of more recent data, the Mjóanes element fluxes were used for this comparison. The S fluxes exceeded those calculated for Mjóanes in the cores collected closest to the eruption site (all Dyngjujökull cores), whereas F fluxes were higher in all but the M01 core. The highest S and F fluxes were calculated for core D01 (Fig. 2 b,c,d). This confirms the effect of the proximity of the eruption site on the monthly fluxes of volcanogenic volatiles. Due to lack of data on the intensity of snowfall with time, the deposition rates of the elements were not calculated. The volatile concentrations in the Vatnajökull snow were within the range of those measured in rain collected at IMO monitoring stations from September 2014 until February 2015 (Stefánsson et al., 2017a). However, the maximum rain concentrations are considerably higher than the highest concentrations measured in the snow samples collected in this study. Note, that the most acidic rain water was found at more distal locations than the snow samples collected during this study, suggesting low temperature oxidation of $\mathrm{SO}_{2}$.

\subsection{Microbial community composition}

Sufficient DNA for sequencing identification was only obtained from core T03, and average cell numbers were determined in snow from samples G04 and M03. The average cell numbers evaluated by flow cytometry $\left(\sim 10^{5} \mathrm{~mL}^{-1}\right)$ were in the range of previously reported values for spring and summer snow (Amato et al., 2007; $10^{3}-10^{5}$ cells $\mathrm{mL}^{-1}$ ). The sequencing showed that in core T03, the most abundant genus was Pseudomonas, which belongs to the Proteobacteria phylum within the Bacteria domain. The Pseudomonas species are known as plant pathogens and for their ice-nucleating capacities (Morris et al., 2010). While Pseudomonas taxa are widespread in many environments, they were also described as present, yet not dominant in Greenland and Svalbard spring snow after fresh deposition (Larose et al., 2010; Cameron et al., 2015). In Iceland, samples of summer snow collected during June to August of 2012 to 2014 (Lutz et al., 2015), revealed also a dominance of Proteobacteria (however mostly Betaproteobacteria and not Pseudomonas) early in the melting season, and Bacteroidetes later in the melting season. Although, both in core T3 and the summer snow described in Lutz et al. (2015) the bacterial community was dominated by the Proteobacteria phylum, it is important to note that at the genus level the differences are substantial. The main reason for this is likely because the microbial biomass in summer snow across the Artic is dominated by cosmopolitan snow algae, while the bacteria are a smaller part of the biomass (Lutz et al., 2016, 2017). We found that Pseudomonas dominated in core sample T03. Among the genus Pseudomonas, the species Pseudomonas syringae is known to be an ice nucleating bacteria and thus it is possible that by inducing the freezing of atmospheric water droplets, these ultralight bacteria, actively enhance snow deposition (Morris et al., 2008), explaining their high abundance in the freshly deposited snow. As Pseudomonas is widespread in freshly deposited snow (Larose et al., 2010; Cameron et al., 2015), it appears that the high amounts of aerosols created by the 2014-15 Bárðarbunga eruption did not substantially affect the microbial community composition in our snow samples. 


\subsection{Scavenging potential}

The average depositional flux calculated for sampling sites (see Chapter 6.6) located within the specific Vatnajökull glacier outlets and their respective areas (Fig. 1; Pálsson et al., 2015) were used to estimate the total $\mathrm{S}, \mathrm{Cl}$, and $\mathrm{F}$ deposition flux during the winter. The omparison between these fluxes and the total mass of $\mathrm{S}, \mathrm{Cl}$, and $\mathrm{F}$ released during the eruption period was used for estimating the snow scavenging potential of the volatiles. The total mass of S deposited within the accumulated winter snow was: 293 tonnes at Dyngjujökull glacier, $163 \mathrm{t}$ at Brúarjökull, $25 \mathrm{t}$ at Tungnaárjökull, $24 \mathrm{t}$ in Grímsvötn area, and $9 \mathrm{t}$ at Maríutungur. The total mass of $\mathrm{Cl}$ was 1130 $\mathrm{t}$ at Dyngjujökull glacier, $375 \mathrm{t}$ for Brúarjökull, $54 \mathrm{t}$ at Tungnaárjökull, $64 \mathrm{t}$ in Grímsvötn area, and $16 \mathrm{t}$ at Maríutungur. Finally, the total mass of $\mathrm{F}$ was $42 \mathrm{t}$ at Dyngjujökull glacier, $16 \mathrm{t}$ at Brúarjökull, $5 \mathrm{t}$ at Tungnaárjökull, $4 \mathrm{t}$ in Grimsvötn area, and $1 \mathrm{t}$ for Maríutungur. Although the greatest mass of deposited volatiles was found in the snow accumulated at Dyngjujökull, it scavenged only $0.005 \%, 1.16 \%$, and $0.09 \%$ of total $\mathrm{S}, \mathrm{Cl}$, and $\mathrm{F}$ released during eruption period, respectively. This observation confirms that the deposition and scavenging potential close to the eruption site (up to several tens of $\mathrm{km}$ ) was minor compared to the mass of emitted gas. It also suggests that residence time of gases/aerosols in the atmosphere is long. Similarly, Calabrese et al. (2011) found that more than $90 \%$ of volcanogenic trace elements were dispersed to at least 10 $\mathrm{km}$ from the volcanic source and only $0.05-0.5 \%$ of $\mathrm{S}, 0.1-1.1 \%$ of $\mathrm{Cl}$, and $0.05-0.3 \%$ of $\mathrm{F}$ released to the atmosphere was deposited within $10 \mathrm{~km}$ distance from the summit. Moreover, the higher scavenging of $\mathrm{Cl}$ compared to $\mathrm{S}$ in our studies samples is consistent with the conclusion that substantial distance is needed for $\mathrm{SO}_{2}$ to oxidize and produce sulphuric aerosols which is favourable to uptake by snow (Gislason et al., 2015, Stefánsson et al., 2017a). Taken together, these observations also suggest that although snow cores preserve volcanic signals and therefore can be useful to identify past volcanic events, due to the minor scavenging potential of this snow and partial melting, detailed chemical composition of past volcanic plume cannot be obtained from the analysis of historic snowfalls.

\section{CONCLUSIONS}

There are several major conclusions that can be drawn from this study on the chemical composition of the snow deposited during the 2014-15 Bárðarbunga eruption:

1. Despite the fact that 2014-15 Bárðarbunga eruption was the largest eruption around the NorthAtlantic in more than 200 years, the toxic and heavy metals concentrations of its surrounding snowpack did not exceed drinking water standards given by European Commission (EC, 1998).

2. Environmental impact of the volcanic eruptions varies with time. The highest gas emission and

lava effusion rates were measured during first weeks of the eruption (Gislason et al., 2015). This 
was reflected by the highest acidity and metal contamination of the deepest and oldest part of the snow cores.

3. The highest concentrations of volatiles in the snow cores were found close to the eruption site on the Dyngjujökull glacier. This confirms the results of the $\mathrm{SO}_{2}$ gas dispersion CALPUFF air quality model (Gislason et al., 2015) which predicted that the same area would be one of the most affected by the volcanic plume.

4. Proximity of the rich in $\mathrm{SO}_{4}$ snow cores to the eruption site confirms that the $\mathrm{SO}_{4}$ was probably sourced from the high temperature $\mathrm{SO}_{2}$ oxidation within the volcanic plume. Otherwise, the highest $\mathrm{SO}_{4}$ concentrations would have been expected in the snow cores further away from the eruption site, similar to what was found in the rain water samples (Stefánsson et al., 2017a).

5. The snow scavenging potential close to the eruption site (up to several tens of $\mathrm{km}$ ) was minor. The snow removed only up to $1.2 \%$ of $\mathrm{Cl}$, less than $1 \%$ of $\mathrm{F}$, and less than $1 \%$ of total $\mathrm{S}$ released during the entire eruption period. It confirms that the snow has limited cleaning capability of the volcanic pollutants from the air. It also confirms long life-time of volcanic volatiles in the atmosphere.

6. The microbial communities were similar to those found in other parts of the Arctic, confirming a minor impact of this eruption on the microbial ecology within the snow.

\section{Acknowledgements}

This study was funded by Ríkislögreglustjórinn Almannavarnadeild - The National Commissioner of the Icelandic Police, Jarðvísindastofnun Háskólans - Institute of Earth Sciences University of Iceland and Veðurstofa Íslands - IMO, and Rannsóknamiðstöð Íslands - The Icelandic Centre for Research RANNÍS (Grant \# 163531-051). The authors would like to thank to all of those who helped to organize the field trip. Special thanks to Porsteinn Jónsson and Hlynur Skagfjörð Pálsson - without them snow collection would have been impossible. We also thank all the colleagues and co-workers from Institute of Earth Sciences and IMO for fruitful discussions during the time of the Bárðarbunga unrest. In addition, LGB and SL would like to acknowledge financial support for the microbiological work from the German Helmholtz Recruiting Initiative Fund. 


\section{References}

Aiuppa, A., Dongarrà, G., Capasso, G., Allard, P., 2000a. Trace elements in the thermal groundwaters of Vulcano Island (Sicily). J. Volcanol. Geotherm. Res. 98: 189-207.

Aiuppa, A., Allard, P., D’Alessandro, W., Michel, A., Parello, F., Treuil, M., Valenza, M., 2000b. Mobility and fluxes of major, minor and trace metals during basalt weathering and groundwater transport at Mt. Etna volcano (Sicily). Geochim. Cosmochim. Acta 64: 18271841.

Aiuppa, A., Bellomo, S., Brusca, L., D'Alessandro, W., Di Paola, R., Longo, M., 2006. Major-ion bulk deposition around an active volcano (Mt. Etna, Italy). Bull Volcanol. 68: 255-265.

Aiuppa, A., Franco, A., von Glasow, R., Allen, A.G., D'Alessandro, W., Mather, T.A., Pyle, D.M., Valenza, M., 2007. The tropospheric processing of acidic gases and hydrogen sulphide in volcanic gas plumes as inferred from field and model investigations. Atmos. Chem. Phys. 7: 1441-1450.

Aiuppa, A., 2009. Degassing of halogens from basaltic volcanism: Insights from volcanic gas observations. Chem. Geol. 263: 99-109.

Alt, J.C., Shanks, W.C., 1998. Sulphur in serpentinized oceanic peridotites: serpentinization processes and microbial sulfate reduction. J. Geophys. Res. 103: 9917-9929.

AMAP 1998. Assessment Report: Arctic Pollution Issues. Oslo, Norway: Arctic Monitoring and Assessment Programme, 859 pp.

Amato, P., Hennebelle, R., Magand, O., Sancelme, M., Delort, A-M., Barbante, C., Boutron, C., Ferrari, C., 2007. Bacterial characterization of the snow cover at Spitzberg, Svalbard. FEMS Microbiol. Ecol. 59: 255-264.

Andronache, C., 2004. Estimates of sulfate aerosol wet scavenging coefficient for locations in the Eastern United States. Atmosph. Environ. 38: 795-804.

Arason, P., Bjornsson, H., Petersen, G. N., Jónasdóttir, E. B., Oddsson, B. B., 2015. Plume height during the 2014-2015 Holuhraun volcanic eruption. Geophys. Res., Abstracts, EGU201511498.

Arnalds, O., Olafsson, H., Dagsson-Waldhauserova, P., 2014. Quantification of iron-reach volcanogenic dust emissions and deposition over ocean from Icelandic dust sources. Biogeosci. Discussion 11: 5941-5967.

Bagnato, E., Aiuppa, A., Bertagnini, A., Bonadonna, C., Cioni, R., Pistolesi, M., Pedone, M. Hoskuldsson, A., 2013. Scavenging of sulphur, halogens and trace metals by volcanic ash: The 2010 Eyjafjallajökull eruption. Geochim. Cosmochim. Acta 103: 138-160.

Bekki, S., 1995. Oxidation of volcanic $\mathrm{SO}_{2}$ : A sink for stratospheric $\mathrm{OH}$ and $\mathrm{H}_{2} \mathrm{O}$. Geophys. Res. Lett. 22: 913-916. 
Berner, E.K., Berner, R.A. 1996. Global environment: Water, air and geochemical cycles. Engelwood Clifts, New Jersey, Prentice Hall.

Björnsson, H. 1988. Hydrology of Ice Caps in Volcanic Regions. Soc. Sci. Isl. 45, Reykjavik, $139 \mathrm{pp}$.

Björnsson, H., 1998. Hydrological characteristics of the drainage system beneath a surging glacier. Nature 395: 771-774.

Björnsson, H., Pálsson, F., Guðmundsson, M.T., Haraldsson H.H., 1998. Mass balance of western and northern Vatnajökull, Iceland, 1991-1995. Jökull, 45: 35-38.

Björnsson, H., Pálsson, F., Haraldsson, H.H., 2002. Mass balance of Vatnajökull (1991-2001) and Langjökull (1996-2001), Iceland. Jökull 51: 75-78.

Björnsson, H., 2003. Subglacial lakes and jökulhlaups in Iceland. Global and Planetary Change 35: $255-271$.

Björnsson, H., Einarsson, P., 1990. Volcanoes beneath Vatnajökull, Iceland: Evidence from radio echo-sounding, earthquakes and jökulhlaups. Jökull 40: 147-168.

Björnsson, H. and Pálsson, F., 2008. Icelandic glaciers. Jökull, 58: 365-386.

Bobrowski, N., von Glasow, R., Aiuppa, A., Inguaggiato, S., Louban, I., Ibrahim, O.W., Platt, U., 2007. Reactive halogen chemistry in volcanic plumes. J. Geophys. Res.: Atmosph. 112: 1-17.

Boutron, C.F., Görlach, U., Candelone, J.P., Bolshov, M.A., Delmas, R.J., 1991. Decrease in anthropogenic lead, cadmium and zinc in Greenland snows since the late 1960s. Nature 353: $153-156$.

Boutron, C.F., Vandal, G.M., Fitzgerald, W.F., Ferrari, C.P., 1998. A forty year record of mercury in central Greenland snow. Geophys. Res. Lett. 25: 3315-3318.

Bruland, K.W., 1983. Trace elements in seawater. In: Chemical oceanography. Riley, J.P. and Chester, R. (Editiors), 8: 157-220. Academic Press London, London.

Budhavant, K.B., Prakasa Rao, P.S., Safai, P.D., 2014. Chemical Composition of Snow-Water and Scavenging Ratios over Costal Antarctica. Aerosol Air Quality Res. 14: 666-676.

Burton, M., Ilyinskaya, E., Spina, A.L., Salerno, G., Bergsson, B., Donovan, A., Barsotti, S., Pfeffer, M., 2015. Contrasting gas composition and fluxes produced by the Holuhraun 201415 eruption and Fimmvörduháls 2010 eruption, Iceland. Geophys. Res., Abstracts, EGU201515899.

Calabrese, S., Aiuppa, A., Allard, P., Bagnato, E., Bellomo, S., Brusca, L., D’Alessandro, W., Parello, F., 2011. Atmospheric sources and sinks of volcanogenic elements in a basaltic volcano (Etna, Italy). Geochim. Cosmochim. Acta 75: 7401-7425. 
Cameron, K.A., B. Hagedorn, M. Dieser, B.C. Christner, K. Choquette, R. Sletten, B. Crump, C. Kellogg, K. Junge. 2015. Diversity and potential sources of microbiota associated with snow on western portions of the Greenland Ice Sheet. Environ. Microbiol. 17: 594-609.

Candelone, J.P., Hong, S., Pellone, C., Boutron, C.F., 1995. Industrial revolution changes in large scale atmospheric pollution of the Northern Hemisphere for heavy metals as documented in central Greenland snow and ice. J. Geophys. Res. 100: 16,605-16,616.

Caporaso, J.G., Kuczynski, J., Stombaugh, J., Bittinger, K., Bushman, F.D., Costello, E.K., Fierer, N., Gonzalez Peña, A., Goodrich, J.K., Gordon, J.I., Huttley, G.A., Kelley, S.T., Knights, D., Koenig, J.E., Ley, R.E., Lozupone, C.A., McDonald, D., Muegge B.D., Pirrung, M., Reeder, J., Sevinsky, J.R., Turnbaugh, P.J., Walters, W.A., Widmann, J., Yatsunenko, T., Zaneveld, J., Knight, R., 2010. QIIME allows analysis of high-throughput community sequencing data. Nature Methods 7: 335-336.

Caritat, P., Hall, G., Gislason, S.R., Belsey, W., Braun, M., Goloubeva, N.I., Olsen, H.K., Scheie, J.O., Vaive, J.E., 2005. Chemical composition of arctic snow: concentrations level and regional distribution of major elements. Sci. Total Environ. 336: 183-199.

Chameides, W.L. and Davis, D.D., 1982. The free-radical chemistry of cloud droplets and its impact upon the composition of rain. J. Geophys. Res., 87, 4863-4877.

Chenet, A.L., Fluteau, F., Courtillot, V., 2005. Modelling massive sulphate aerosol pollution, following the large 1783 Laki basaltic eruption. Earth Planet. Sci. Lett. 236: 721-731.

Cuoco, E., Tedesco, D., Poreda, R.J., Williams, J.C., De Francesco, S., Balagizi, C. and Darrah, T.H., 2013. Impact of volcanic plume emissions on rain water chemistry during the January 2010 Nyamuragira eruptive event: Implications for essential potable water resources. J. Hazard. Materials 244-245: 570-581.

D'Alessandro, W., Aiuppa, A., Bellomo, S., Brusca, L., Calabrese, S., Kyriakopoulos, K., Liotta, M., Longo, M., 2013. Sulphur-gas concentrations in volcanic and geothermal areas in Italy and Greece: Characterising potential human exposures and risks. J. Geochem. Exploration 131: 1-13.

Davidson, C.I., 1989. Mechanism of wet and dry deposition of atmospheric contaminants to snow surfaces. In: H. Oeschger and C.C. Langway, Jr. (Eds): The Environmental Records in Glaciers and Ice Sheets, S. Bernhard, Dahlem Konferenzen, 1989, pp. 29-51.

Davies, T.D. 1989. Episodic acidification of fresh waters in Europe (abstract). EOS Transactions, Am. Geophys. Union 70: 1122.

Delmelle, P., 2003. Environmental impacts of tropospheric volcanic gas plumes, in: C. Oppenheimer, D.M. Pyle, J. Barclay (Eds.), Volc. Degassing, Geol. Society, London, Special Publication 213: 381-399. 
Delmelle, P., Stix, J., Baxter, P.J., Garcia-Alvarez J., Barquero, J., 2002. Atmospheric dispersion, environmental effects and potential health hazard associated with the low-altitude gas plume of Masaya volcano, Nicaragua. Bull. Volcanol. 64: 423-434.

Delmelle, P., Lambert, M., Dufrene, Y., Gerin, P., Óskarsson, N., 2007. Gas/aerosol-ash interaction in volcanic plumes: new insights from surface analyses of fine ash particles. Earth Planet. Sci. Lett. 259: 159-170.

Delmelle, P., Maters, E., Oppenheimer, C., 2015. Chapter 50 - Volcanic Influences on the Carbon, Sulfur, and Halogen Biogeochemical Cycles. In: H. Sigurdsson (Editor). The Encyclopedia of Volcanoes (Second Edition). Academic Press, Amsterdam, pp. 881-893.

Dore, A.J., Choularton, T.W., Fowler, D., Crossley, A., 1992. Orographic enhancement of snowfall. Environ. Pollution 75: 175-179.

Dore, A.J., Sobik, M., Migała, K., 1999. Patterns of precipitation and pollutant deposition by rain and snow in the western Sudete Mountains. Polar Atmosph. Environ. 33: 3301-3312.

EC, 1998. Official Journal of the European Communities. Council directive 98/83/EC.

EC, 2004. European Commission, Framework regulation on 'Materials and articles intended to come into contact with food', No 1935/2004.

EC, 2006. European Commission, Regulation on 'Good manufacturing practice for materials and articles intended to come into contact with food', No 2023/2006.

EC, 2011. European Commission Regulation on 'Plastic materials and articles intended to come into contact with food' and its amendments, No 10/2011.

EEA, 2015. European Environmental Agency. Report on $\mathrm{SO}_{2}$ concentrations, http://www.eea.europa.eu/data-and-maps/indicators/eea-32-sulphur-dioxide-so2-emissions1/assessment-3

Eiriksdottir, G., Símonarson, B., Thorsteinsson, T., Gudmundsson, B., Jónmundsson, J.V., 1981. Seasonal variation of selenium in the blood of sheep: Experiment at Hvanneyri in 1980. J. Agr. Res. Icel. 13: 25-33 (English summary).

Eiriksdottir, E.S., 2008. Efnasamsetning úrkomu á Íslandi, Samantekt gagna frá Rjúpnahæð, Írafossi, Vegatungu, Litla-Skarði og Langjökli. Jarðvísindastofnun Háskólans, RH-01-2008.

Eiriksdottir, E.S., Gislason, S.R., Snorrason, Á., Harðardóttir, J., Porláksdóttir, S.B., Sveinbjörnsdóttir, Á.E., 2013. Efnasamsetning, rennsli og aurburður straumvatna á Austurlandi X. Gagnagrunnur Jarðvísindastofnunar of Veðurstofnunar. Report RH-13-2013.

Eiriksdottir, E.S., Sigurdsson, Á., Gislason, S.R., Torssander, P., 2014a. Chemical Composition of Precipitation and River Water in Southern Iceland: Effects of Eyjafjallajökull Volcanic Eruptions and Geothermal Power Plants. Procedia Earth Planet. Sci. 10: 358-364. 
Eiriksdottir E.S., Sigurdsson, Á., 2014b. Efnasamsetning úrkomu á Mjóanesi við Pingvallavatn 2008-2012. Jarðvisinastofnun Háskólans og Veðurstofa Íslands. Report RH-01-2014.

Eiriksdottir, E.S., Gislason, S.R., Oelkers, E.H., 2015. Direct evidence of the feedback between climate and nutrient, major, and trace element transport to the oceans. Geochim. Cosmochim. Acta 166: 249-266.

Eiriksdottir, E.S., Oelkers, E.H., Hardardottir J., Gislason, S.R., 2017. The impact of damming on riverine fluxes to the ocean: A case study from Eastern Iceland. Water Research 113: 253-276

Flaathen, T.K., Gislason, S.R., 2007. The effect of volcanic eruptions on the chemistry of surface waters: The 1991 and 2000 eruptions of Mt. Hekla, Iceland. J. Volcanol. Geotherm. Res. 164: 293-316.

Flaathen, T.K., Gislason, S.R., Oelkers, E.H., Sveinbjörnsdóttir, Á.E., 2009. Chemical evolution of the Mt. Hekla, Iceland, groundwaters: A natural analogue for $\mathrm{CO}_{2}$ sequestration in basaltic rocks. App. Geochem. 24: 463-474.

Floor, G.H., Calabrese, S., Román-Ross, G., D'Alessandro, W., Aiuppa, A., 2011. Selenium mobilization in soils due to volcanic derived acid rain: An example from Mt Etna volcano, Sicily. Chem. Geol. 289: 235-244.

Galeczka, I., Oelkers, E.H., Gislason, S.R., 2014a. The chemistry and element fluxes of the July 2011 Múlakvísl and Kaldakvísl glacial floods, Iceland. J. Volcanol. Geotherm. Res. 273: 4157.

Galeczka I., Wolff-Boenisch, D., Oelkers E. H., Gislason S. R., 2014b. An experimental study of basaltic glass $-\mathrm{H}_{2} \mathrm{O}-\mathrm{CO}_{2}$ interaction at 22 and $50^{\circ} \mathrm{C}$ : Implications for subsurface storage of $\mathrm{CO}_{2}$. Geochim. Cosmochim. Acta 126: 123-145.

Galeczka, I., Sigurdsson, G., Eiriksdottir, E.S., Oelkers, E.H., Gislason, S.R., 2016. The chemical composition of rivers and snow affected by the 2014/2015 Bárðarbunga eruption, Iceland. J. Volcanol. Geotherm. Res. 316: 101-119.

Gauthier, P.J., Sigmarsson, O., Gouhier, M., Haddadi, B., Moune, S., 2016. Elevated gas flux and trace metal degassing from the 2014-2015 fissure eruption at the Bárðarbunga volcanic system, Iceland. J. Geophys. Res. Solid Earth 121: 1610-1630.

Gislason, S.R., 1990. Chemistry of precipitation on the Vatnajökull glacier and the chemical fractionation caused by the partial melting of snow. Jökull 40: 97-117.

Gislason S.R., 1992. Efnagreiningar 1985-1992. Institute of Earth Sciences, RH-23-92. A report in Icelandic, $28 \mathrm{pp}$.

Gislason, S.R., 1993. Efnafræði úrkomu, jökla, árvatns, stöðuvatna og grunnvatns á Íslandi. Náttúrufræðingurinn 63: 219-236.

Gislason, S.R., Eugster, H.P., 1987a. Meteoric water-basalt interactions: I. A laboratory study. Geochim. Cosmochim. Acta 51: 2827-2840. 
Gislason S.R., Eugster H.P., 1987b. Meteoric water-basalt interactions: II. A field study in NE Iceland. Geochim. Cosmochim. Acta 51, pp. 2841-2855.

Gislason, S.R., Arnorsson, S., Armannsson, H., 1996. Chemical weathering of basalt in Southwest Iceland; effects of runoff, age of rocks and vegetative/glacial cover. Am. J. Sci. 296: 837-907.

Gislason, S.R., Stefánsdóttir, M.B., Eiriksdottir, E.S., 2000. ARCTIS, Regional Investigation of Arctic Snow Chemistry: Results from the Icelandic Expeditions, 1997-1999. Raunvísindastofnun, RH-05-2000.

Gislason, S.R., Snorrason, Á., Kristmannsdóttir, H.K., Sveinbjörnsdóttir, Á.E., Torsander, P., Ólafsson, J., Castet, S., Dupré, B., 2002. Effects of volcanic eruptions on the $\mathrm{CO}_{2}$ content of the atmosphere and the oceans: the 1996 eruption and flood within the Vatnajökull Glacier, Iceland. Chem. Geol. 190: 181-205.

Gislason, S.R., Torssander, P., 2006. Response of Sulfate Concentration and Isotope Composition in Icelandic Rivers to the Decline in Global Atmospheric $\mathrm{SO}_{2}$ Emissions into the North Atlantic Region. Environ. Sci. Technol. 40: 680-686.

Gislason, S. R., Hassenkam, T., Nedel, S., Bovet, N., Eiriksdottir, E. S., Alfredsson, H. A., Hem, C. P., Balogh, Z. I., Dideriksen, K., Óskarsson, N., Sigfusson, B., Larsen, G., Stipp, S. L. S., 2011. Characterization of Eyjafjallajökull volcanic ash particles and a protocol for rapid risk assessment. PNAS, 108: 7307-7312.

Gislason, S.R., Stefánsdóttir, G., Pfeffer, M.A., Barsotti, S., Jóhannsson, T., Galeczka, I., Bali, E., Sigmarsson, O., Stefánsson, A., Keller, N.S., Sigurdsson, Á., Bergsson, B., Galle, B., Jacobo, V.C., Arellano, S., Aiuppa, A., Jónasdóttir, E.B., Aeiríksdóttir, E.S., Jakobsson, S., Guðfinnsson, G.H., Halldórsson, S.A., Gunnarsson, H., Haddadi, B., Hjónsdóttir, I., Thordarson, T., Riishuus, M., Högnadóttir, T., Dürig, T., Pedersen, G.B.M., Höskuldsson, Á., Gudmundsson, M.T., 2015. Environmental pressure from the 2014-15 eruption of Bárðarbunga volcano, Iceland. Geochem. Perspect. Lett. 1: 84-93.

Glasow, R., Bobrowski, N., Kern, C., 2009. The effect of volcanic eruptions on atmospheric chemistry. Chem. Geol. 263: 131-142.

Glasow, R., 2010. Atmospheric chemistry in volcanic plumes. PNAS 107, 15: 6594-6599.

Graedel, T.E., Franey, J.P., 1975. Field measurements of submicron aerosol washout by snow. Geophys. Res. Lett. 2: 325-328.

Grellier, L., Marécal, V., Josse, B., Hamer, P.D., Roberts, T.J., Aiuppa, A., Pirre, M., 2014. Towards a representation of halogen chemistry withn volcanic plumes in a chemistry transport model. Geosci. Model Developmnet, Discussion 7: 2581-2650.

Gudmundsson, M.T., Sigmundsson, F., Bjornsson, H., 1997. Ice-volcano interaction of the 1996 Gjalp subglacial eruption, Vatnajokull, Iceland. Nature 389: 954-957. 
Gudmundsson, M.T., Högnadóttir, T., 2007. Volcanic systems and calderas in the Vatnajökull region, central Iceland: Constraints on crustal structure from gravity data. J. Geodynam. 43: $153-169$.

Gudmundsson, M.T., Larsen, G., Höskuldsson, Á., Gylfason, Á.G., 2008. Volcanic hazards in Iceland. Jökull 58: 251-268.

Gudmundsdottir, E., Oladottir, B.A., Moreland, W., Gudnason, J., 2016. Tephra in the Effusive Bardarbunga 2014-2015 Eruption, Iceland. Conference Abstract, Nordic Geological Winter Meeting Helsinki, 13-15 January, 2016.

Gudmundsson, M.T., Jónsdóttir, K., Hooper, A., Holohan, E.P., Halldórsson, S.A., Ófeigsson, B.G., Cesca, S., Vogfjörd, K.S., Sigmundsson, F., Högnadóttir, Th., Einarsson, P., Sigmarsson, O., Jarosch, A.H., Jónasson, K., Magnússon, E., Hreinsdóttir, S., Bagnardi, M., Parks, M.M., Hjörleifsdóttir, V., Pálsson, F., T.R. Walter, M.P.J. Schöpfer, S. Heimann, H.I. Reynolds, Dumont, S., Bali, E., Gudfinnsson, G.H., Dahm, T., Roberts, M.J., Hensch, M., Belart, J. M.C., Spaans, K., Jakobsson, S., Gudmundsson, G.B., Fridriksdóttir, H.M., Drouin, V., Dürig, T., Adalgeirsdóttir, G., Riishuus, M.S., Pedersen, G.B.M., van Boeckel, T., Oddsson, B., Pfeffer, M.A., Barsotti S., Bergsson, B., Donovan, A., Burton, M.R., Aiuppa, A., 2016. Gradual caldera collapse at Bárðarbunga volcano, Iceland regulated by lateral magma outflow. Science 353.

Gunnarsson-Robin, J., Stefánsson, A., Ono, S., Torssander, P. 2017. Sulfur isotopes in Icelandic thermal fluids. J. Volcanol. Geotherm. Res. In Press, Corrected Proof, Available online 11 February 2017.

Gysi, A.P., Stefánsson, A., 2011. $\mathrm{CO}_{2}-$ water-basalt interaction. Numerical simulation of low temperature $\mathrm{CO}_{2}$ sequestration into basalts. Geochim. Cosmochim. Acta 75: 4728-4751.

Halmer, M.M., Schmincke, H.U., Graf, H.F., 2002. The annual volcanic gas input into the atmosphere, in particular into the stratosphere: a global data set for the past 100 years. J. Volcanol. Geotherm. Res. 115: 511-528.

Hannesdóttir, L.B., 2011. Minnisblað: Flóð í Hágöngulón 13. júlí 2011. Report for Landsvirkjun Power Company.

Hannesdóttir, H., Björnsson, H., Pálsson, F., Aðalgeirsdóttir, G., Guðmundsson, S., 2014. Area, volume and mass changes of southeast Vatnajökull ice cap, Iceland, from the Little Ice Age maximum in the late 19th century to 2010. The Cryosphere Discuss. 8: 4681-4735.

Hartley, M.E., Thordarson, T., 2013. The 1874-1876 volcano-tectonic episode at Askja, North Iceland: Lateral flow revisited. Geochem. Geophys. Geosystems 14: 2286-2309.

Herut, B., Spiro, B., Starinsky, A., Katz, A., 1995. Sources of sulfur in rainwater as indicated by isotopic $\delta^{34} S$ data and chemical composition, Israel. Atmosph. Environ. 29: 851-857. 
Hong, S., Candelone, J.P., Patterson, C.C., Boutron, C.F., 1994. Greenland ice evidence of hemispheric scale pollution for lead two millennia ago by Greek and Roman civilizations. Science 265:1841-3.

Hong, S., Candelone, J.P., Patterson, C.C., Boutron, C.F., 1996. History of ancient copper smelting pollution during Roman and medieval times recorded in Greenland ice. Science 272: 246-9.

Hreinsdóttir, S., Sigmundsson, F., Roberts, M.J., Björnsson, H., Grapenthin, R., Arason, P., Árnadóttir, T., Hólmjárn, J., Geirsson, H., Bennett, R.A., Gudmundsson, M.T., Oddsson, B., Ófeigsson, B.G., Villemin, T., Jónsson, T., Sturkell, E., Höskuldsson, A., Larsen, G., Thórdarson, T., Óladottir, B.A., 2014. Volcanic plume height correlated with magma-pressure change at Grímsvötn Volcano, Iceland. Nature Geosci. 7: 214-218.

IMO, 2017. Icelandic Meteorological Office www.vedur.is.

Icelandic Health Regulation, 2002. Reglugerð um brennisteinsdíoxíð, köfnunarefnisdíoxíð og köfnunarefnisoxíð, bensen, kolsýring, svifryk og blý í andrúmsloftinu og upplýsingar til almennings, 251/2002.

IPCC, 1994. Intergovernmental Panel of Climate Change, Climate Change 1994, Cambridge University Press, 1995. Radiative effects of aerosols.

Jacobson, M.Z., 1997a. Development and application of a new air-pollution modeling system II. Aerosol module structure and design. Atmos. Environ. 31:131-144.

Jacobson M.Z., 1997b. Development and application of a new air-pollution modeling system III. Aerosol-phase simulations. Atmos. Environ., 31: 587-608.

Jacobson, M.Z., 1998. Fundamentals of Atmospheric Modeling. Cambridge University Press, Cambridge, 1998. Aerosol scattering and absorption.

Johannessen, M., Henriksen, A. 1978. Chemistry of snow meltwater: changes in concentration during melting. Water Resources Res. 14: 615-619.

Jóhannesson, T., Eiríksson, T., Gudmundsdóttir, K.B., Sigurdarson, S., Kristinsson, J., 2007. Overview: Seven trace elements in Icelandic forage. Their value in animal health and with special relation to scarpie. Icelandic Agricultural Sci. 20: 3-24.

Jones, M., Hembury, D., Palmer, M., Tonge, B., Darling, W.G., Loughlin, S., 2011. The weathering and element fluxes from active volcanoes to the oceans: a Montserrat case study. Bull. Volcanol. 73: 207-222.

Junge, C.E., Werby. R.T. 1958. The concentration of chloride, sodium, potassium, calcium and sulphate in rain water over the United States. J. Meteorol. 15: 417-425.

Jylha, K., 2000. Removal by snowfall of emissions from a coal-fired power station: observations and modelling. Water, Air, Soil Pollution 120: 397-420. 
Kaasalainen, H., Stefánsson, A., 2012. The chemistry of trace metals in the surface geothermal waters and steam, Iceland. Chem. Geol. 330-331: 60-85.

Keeling, R., Tans, P., 2016. Trends in Atmospheric Carbon Dioxide. NOAA, Earth System Research Laboratory; http://www.esrl.noaa.gov/gmd/ccgg/trends/data.html

Kepski, D., Blas, M., Sobik, M., Polkowska, Z., Grudzinska, K., 2016. Progressing pollutant elution from snowpack and evolution of its physicochemical properties during melting period - a case study from the Sudetes, Poland. Water Air Soil Pollution 227: 112-132.

Kristmannsdóttir, H., Björnsson, A., Pálsson, S., Sveinbjörnsdóttir, Á.E., 1999. The impact of the 1996 subglacial volcanic eruption in Vatnajökull on the river Jökulsá á Fjöllum, North Iceland. J. Volcanol. Geotherm. Res. 92: 359-372.

Kyro, E.M., Gronholm, T., Vuollekoski, H., Virkkula, A, Kumala, M., Laakso, L., 2009. Snow scavenging of ultrafine particles: field measurements and parametrization. Boreal Environ. Res. 14: 527-538.

Larose, C., Berger, S., Ferrari, C., Navarro, E., Dommergue, A., Schneider, D., Vogel, T.M., 2010. Microbial sequences retrieved from environmental samples from seasonal Arctic snow and meltwater from Svalbard, Norway. Extremophiles 14: 205-212.

Lelieveld, J., 1993. Multi-phase processes in the atmospheric sulphur cycle. In: Wollast, R., Mackenzie, F.T., Chou, L. (Eds.). Interactions of C, N, P and S Biogeochemical Cycles and Global Change, Springer-Verlag, Berlin-Heidelberg, 305-331.

Liang, J., Jacobson, M.Z., 1999. A study of sulphur dioxide pathways over a range of liquid water contents, pH values and temperatures. J. Geophys. Res. 104: 13,749-13,769.

Lutz, S., Anesio, A.M., Villar, S.E. J., Benning, L.G., 2014. Variations of algal communities cause darkening of a Greenland glacier. FEMS Microbiol. Ecol. 89, 2: 402-414.

Lutz, S., Anesio, A.M., Edwards, A., Benning, L.G., 2015. Microbial diversity on Icelandic glaciers and ice caps. Frontiers Microbiol. 6.

Lutz, S., Anesio, A.M., Raiswell, R., Edwards, A., Newton, N.J., Gill F. and Benning L.g., (2016) The Biogeography of Red Snow Microbiomes and their Role in Melting Arctic Glaciers Nature Communications 7: articel no 11968

Lutz, S., Anesio, A.M., Edwards, A., Benning, L.G., 2017. Linking microbial diversity and functionality of arctic glacial surface habitats. Environ. Microbiol. 19, 2: 551-565.

Marini, L., Moretti, R., Accornero, M., 2011. Sulfur isotopes in magmatic-hydrothermal systems, melts, and magmas. Rev. Min. Geochem. 73: 423-492

Magono, C., Endoh, T., Ueno, F., Kubota, S., Itsaka, M., 1979. Direct observations of aerosols attached to falling snow crystals. Tellus 31: 102-114. 
Margitan, J.J., 1984. Mechanism of the atmospheric oxidation of sulfur dioxide. Catalysis by hydroxyl radicals. J. Phys. Chem. 88: 3314-3318.

Mather, T.A., Pyle, D.M., Oppenheimer, C., 2003. Tropospheric volcanic aerosol. In: Robock, A., Oppenheimer, C. (Eds.), Volcanism and the Earth's Atmosphere. Geophys. Monogr. Ser. 137: 189-212.

Morris, C.E., Sands, D.C, Vinatzer, B.A, Glaux, C., Guilbaud, C., Buffière, A., Yan, S., Dominguez, H., Thompson, B.M., 2008. The life history of the plant pathogen Pseudomonas syringae is linked to the water cycle. The ISME Journal 2: 321-334.

Morris, C.E., Sands, D.C., Vanneste, J.L., Montarry, J., Oakley, B., Guilbaud, C., Glaux, C., 2010. Inferring the evolutionary history of the plant pathogen Pseudomonas syringae from its biogeography in headwaters of rivers in North America, Europe, and New Zealand. mBio 1:e00107-10.

Moune, S., Gauthier, P.-J., Gislason, S.R., Sigmarsson, O., 2006. Trace element degassing and enrichment in the eruptive plume of the 2000 eruption of Hekla volcano, Iceland. Geochim. Cosmochim. Acta 70: 461-479.

Menard, G., Moune, S., Vlastélic, I., Aguilera, F., Valade, S., Bontemps, M., González, R., 2014. Gas and aerosol emissions from Lascar volcano (Northern Chile): Insights into the origin of gases and their links with the volcanic activity. J. Volcanol. Geotherm. Res. 287: 51-67.

Nawrot, A.P., Migala, K., Luks, B., Pakszysz, P., Glowacki, P., 2016. Chemistry of snow cover and acidic snowfall during a season with a high level of air pollution on the Hans Glacier, Spitsbergen. Polar Sci. In press.

Olsson, J., Stipp, S.L.S., Dalby, K.N., Gislason, S.R., 2013. Rapid release of metal salts and nutrients from the 2011 Grímsvötn, Iceland volcanic ash. Geochim. Cosmochim. Acta 123: 134-149.

Ono, S., Wing, B., Rumble, D., Farquhar, J., 2006. High precision analysis of all four stable isotopes of sulfur $\left({ }^{32} \mathrm{~S},{ }^{33} \mathrm{~S},{ }^{34} \mathrm{~S}\right.$ and $\left.{ }^{36} \mathrm{~S}\right)$ at nanomole levels using a laser fluorination isotope-ratio-monitoring gas chromatography-mass spectrometry. Chem. Geol. 225: 30-39.

Oppenheimer, C., 2003. Volcanic degassing. Treatise on Geochemistry 3: 123-166.

Óskarsson, N., 1981. The chemistry of Icelandic lava incrustations at the latest stage of degassing. J. Volcanol. Geotherm. Res. 22: 97-121.

Pandis, S.N., Seinfeld, J.H., 1989. Sensitivity analysis of a chemical mechanism for aqueousphase atmospheric chemistry. J. Geophys. Res. 94, 1105-1126.

Paramonov, M., Gronholm, T., Virkkula, A., 2011. Below-cloud scavenging of aerosols particles by snow at an urban site in Finland. Boreal Environ. Res. 16: 304-320. 
Pálsson, F., Gunnarsson, A., Jónsson, P., Steinpórsson, S., Pálsson, H.S., 2015. Vatnajökull: mass balance, meltwater drainage and surface velocity of the glacial year 2014_15. Institute of Earth Sciences, University of Iceland and National Power Company. RH-06-2015.

Pinto, J.P., Turco, R.P., Toon, O.B., 1989. Self-limiting physical and chemical effects in volcanic eruption clouds. J. Geophys. Res.: Atmos. 94(D8): 11165-11174.

Pruppacher, H.R., Klett, J.D., 1997. Microphysics of clouds and precipitation. Second revised and enlarged edition with and introduction to cloud chemistry and cloud electricity. Kluwer Academic Publisher, Dordrecht.

Redington, A.L., Derwent, R.G., Witham, C.S., Manning, A.J., 2009. Sensitivity of modelled sulphate and nitrate aerosol to cloud, $\mathrm{pH}$ and ammonia emissions. Atmos. Environ. 43: 32273234.

Rees, C.E., Jenkins, W.J., Monster, J., 1978. The sulfur isotopic composition of ocean water sulfate. Geochim. Cosmochim. Acta 42: 377-382

Roberts, M.J., Russell, A.J., Tweed, F.S., Knudsen, Ó., 2000. Ice fracturing during jökulhlaups: implications for englacial flood water routing and outlet development. Earth Surface Processes and Landforms 25: 1429-1446.

Russell, A.J., Roberts, M.J., Fay, H., Marren, P.M., Cassidy, N.J., Tweed, F.S., Harris, T., 2006. Icelandic jökulhlaup impacts: Implications for ice-sheet hydrology, sediment transfer and geomorphology. Geomorphol. 75: 33-64.

Russell, A.J., Tweed, F.S., Roberts, M.J., Harris, T.D., Gudmundsson, M.T., Knudsen, Ó., Marren, P.M., 2010. An unusual jökulhlaup resulting from subglacial volcanism, Sólheimajökull, Iceland. Quaternary Sci. Rev. 29: 1363-1381.

Schmidt, A., Carslaw, K.S., Mann, G.W., Wilson, M., Breider, T.J., Pickering, S.J., Thordarson, Th., 2010. The impact of the 1783-1784 AD Laki eruption on global aerosol formation processes and cloud condensation nuclei. Atmos. Chem. Phys. 10: 6025-6041.

Schmidt, A., Leadbetter, S., Theys, N., Carboni, E., Witham, C.S., Stevenson, J.A., Birch, C.E., Thordarson, T., Turnock, S., Barsotti, S., Delaney, L., Feng, W., Grainger, R.G., Hort, M.C., Höskuldsson, Á., Ialongo, I., Ilyinskaya, E., Jóhannsson, T., Kenny, P., Mather, T.A., Richards, N.A.D., Shepherd, J., 2015. Satellite detection, long-range transport, and air quality impacts of volcanic sulfur dioxide from the 2014-2015 flood lava eruption at Bárðarbunga (Iceland). J. Geophys. Res.: Atmos. 120: 9739-9757.

Schmidt, A., Skeffington, R.A., Thordarson, T., Self, S., Forster, P.M., Rap, A., Ridgwell, A., Fowler, D., Wilson, M., Mann, G.W., Wignall, P.B., Carslaw, K.S., 2016. Selective environmental stress from sulphur emitted by continental flood basalt eruptions. Nature Geosci. 9: 77-82. 
Schwanck, F., Simões, J.C., Handley, M., Mayewski, P.A., Bernardo, R.T., Aquino, F.E., 2016. Anomalously high arsenic concentration in a West Antarctic ice core and its relationship to copper mining in Chile. Atmos. Environ. 125: 257-264.

Seinfeld, J.H., Pandis, S.N., 1998. Atmospheric Chemistry and Physics - From Air Pollution to Climate Change. John Wiley and Sons, Inc.

Seinfeld, J.H., Pandis, S.N., 2006. Aerosol microphysics: nucleation, condensation, coagulation, deposition. Atmos. Chem. Phys. Air Pollution, Wiley.

Shaw, G.E. 1989. Aerosol transport from sources to ice sheets. In: H. Oeschger and C.C. Langway, Jr. (Eds). The Environmental Records in Glaciers and Ice Sheets, S. Bernhard, Dahlem Konferenzen, 1989, pp. 13-27.

Shaw, G.E. 1995. The Arctic haze phenomenon. Bull. Am. Meteorol. Soci. 76: 2403-2413.

Sigmundsson, F., Hooper, A., Hreinsdottir, S., Vogfjord, K.S., Ofeigsson, B.G., Heimisson, E.R., Dumont, S., Parks, M., Spaans, K., Gudmundsson, G.B., Drouin, V., Arnadottir, T., Jonsdottir, K., Gudmundsson, M.T., Hognadottir, T., Fridriksdottir, H.M., Hensch, M., Einarsson, P., Magnusson, E., Samsonov, S., Brandsdottir, B., White, R.S., Agustsdottir, T., Greenfield, T., Green, R.G., Hjartardottir, A.R., Pedersen, R., Bennett, R.A., Geirsson, H., La Femina, P.C., Bjornsson, H., Palsson, F., Sturkell, E., Bean, C.J., Mollhoff, M., Braiden, A.K., Eibl, E.P.S., 2015. Segmented lateral dyke growth in a rifting event at Bárðarbunga volcanic system, Iceland. Nature 517: 191-195.

Sigrudsson, F., Einarsson, K., 1988. Groundwater resources of Iceland - availability and demand. Jökull 38: 35-53.

Sigurdsson, A., Thorlacius, J.M. 2014. Niðurstöður efnagreininga á daglegum loft og úrkomusýnum frá Írafossi 2008-2011. Icelandic Meteorological Office Technical report ÁSig/JMTh/2014-01, 18 p.

Sigvaldason, G.E., Elisson, G., 1968. Collection and analysis of volcanic gases at Surtsey, Iceland. Geochim. Cosmochim. Acta 32: 797-805.

Símonarson, B., Eiríksdóttir, G., Sigurdarson, S., Thorsteinsson, T., 1984. Selenskortur og seleneitrun. Freyr 80: 910-912 (in Icelandic).

Snorrason, Á., Jónsson, P., Sigurdsson, O., Pálsson, S., Árnason, S., Víkingsson, S., Kaldal, I., 2002. November 1996 jökulhlaup on Skeidarársandur outwash plan. Iceland. In: Martin P., Baker V.R. and Garzón G. eds. Flood and Megaflood Processes and Deposits. Recent and Ancient Examples. Special Publ. 32 of the International Association of Sedimentologists, Blackwell Science, Oxford, 55-67.

Stefánsdóttir, M.B., Gislason, S.R., 2005. The erosion and suspended matter/seawater interaction during and after the 1996 outburst flood from the Vatnajökull Glacier, Iceland. Earth Planet. Sci. Lett. 237: 433-452. 
Stefánsson, A., Keller, N.S., Gunnarsson-Robin, J., Ono, S., 2015. Multiple sulfur isotope systematics of Icelandic geothermal fluids and the source and reactions of sulfur in volcanic geothermal systems at divergent plate boundaries. Geochim. Cosmochim. Acta 165: 307-323.

Stefánsson, A., Stefánsdóttir, G., Keller, N.S., Barsotti, S., Sigurdsson, Á., Porláksdóttir, S.B., Pfeffer, M.A., Eiriksdottir, E.S., Jónasdóttir, E.B., Löwis, S., Gislason, S.R., 2017a. Major impact of volcanic gases on the chemical composition of precipitation in Iceland during the 2014-15 Bárðarbunga eruption. J. Geophys. Res. Atmos. 122: 1971-1982.

Stefánsson, A., Hilton, D.R., Sveinbjörnsdóttir, Á.E., Torssander, P., Heinemeier, J., Barnes, J.D., Ono, S., Halldórsson, S.A., Fiebig, J., Arnórsson, S., 2017b. Isotope systematics of Icelandic thermal fluids. J. Volcanol. Geotherm. Res. In press, Corrected Proof.

Thode, H.G., Monster, J., Dunford, H.B., 1961. Sulphur isotope geochemistry. Geochim. Cosmochim. Acta 25: 150-174.

Tans, P., Keeling, R., 2016. Trends in Atmospheric Carbon Dioxide; NOAA/ESRL (www.esrl.noaa.gov/gmd/ccgg/trends/), Scripps Institution of Oceanography (scrippsco2.ucsd.edu/).

Thordarson, T., Self, S., Oskarsson, N., Hulsebosch, T., 1996. Sulfur, chlorine, and fluorine degassing and atmospheric loading by the 1783-1784 AD Laki (Skaftar Fires) eruption in Iceland. Bull. Volcanol. 58: 205-225.

Thordarson, T., Self, S., 2003. Atmospheric and environmental effects of the 1783-1784 Laki eruption: A review and reassessment. J. Geophys. Res.: Atmos. 108(D1): AAC 7-1-AAC 7-29.

Thordarson, T., Larsen, G., 2007. Volcanism in Iceland in historical time: Volcano types, eruption styles and eruptive history. J. Geodynam. 43: 118-152.

Thorlacius, J.M, 1997. Heavy metals and persistent organic pollutants in air and precipitation. Veðurstofa Islands Report. VI-G97034-TA02, Reykjavik, November 1997.

Timmreck, C., Graf, H.-F., Lorenz, S.J., Niemeier, U., Zanchettin, D., Matei, D., Jungclaus, J.H., Crowley, T.J., 2010. Aerosol size confines climate response to volcanic super-eruptions. Geophys. Res. Lett. 37(24): n/a-n/a.

Torssander, P. 1986. Origin of Volcanic Sulfur in Iceland - A Sulfur Isotope Study. Ph.D. thesis Stockholm University (1986), p. 164

Tómasson H., 1996. The jökuhlaup from Katla in 1918. Annals Glaciol. 22: 249-254.

Tranter, M. 1989. Episodic acidification of fresh waters in Canada (abstract). EOS Transactions, Am. Geophys. Union 70: 1122.

Wang, C., Chang, J.S., 1993. A 3-dimensional numerical model of cloud dynamics, microphysics, and chemistry, 4. Cloud chemistry and precipitation chemistry. J. Geophys Res. 98: $16,799-16,808$. 
Wen, H., Carignan, J., 2007. Reviews on atmospheric selenium: emissions, speciation and fate. Atmos. Environ. 41: 7151-7165.

White, D., 1999. The Physiology \& Biogeochemistry of Prokaryotes. second ed. Oxford University Press, Oxford.

WHO, 2006. World Health Organization. Guidelines for drinking-water quality [electronic resource]: incorporating first addendum. Vol. 1, Recommendations. - 3rd ed. 2006

Wigington, Jr., P.J., 1989. Episodic acidification of fresh waters in United States (abstract). EOS Transactions, Am. Geophys. Union 70: 1122.

Wolff-Boenisch, D., Gislason, S.R., Oelkers, E.H., 2004. The effect of fluoride on the dissolution rates of natural glasses at $\mathrm{pH} 4$ and $25^{\circ} \mathrm{C}$. Geochim. Cosmochim. Acta 68: 4571-4582.

21 CFR, 2016. Requirements of the Food and Drug Administration Regulations, USA. Electronic code of federal regulations (CFR), Title 21, Paragraph \$177.1520. US Food and Drug Administration.

\section{Figure captions}

Figure 1. Sampling locations on the Vatnajökull glacier and in the highlands NE of the glacier. The grey area labelled Holuhraun lava, represents the extent of this lava after the 2014-15 Bárðarbunga eruption. The weather stations operated by IMO on Brúarjökull, Hágöngur, and Kárahnjukar are shown as diamonds. The cross represents the Maríutungur area. Pránd is the snow sample located at the Prándarjökull glacier. The two dots superimposed on the map of Iceland depict the IMO rain monitoring station at the Mjóanes, and the snow coring location on the Langjökull glacier, respectively. The G01, G04 and BOR sampling locations are within the Gjálp-Grimsvötn area (see text).

Figure 2. Spatial distribution of the measured $\mathrm{pH}$ (a) of the bulk snow cores on the Vatnajökull glacier and in the highlands NE of the glacier. The (b), (c), and (d) illustrate the seawater corrected flux of $\mathrm{S}, \mathrm{Cl}$, and $\mathrm{F}$, respectively; in $\mathrm{mg} / \mathrm{m}^{2} / \mathrm{month}$, see text.

Figure 3. The $\mathrm{pH}$ and dissolved $\mathrm{SO}_{4}$ concentration (as measured with IC) of D05 snowmelt water as a function of increment depth. The vertical line on the $\mathrm{pH}$ plot represents the $\mathrm{pH}$ of the pure water equilibrated with $395 \mathrm{ppmv}$ of $\mathrm{CO}_{2}$ at $25^{\circ} \mathrm{C}$ as calculated with the PHREEQC computer code. The sampling site is located at an elevation of 1206 m.a.s.l.

Figure 4. The $\mathrm{pH}$ and dissolved $\mathrm{SO}_{4}$ concentration (as measured with IC) of M03 snowmelt water as a function of depth. The vertical line on the $\mathrm{pH}$ plot represents the $\mathrm{pH}$ of the pure water equilibrated with 395 ppmv of $\mathrm{CO}_{2}$ at $25{ }^{\circ} \mathrm{C}$ as calculated with the PHREEQC computer code. The sampling site is located at an elevation of 1331 m.a.s.l. 
Figure 5. The concentrations of major and trace dissolved elements with depth in snow core D05. Snow that fell during the most effusive period of the volcanic eruption in early winter is located in the deepest part of the snow core.

Figure 6. The concentration of major and trace dissolved elements with depth in snow core M03. Snow that fell during the most effusive period of the volcanic eruption in early winter is located in the deepest part of the snow core.

Figure 7. The ratios of elements to $\mathrm{Cl}$ in the snowmelt collected from the Vatnajökull glacier and the highlands NE of the glacier, and from the reference Langjökull winter snow collected in 1997-2006. The seawater ratio was taken from Bruland (1983).

Figure 8. The concentrations of selected elements as a function of the in situ $\mathrm{pH}\left(\right.$ at $\left.0.1{ }^{\circ} \mathrm{C}\right)$ of the snow samples. The in situ $\mathrm{pH}$ was calculated using PHREEQC computer code.

Figure 9. The concentrations of selected components in snow versus in situ $\mathrm{pH}$. Concentrations were corrected for the seawater component as described in the text. The in situ $\mathrm{pH}$ was calculated using PHREEQC computer code.

Figure 10. The theoretical $\mathrm{pH}$ calculated based on the seawater uncorrected (a) and seawater corrected (b) $\mathrm{Cl}, \mathrm{SO}_{4}$, and $\mathrm{F}$ concentrations versus in situ $\mathrm{pH}$ of snow samples.

Figure 11. The aqueous species dominating the charge balance of the D05 bulk core (a, b), M03 bulk core $(c, d)$, and in the most acidic increment D05_17 shown as percent of charge contributed by each species. Cations are illustrated on the left (a, c, e), anions on the right (b, d, f). Speciation distribution was calculated at $25{ }^{\circ} \mathrm{C}$ using measured dissolved constituents and the PHREEQC computer code.

Figure 12. The results of the mixing model between rain water and volcanic gas and rain water and basalt (a) and the reaction path simulation (b). The lines represent the theoretical composition of the final fluid when basalt (simulation 1) and volcanic gas (simulation 2), respectively are assumed to be dissolved in unpolluted seawater originating rain water. The dots represent measured concentrations in the snow.

Figure 13. Enrichment factor in snow collected during this study with respect to Holuhraun gas plume (Gauthier et al., 2016) for several trace elements and volatiles relative to $\mathrm{Mg}$. The symbols represent the average enrichment factor for bulk snow cores, the D05 and M03 increments, and the Holuhraun snow (Galeczka et al., 2016). The error bars represent the standard deviation.

\section{Table captions}

Table 1. Comparison of the average, minimum, and maximum $\mathrm{pH}$, conductivity (Cond.), and dissolved element concentrations between snow samples collected from the Langjökull glacier in 1997-2006 and from the Vatnajökull glacier in 2015. The Vatnajökull snow samples are presented both as bulk samples and as D05 snow core increments. 
Table 2. The logistics and physical parameters of the bulk snow samples collected from the Vatnajökull glacier in 2015. The temperatures given in the table are reference temperatures at which $\mathrm{pH}$ and conductivity were measured. The in situ $\mathrm{pH}$ and charge imbalance were calculated using the PHREEQC computer code at in situ melting temperature of $0.1{ }^{\circ} \mathrm{C}$ (Parkhurst and Appelo, 1999).

Table 3. Concentrations of dissolved constituents and $\mathrm{S}$ isotopes in melted bulk snow samples from Vatnajökull glacier and the highland NE of the glacier. Values in italics were measured by ALS Sweden (see text). The uncertainty for $\delta^{34} \mathrm{~S}$ analyses is $\pm 0.2 \%$.

Table 4. Measured $\mathrm{pH}$ and conductivity at the temperature given in the table $\left(\mathrm{T}\left[{ }^{\circ} \mathrm{C}\right] / \mathrm{pH} ; \mathrm{T}\right.$ $\left[{ }^{\circ} \mathrm{C}\right] /$ Conductivity), and chemical composition of the increments from the D05 core. The charge imbalance and in situ $\mathrm{pH}$ was calculated using the PHREEQC computer code at in situ melting temperature of $0.1{ }^{\circ} \mathrm{C}$ (Parkhurst and Appelo, 1999). Increment numbers increase with depth; D05_1 was located at the surface whereas D05_21 was at the bottom of the winter snow layer. Weight of sediments in all increments were $<0.01 \mathrm{~g}$.

Table 5. Concentration of dissolved constituents in melted snow samples collected from the D05 core increments. Values in italics were measured by ALS Sweden (see text).

Table 6. Measured $\mathrm{pH}$, conductivity at the temperature given in the table $\left(\mathrm{T}\left[{ }^{\circ} \mathrm{C}\right] / \mathrm{pH} ; \mathrm{T}\right.$ $\left[{ }^{\circ} \mathrm{C}\right] /$ Conductivity) and chemical composition of the M03 core increments. The charge imbalance and in situ $\mathrm{pH}$ was calculated using the PHREEQC computer code at in situ melting temperature of $0.1{ }^{\circ} \mathrm{C}$ (Parkhurst and Appelo, 1999). Increments numbers increase with depth; M03 1 was collected at the surface, whereas M03 44 was at the bottom of winter snow layer.

Table 7. Summer layers collected below the respective bulk snow samples, their names, measured $\mathrm{pH}$, conductivity at the temperature given in the table $\left(\mathrm{T}\left[{ }^{\circ} \mathrm{C}\right] / \mathrm{pH} ; \mathrm{T}\left[{ }^{\circ} \mathrm{C}\right] / \mathrm{Conductivity}\right)$ and chemical composition. The charge imbalance and in situ $\mathrm{pH}$ was calculated using the PHREEQC computer code at in situ melting temperature of $0.1^{\circ} \mathrm{C}$ (Parkhurst and Appelo, 1999).

Table. 8. Bacterial community composition in sample T03 based on 16S rRNA gene sequences and OTU clustering at $97 \%$ similarity. Table shows taxa with $>0.1 \%$ relative abundance. 


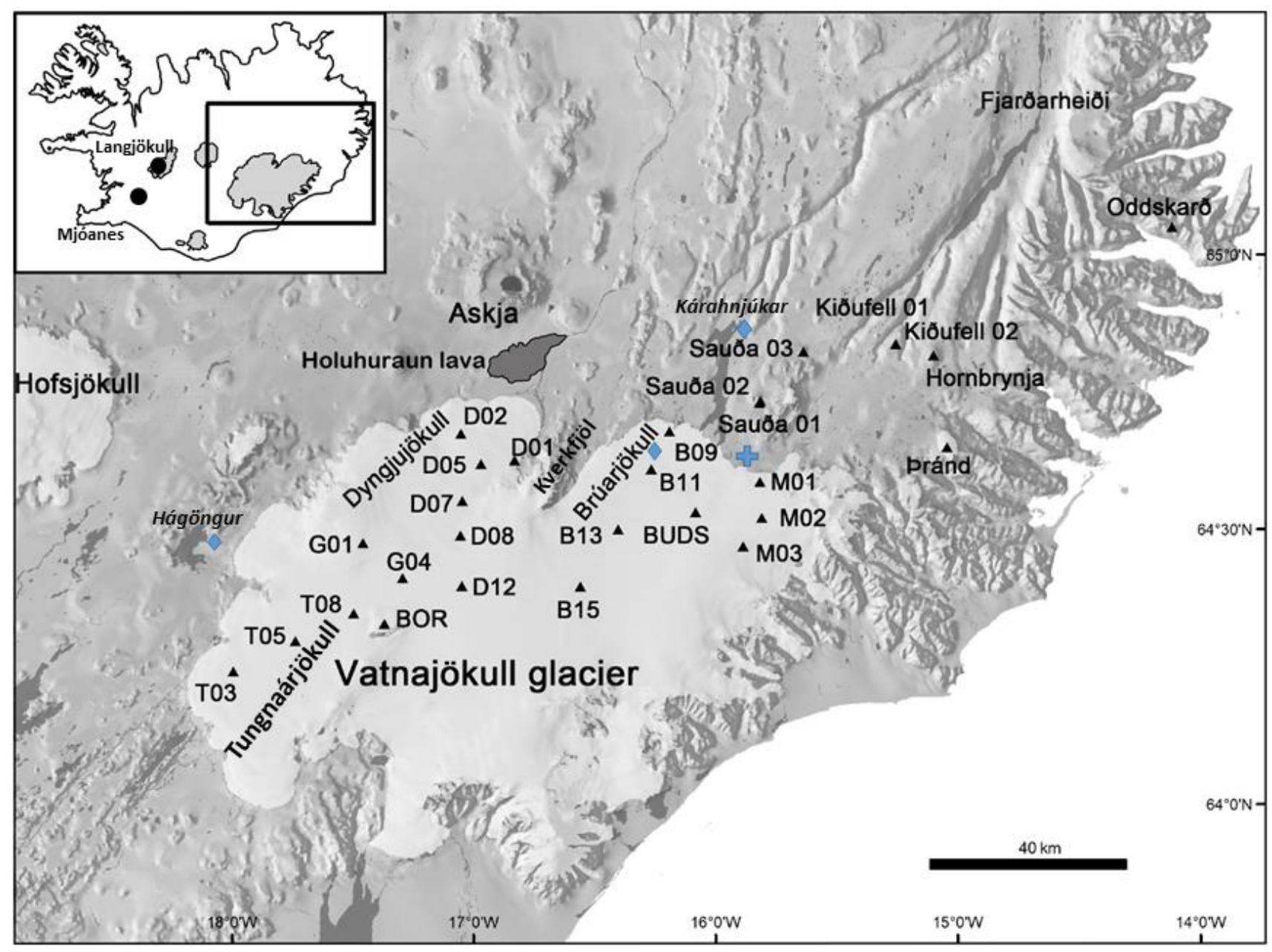

Fig. 1. Sampling locations on the Vatnajökull glacier and in the highlands NE of the glacier. The grey area labelled Holuhraun lava, represents the extent of this lava after the 2014/15 Bárðarbunga eruption. The weather stations operated by IMO on Brúarjökull, Hágöngur, and Kárahnjukar are shown as diamonds. The cross represents the Maríutungur area. Pránd is the snow sample located at the Prándarjökull glacier. The two dots superimposed on the map of Iceland depict the Mjóanes peninsula, the IMO precipitation monitoring station, and the snow coring location on the Langjökull glacier. The G01, G04 and BOR sampling locations are within the Gjálp-Grimsvötn area (see text). 


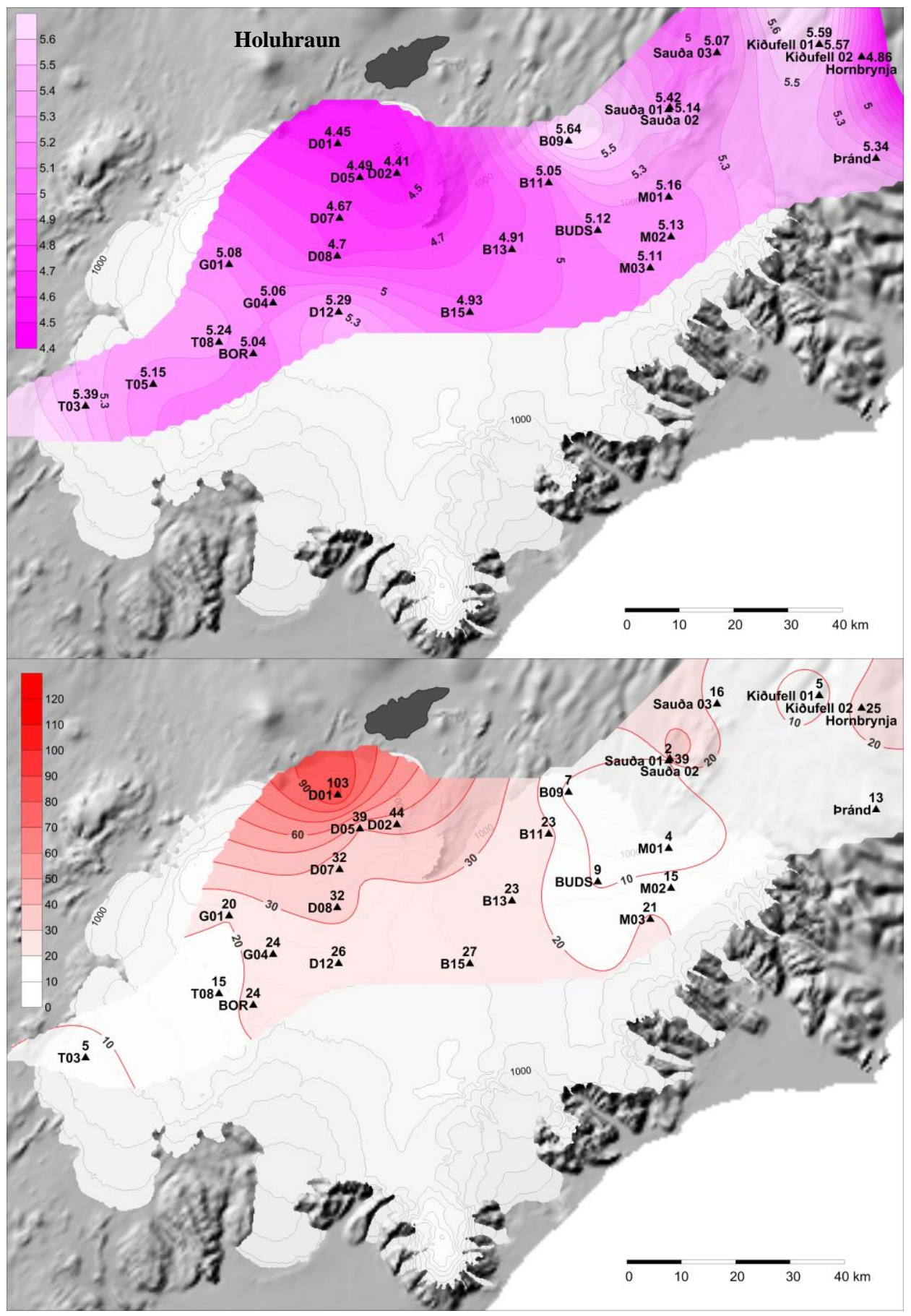

Holuhraun 


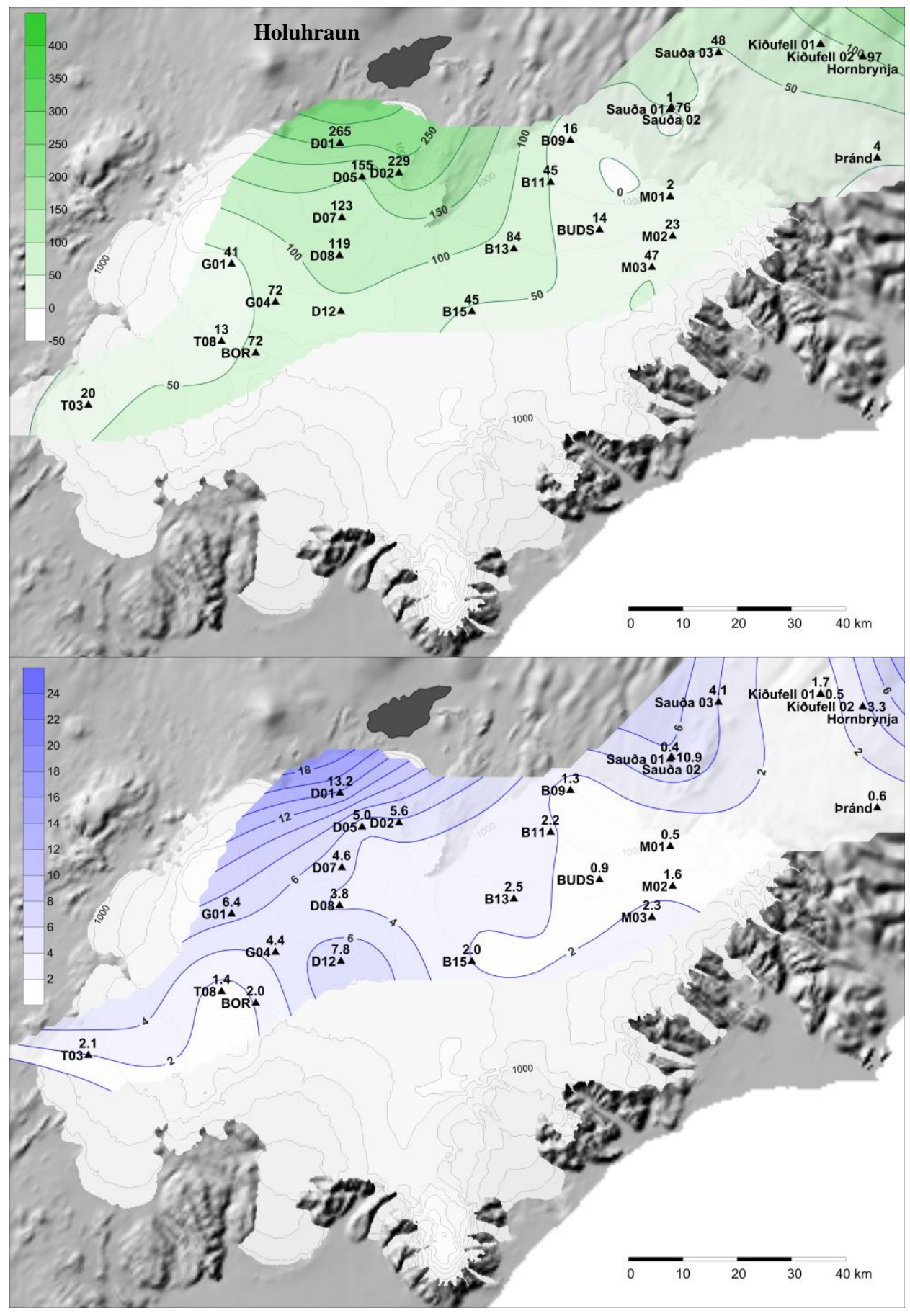

Holuhraun

Fig. 2. Spatial distribution of the measured $\mathrm{pH}$ (a), flux of $\mathrm{S}$ (b), $\mathrm{Cl}$ (c), and $\mathrm{F}$ (d); in ( $\mathrm{mg} / \mathrm{m} 2 / \mathrm{month})$ of the 2014-15 bulk snow cores on the Vatnajökull glacier and in the highlands NE of the glacier. 


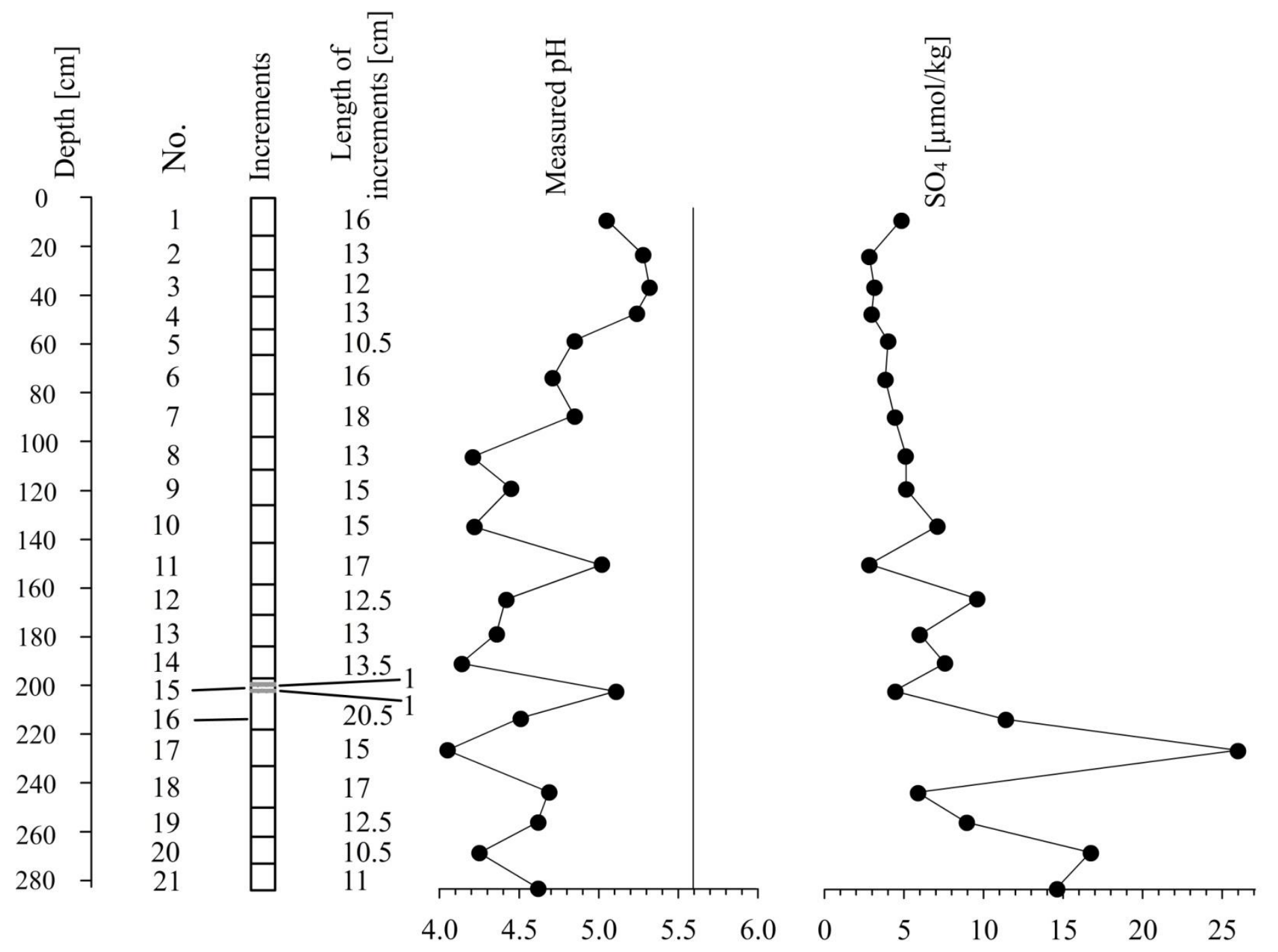

Fig. 3. The $\mathrm{pH}$ and dissolved $\mathrm{SO}_{4}$ concentration (as measured with IC) of D05 snowmelt water as a function of increment depth.The vertical line on the $\mathrm{pH}$ plot represents the $\mathrm{pH}$ of the pure water equilibrated with 395 ppmv of $\mathrm{CO}_{2}$ at $25^{\circ} \mathrm{C}$ as calculated with the PHREEQC computer code. The sampling site is located at an elevation of 1206 m.a.s.l. 

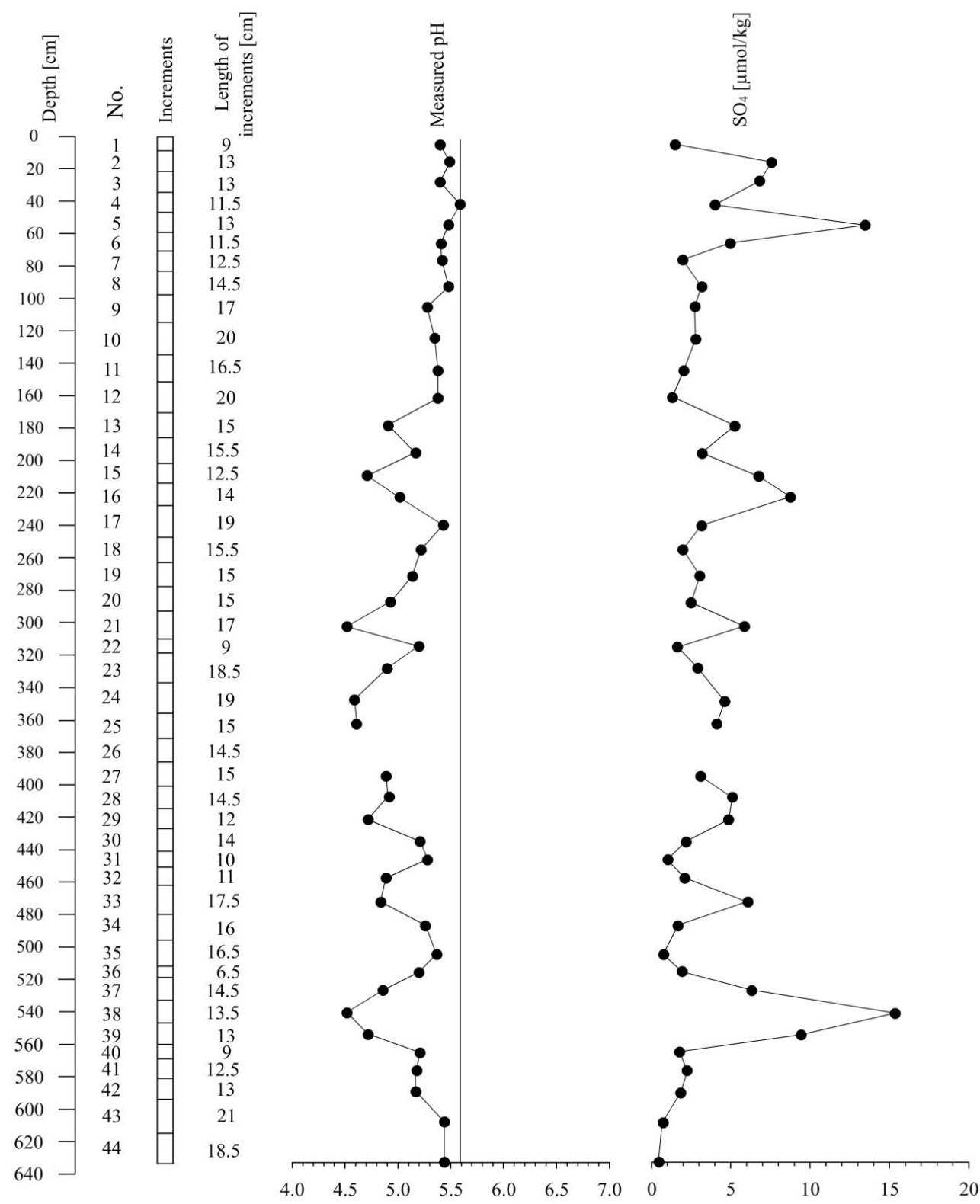

Fig. 4 The $\mathrm{pH}$ and dissolved $\mathrm{SO}_{4}$ concentration (as measured with IC) of M03 meltwater increments as a function of depth. The vertical line on the $\mathrm{pH}$ plot represents the $\mathrm{pH}$ of the pure water equilibrated with $395 \mathrm{ppmv}$ of $\mathrm{CO}_{2}$ at $25^{\circ} \mathrm{C}$ as calculated with the PHREEQC computer code. The sampling site is located at an elevation of 1331 m.a.s.l. 

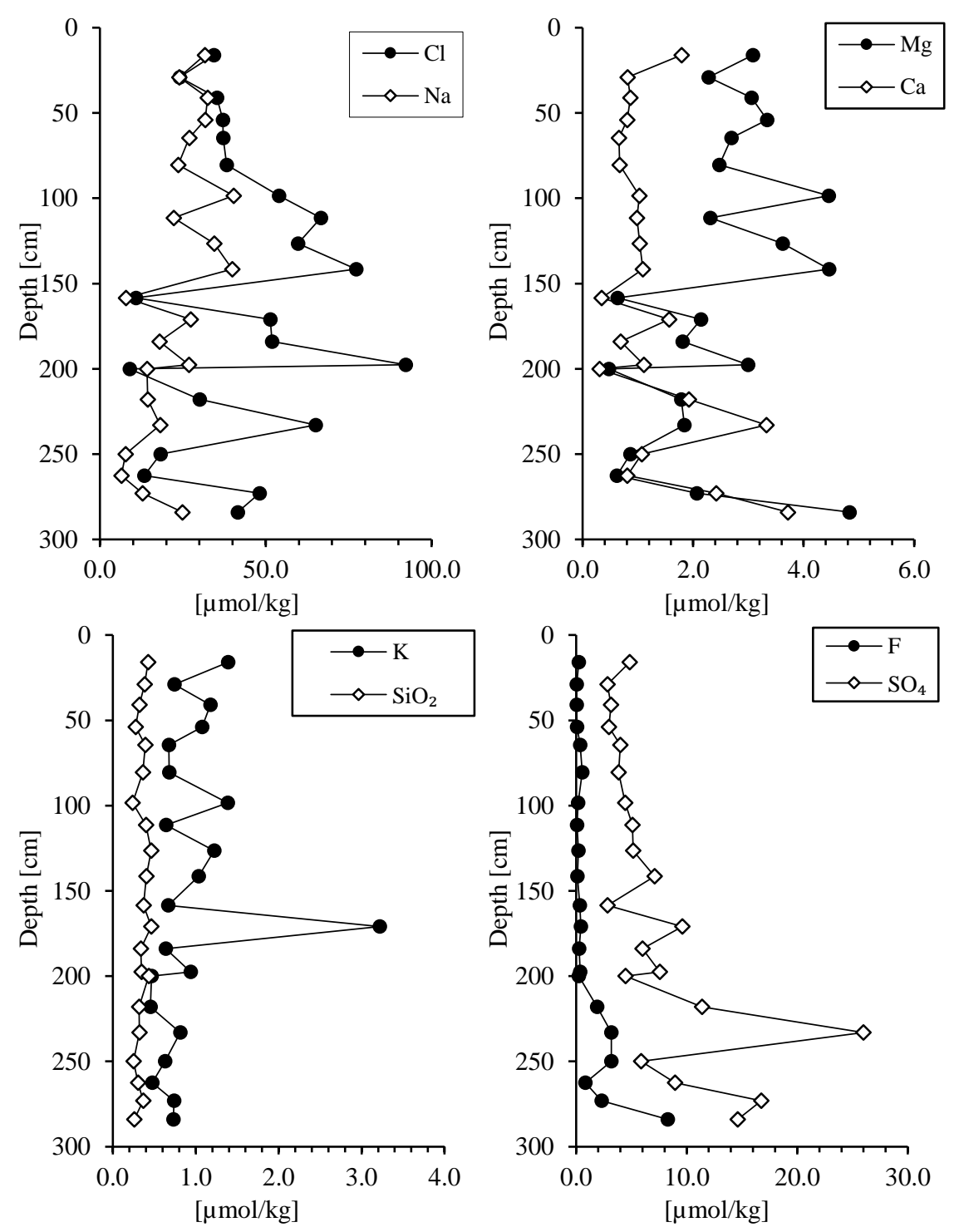

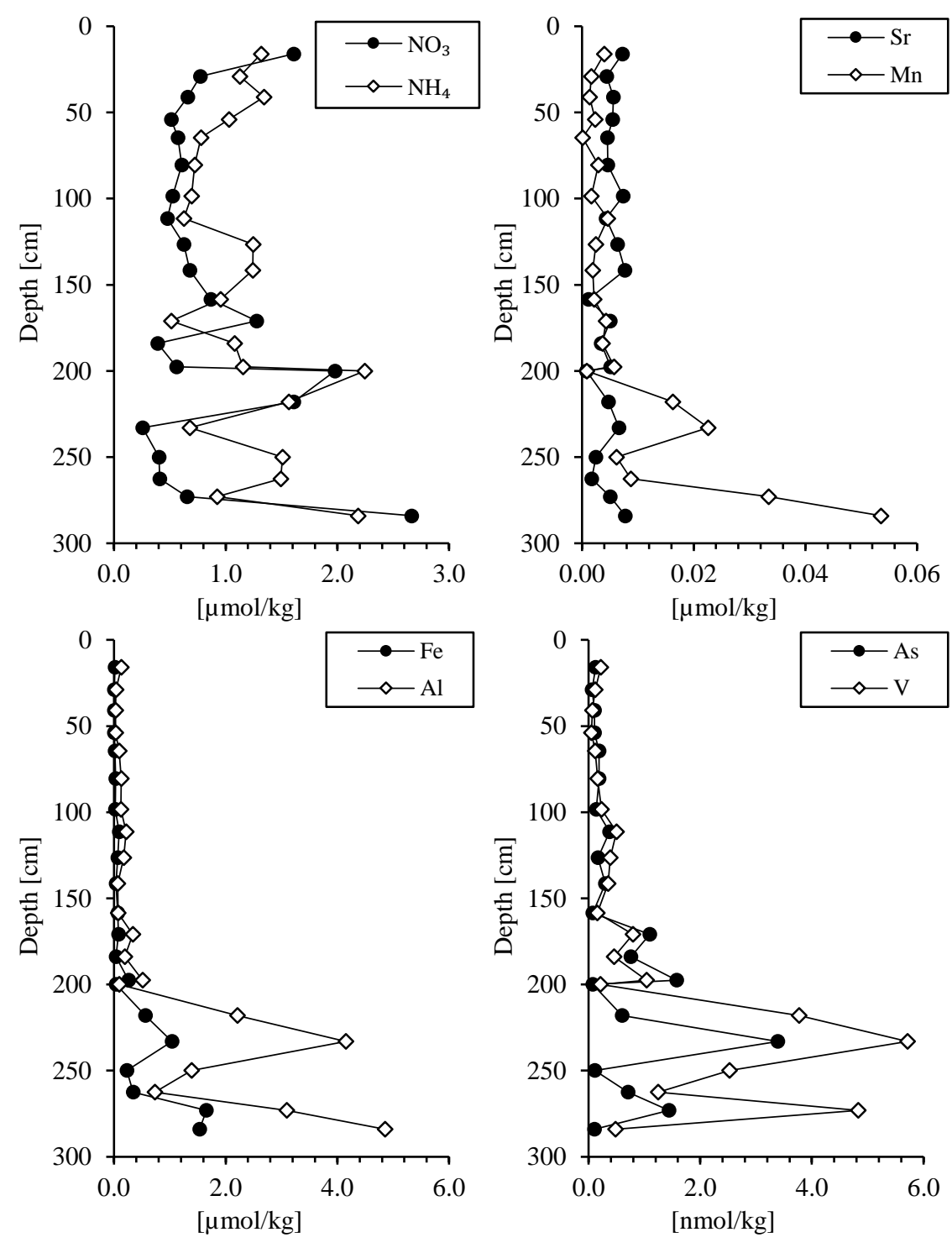

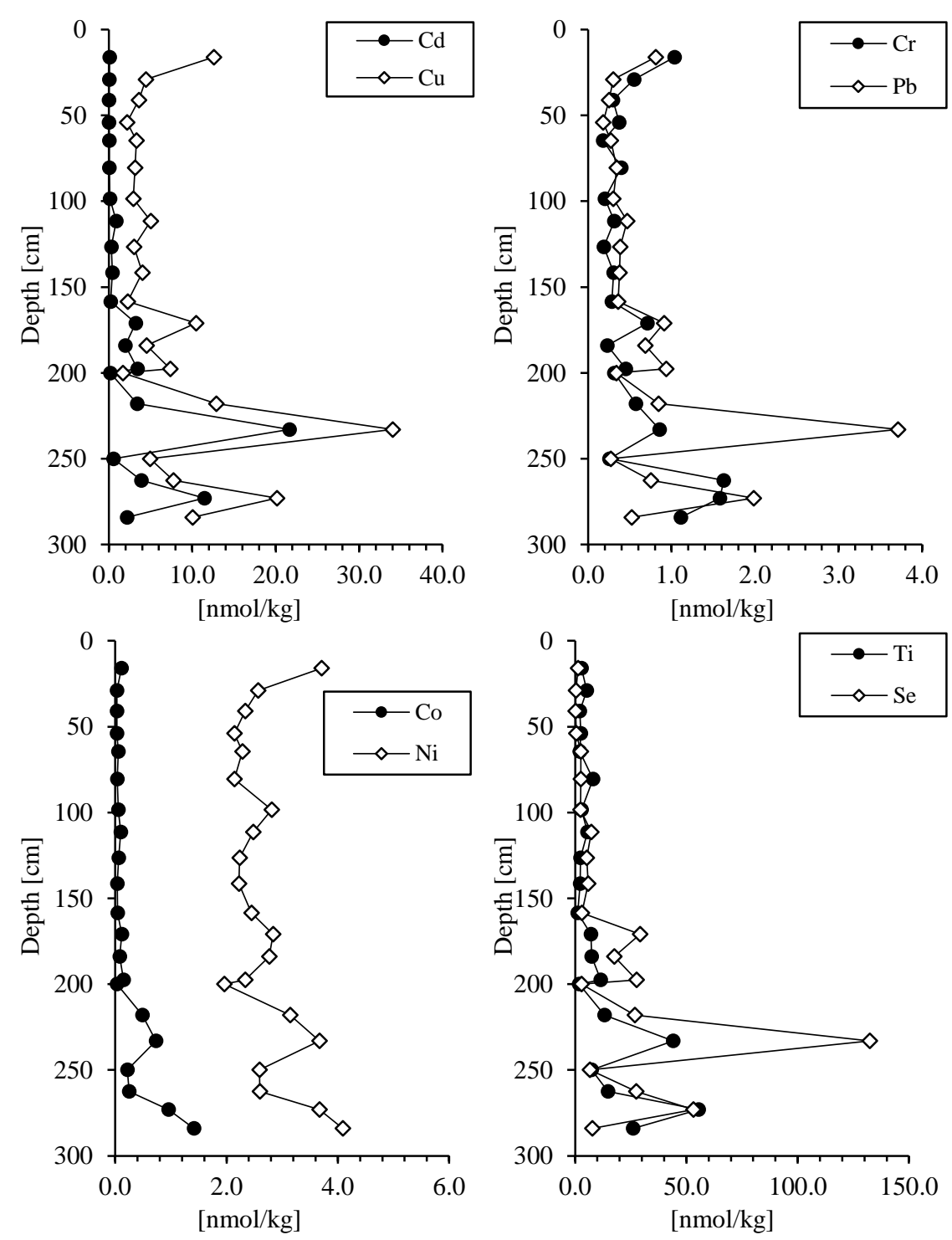

Fig. 5. The concentrations of major and trace dissolved elements with depth in snow core D05. Snow that fell during the most effusive period of the volcanic eruption in early winter is located in the deepest part of the snow core. 

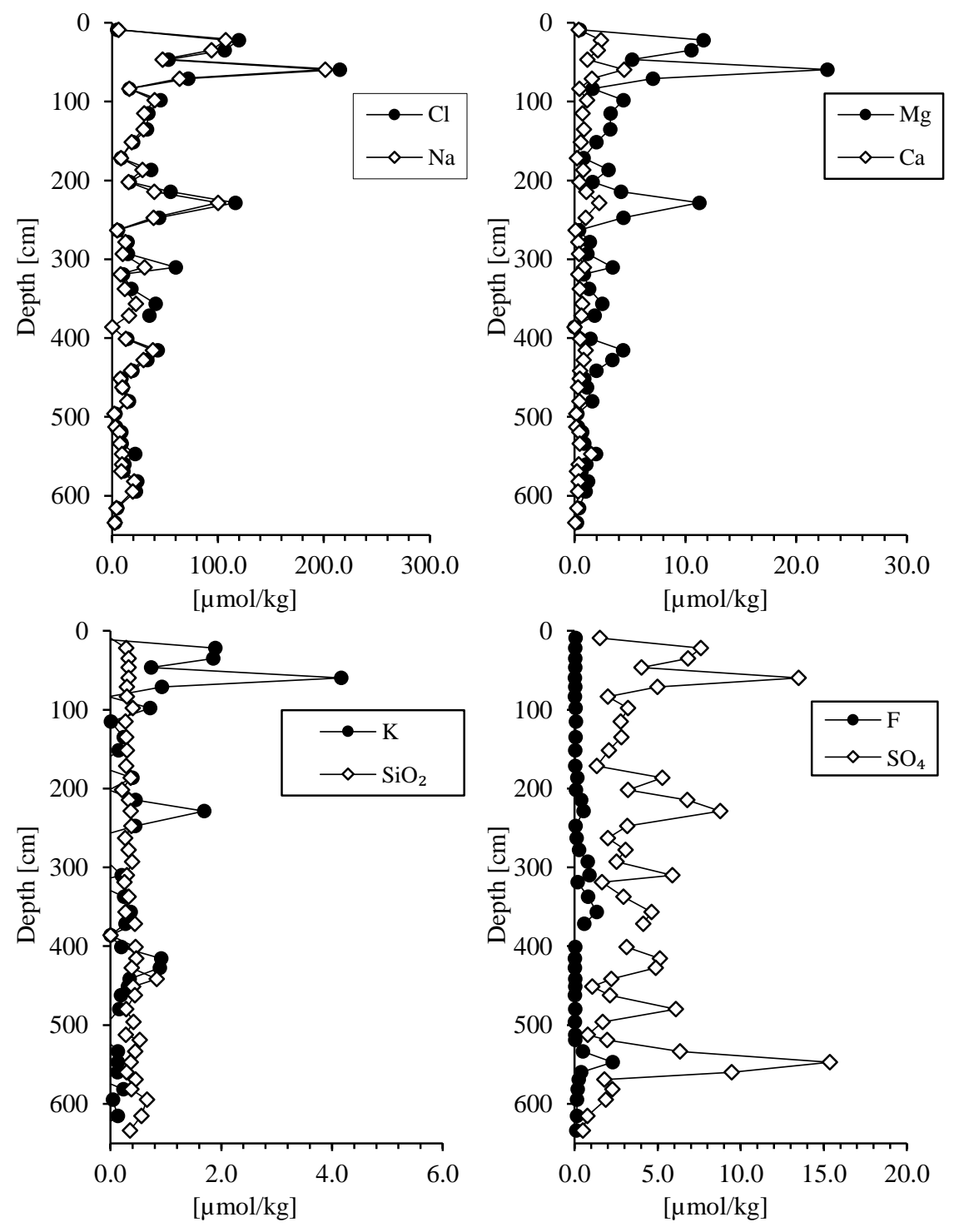

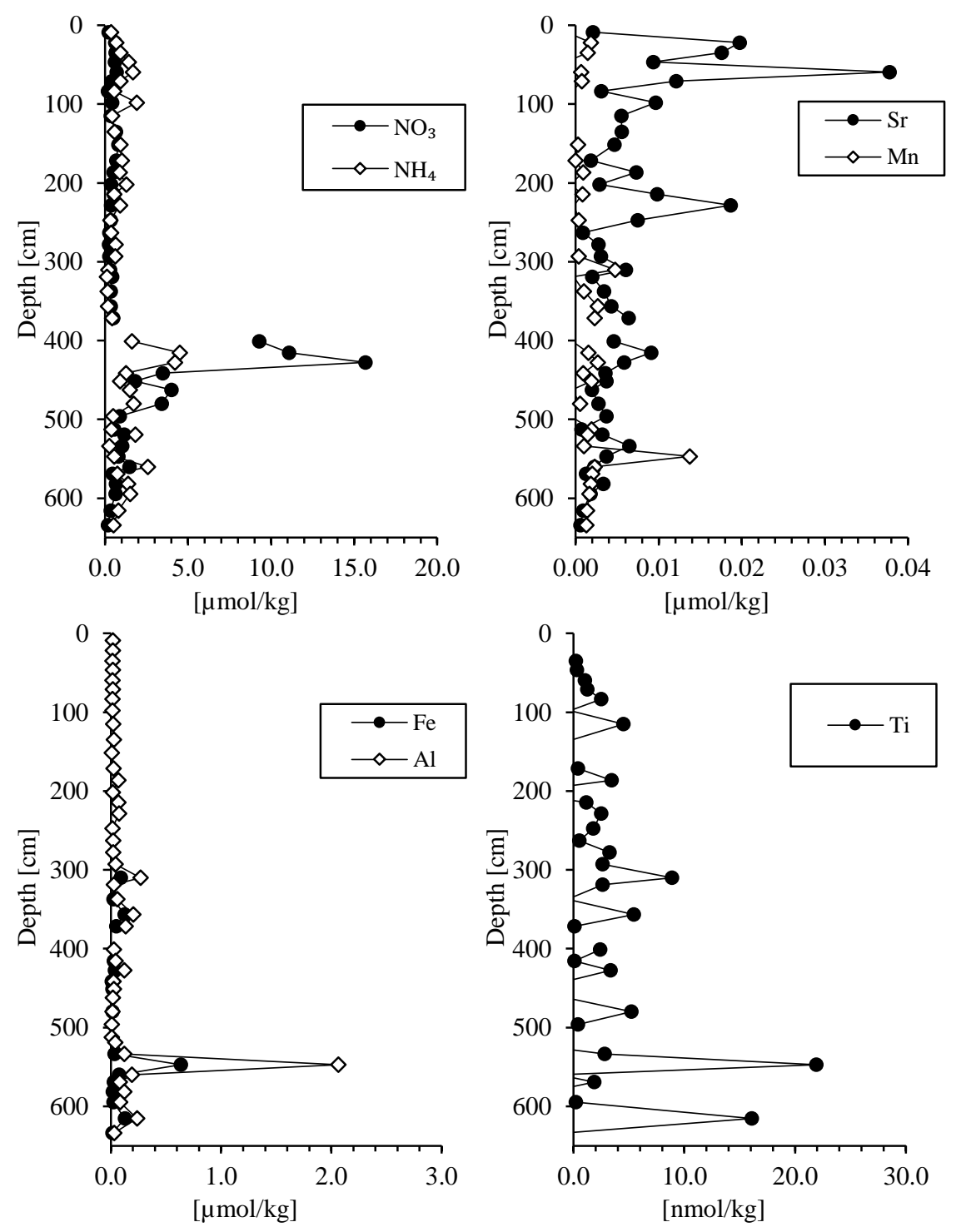

Fig. 6. The concentration of major and trace dissolved elements with depth in snow core M03. Snow that fell during the most effusive period of the volcanic eruption in early winter is located in the deepest part of the snow core. 

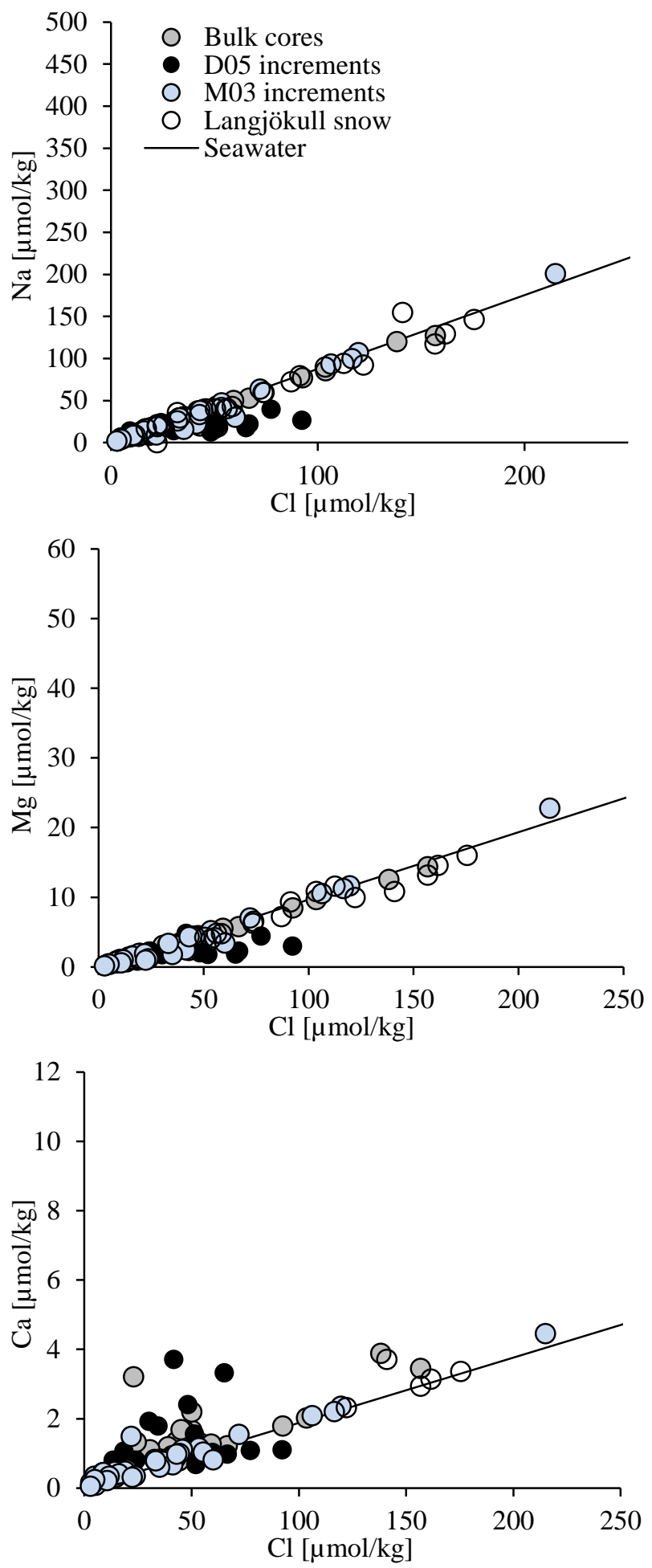

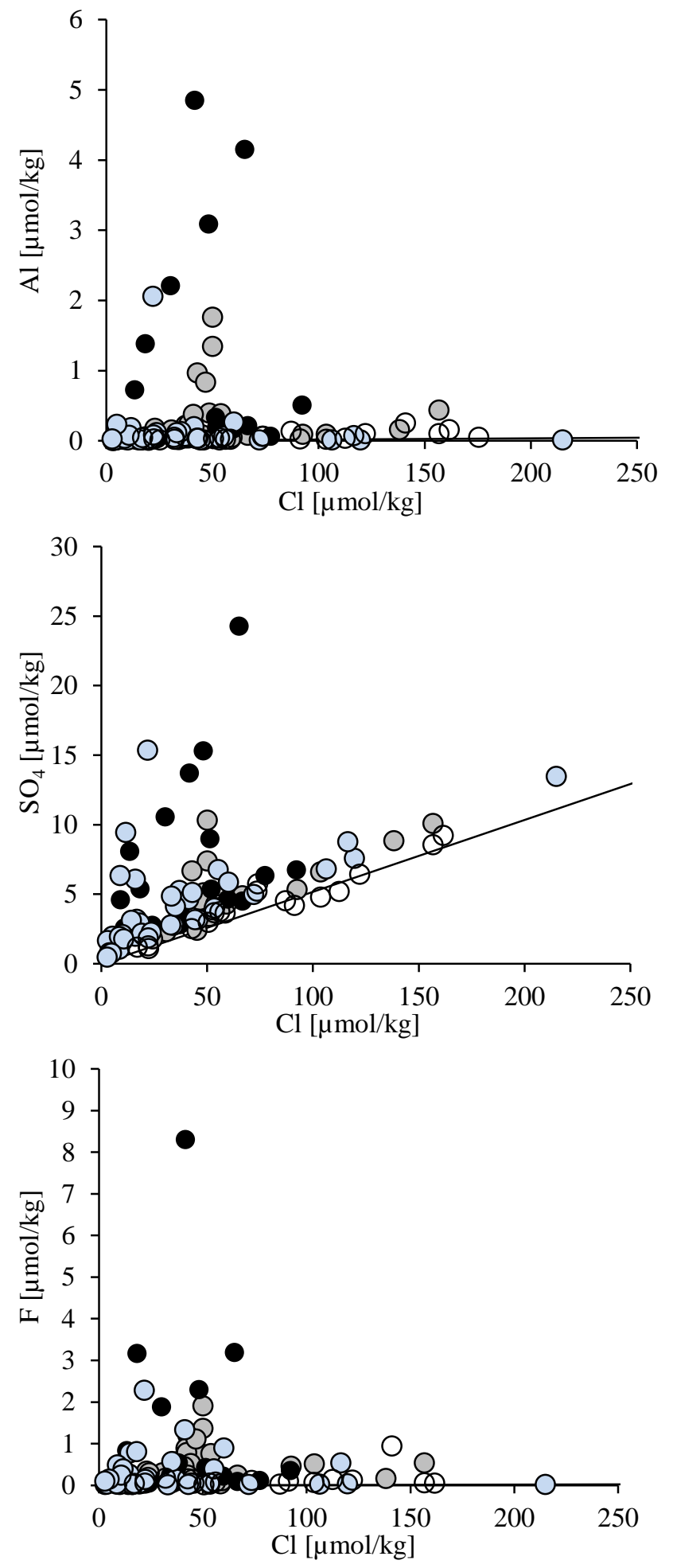

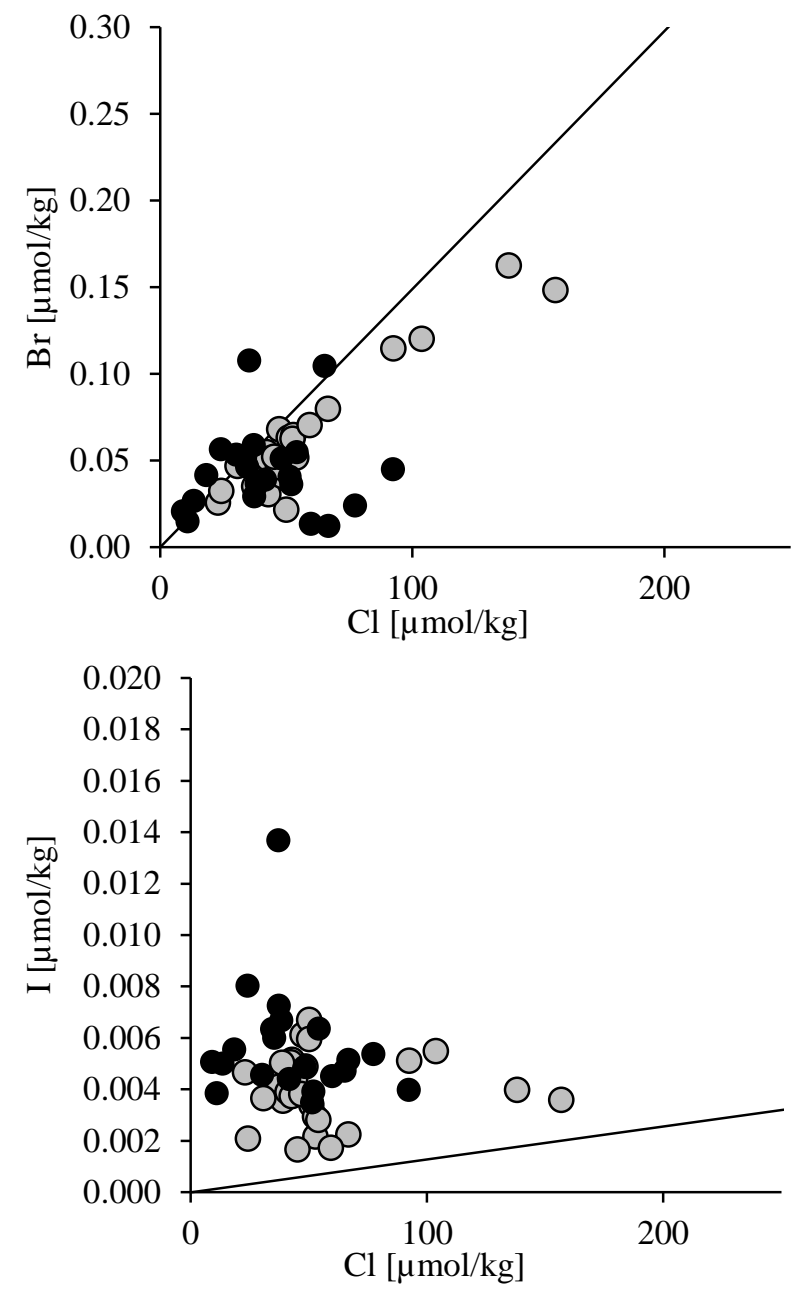

Fig. 7. The ratios of elements to $\mathrm{Cl}$ in the snowmelt collected from theVatnajökull glacier and the highlands NE of the glacier, and from the reference Langjökull winter snow collected in 19972006. The seawater ratio was taken from Bruland (1983). 

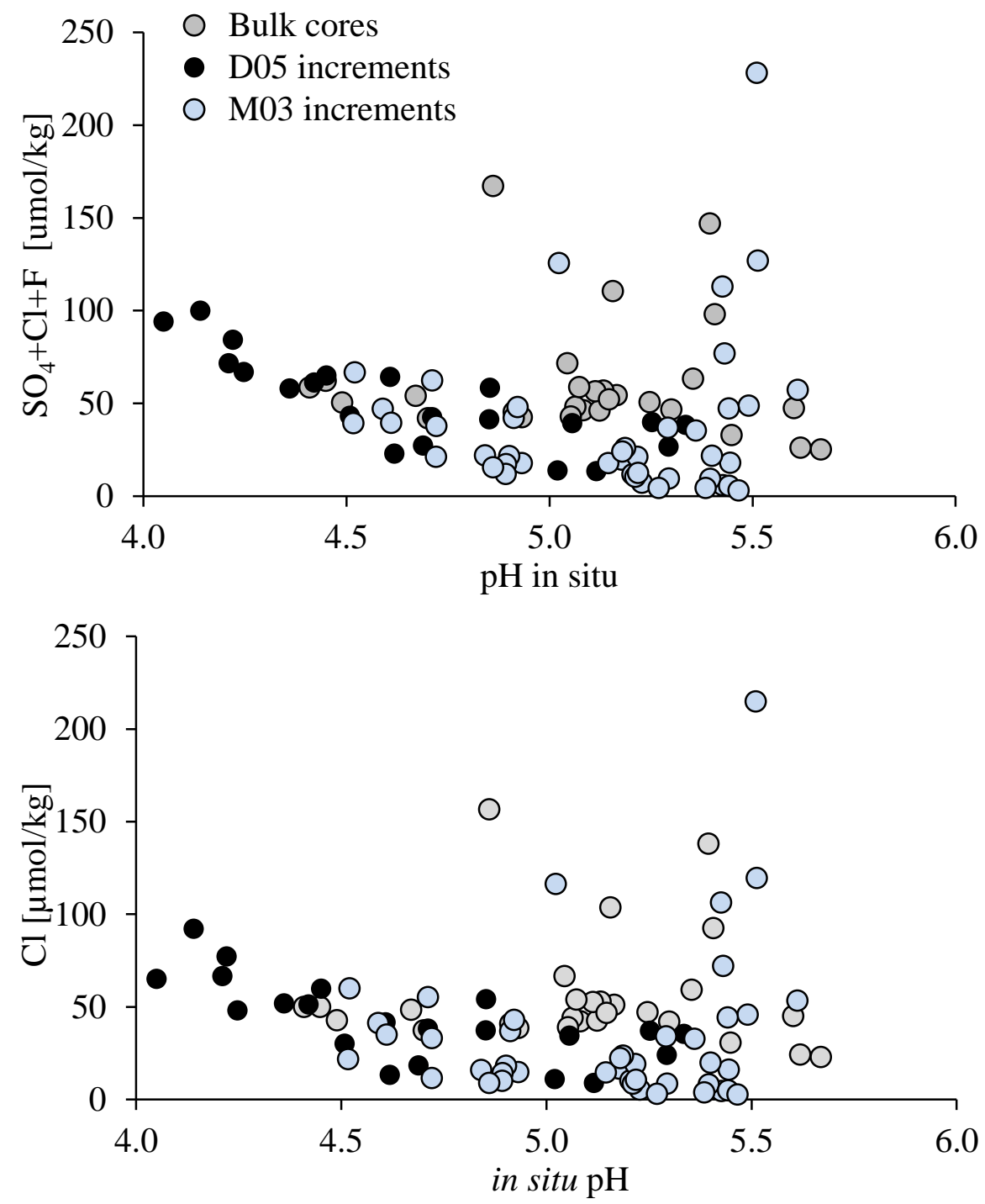

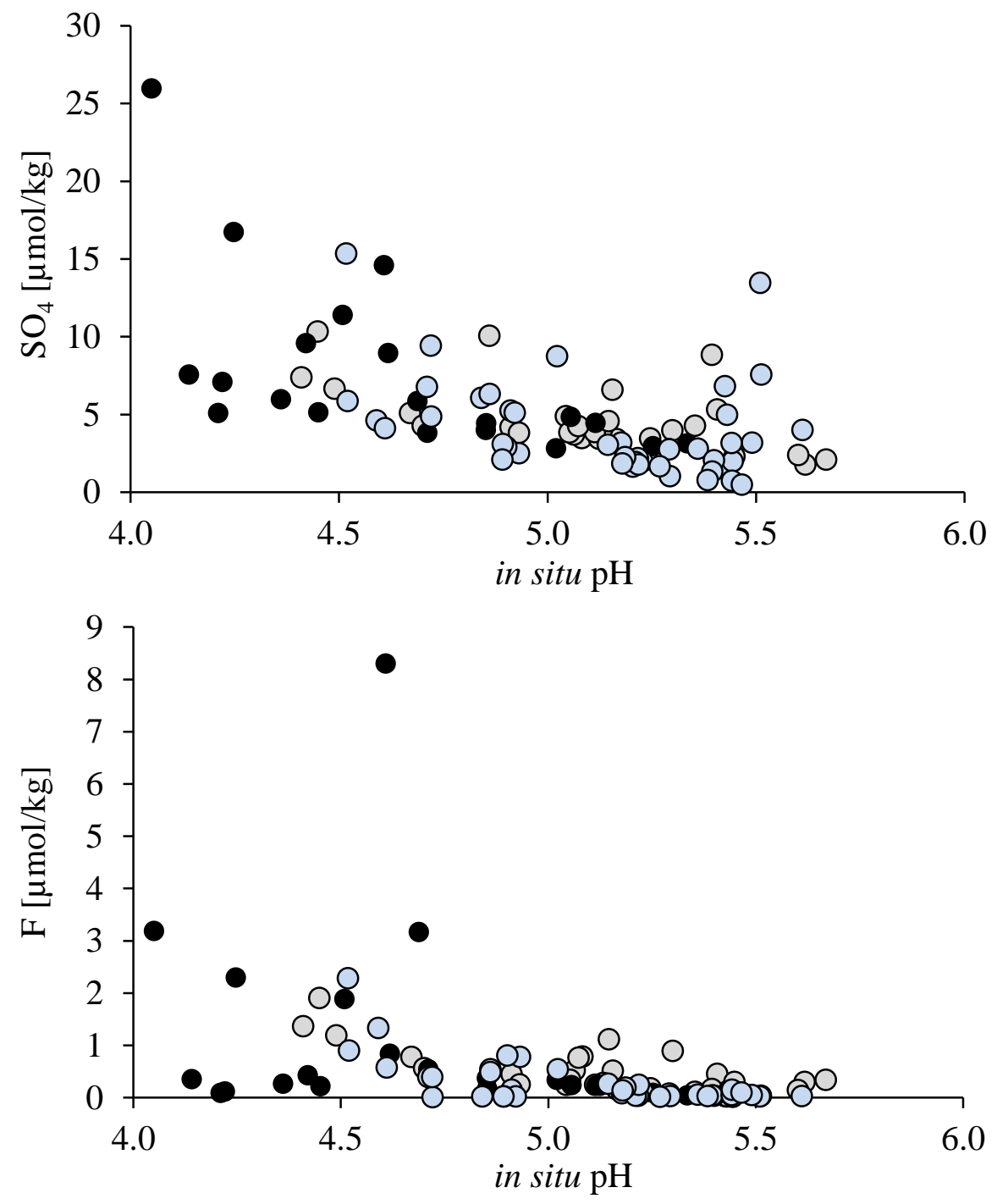

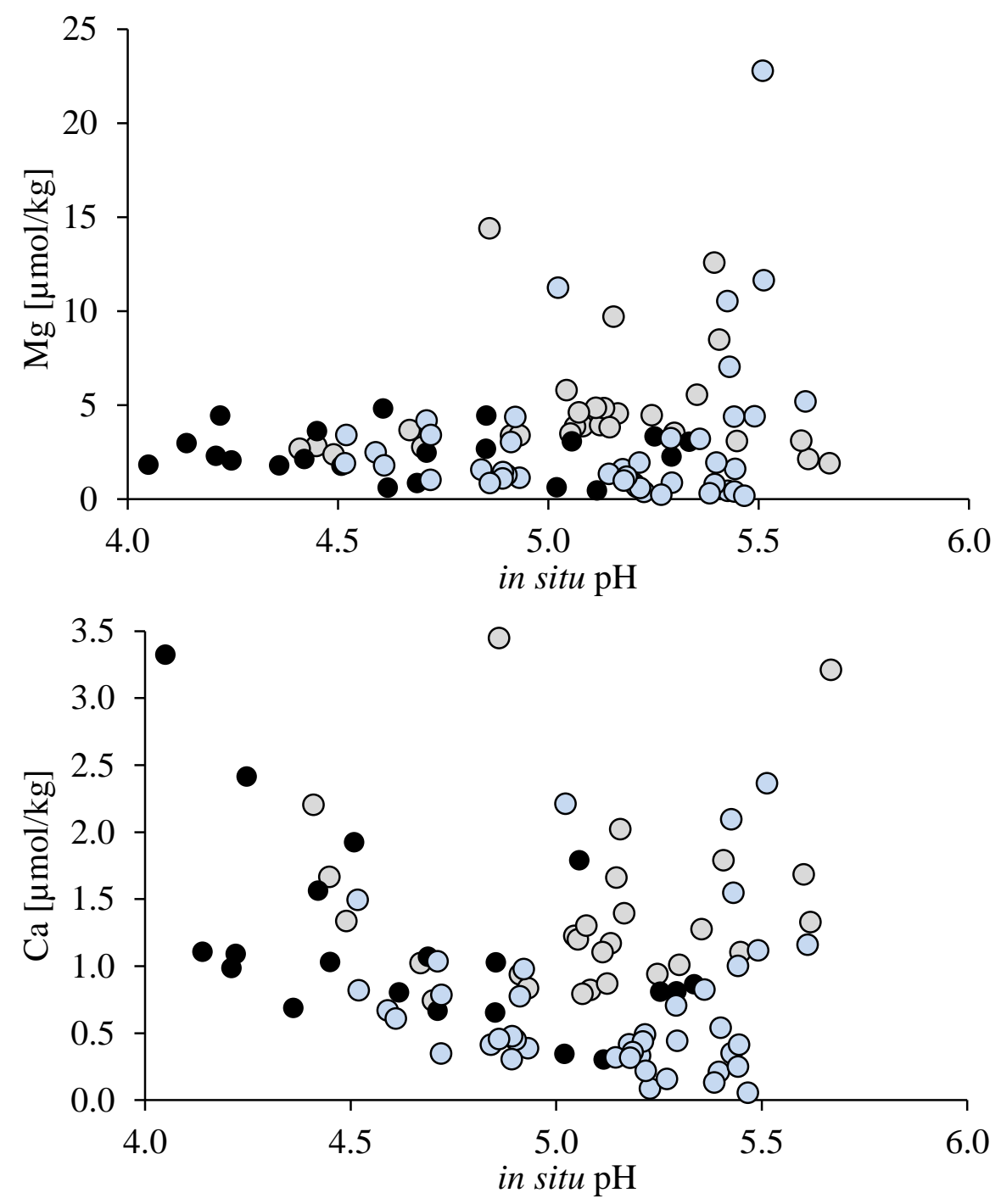

Fig. 8. The concentrations of selected elements as a function of the in situ $\mathrm{pH}$ of the snow samples. The in situ $\mathrm{pH}$ was calculated using PHREEQC computer code. 

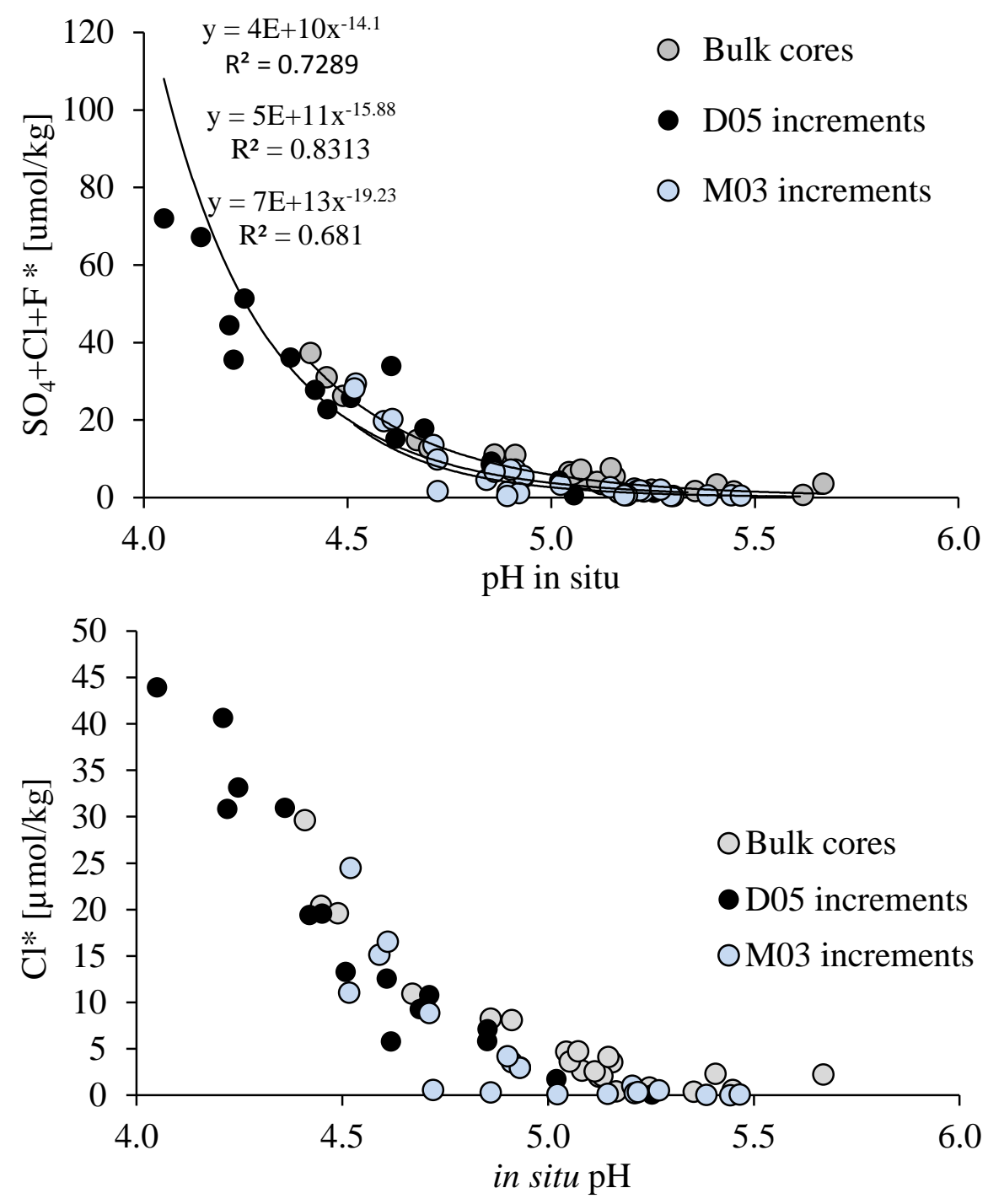

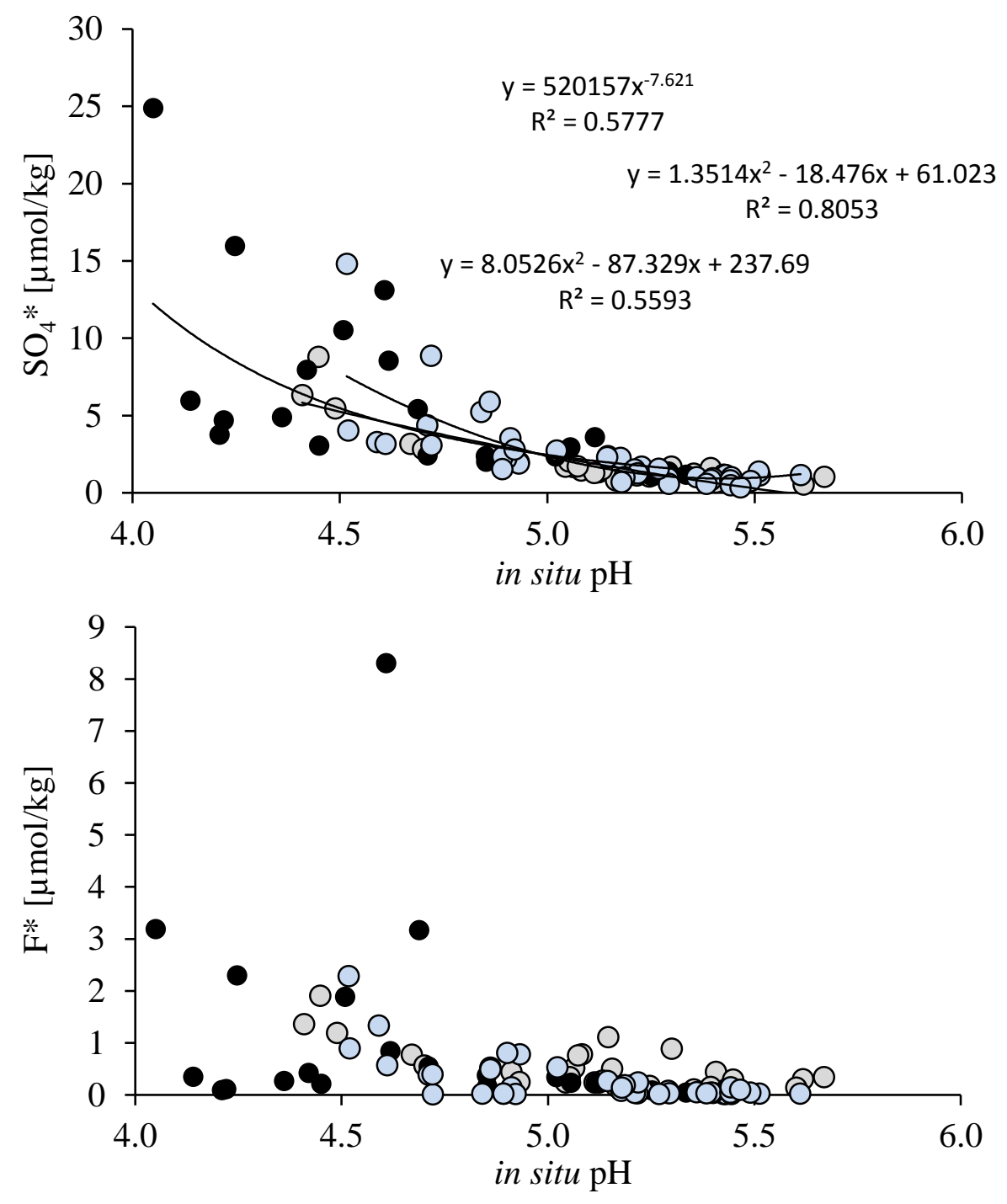

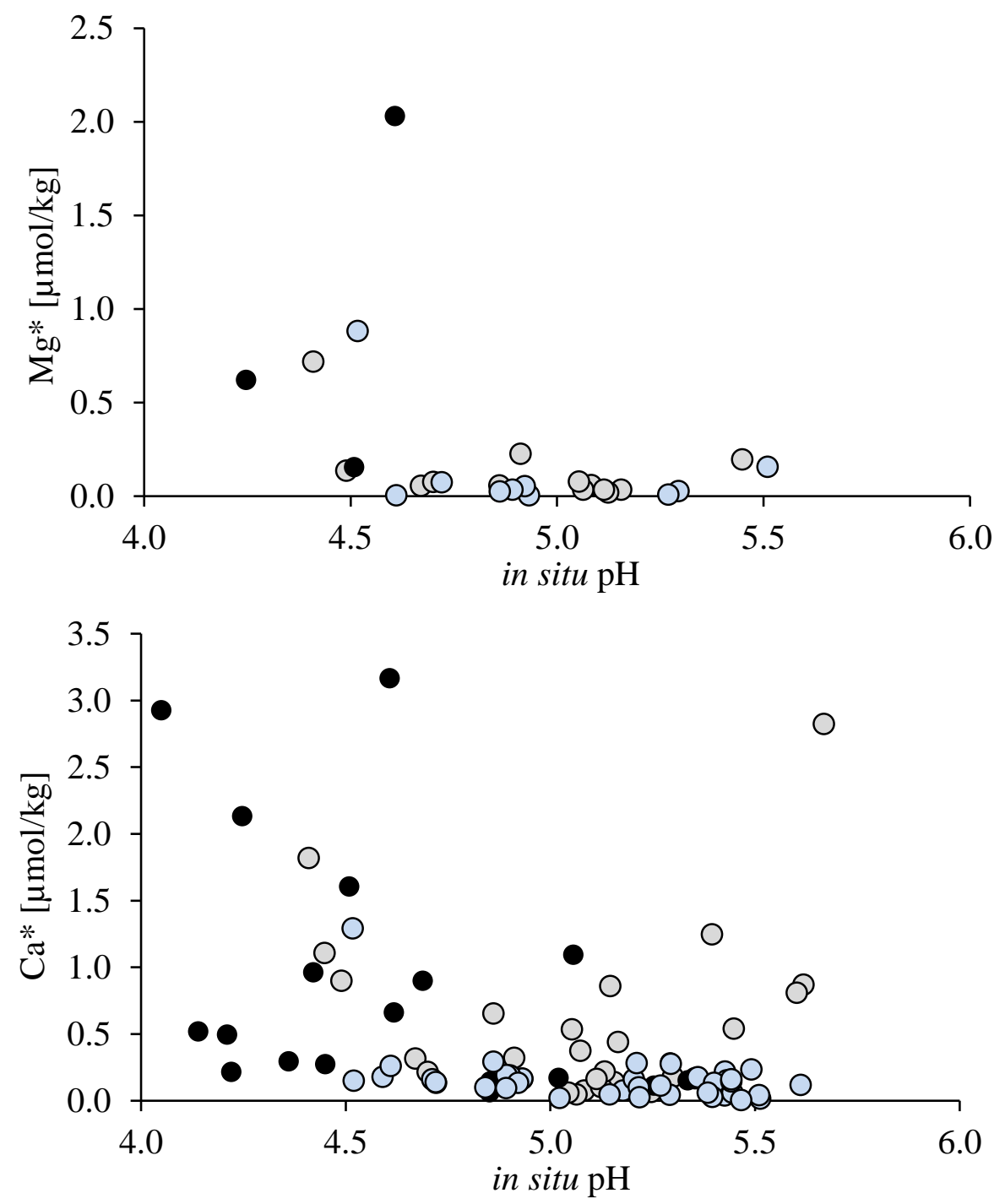

Fig. 9. The concentrations of selected components in snow versus in situ $\mathrm{pH}$. Cncentrations were corrected for the seawater component as described in the text. The in situ $\mathrm{pH}$ was calculated using PHREEQC computer code. 


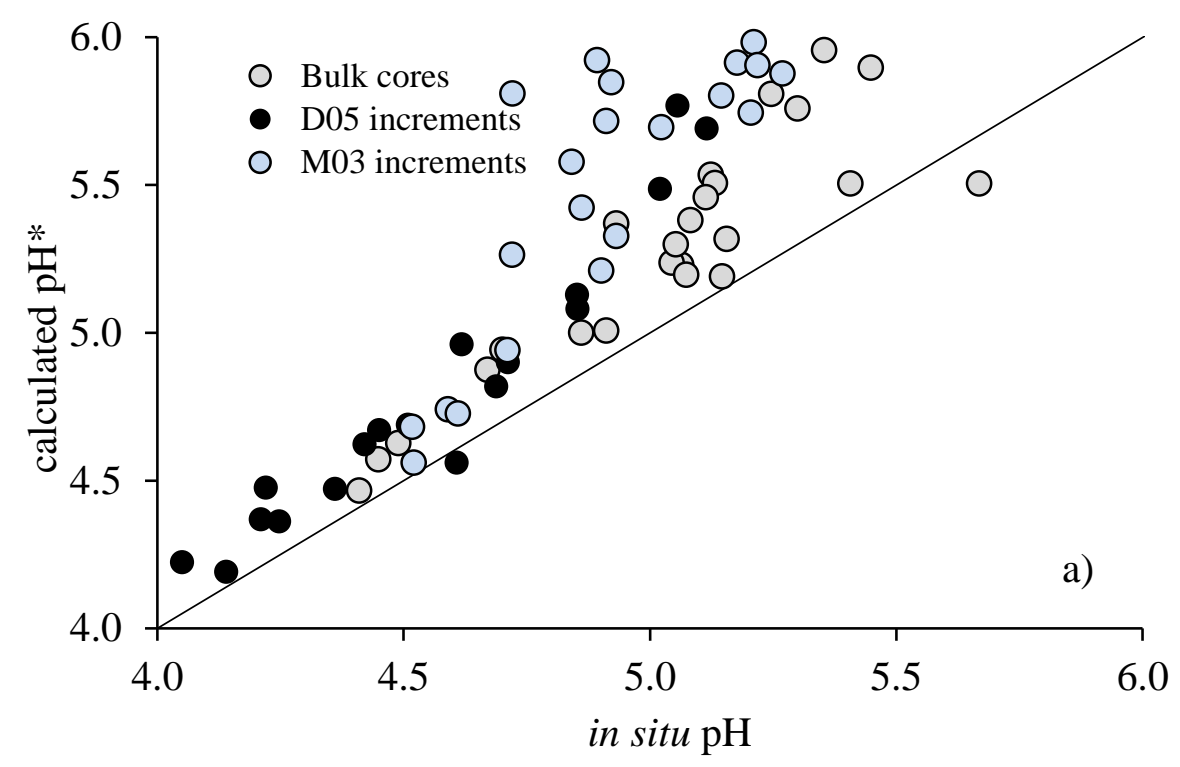

Fig. 10. The calculated $\mathrm{pH}$ based on the seawater uncorrected (a) and seawater corrected (b) $\mathrm{Cl}$, $\mathrm{SO}_{4}$, and $\mathrm{F}$ concentrations versus in situ $\mathrm{pH}$ of snow samples. 


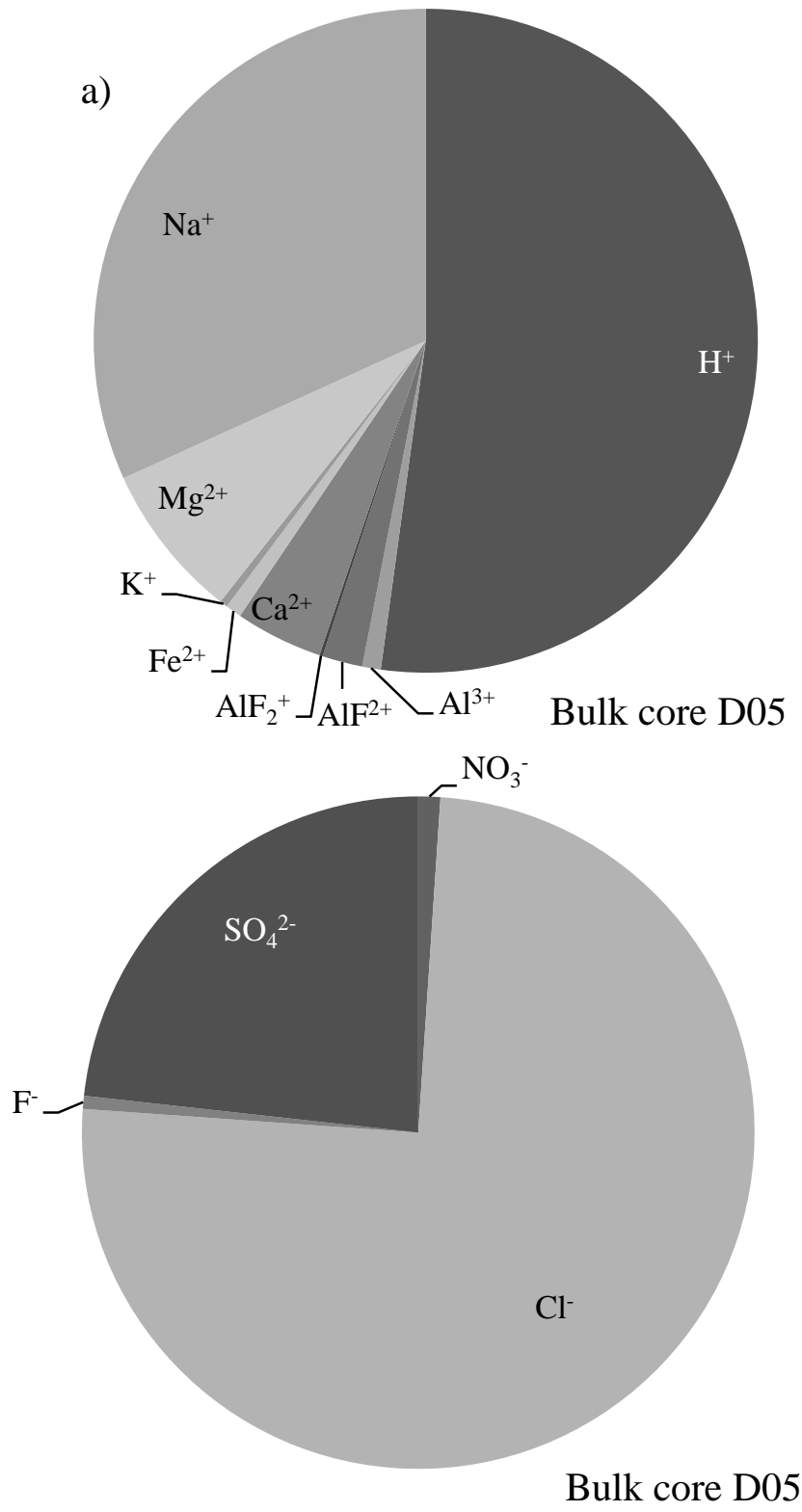

b) 


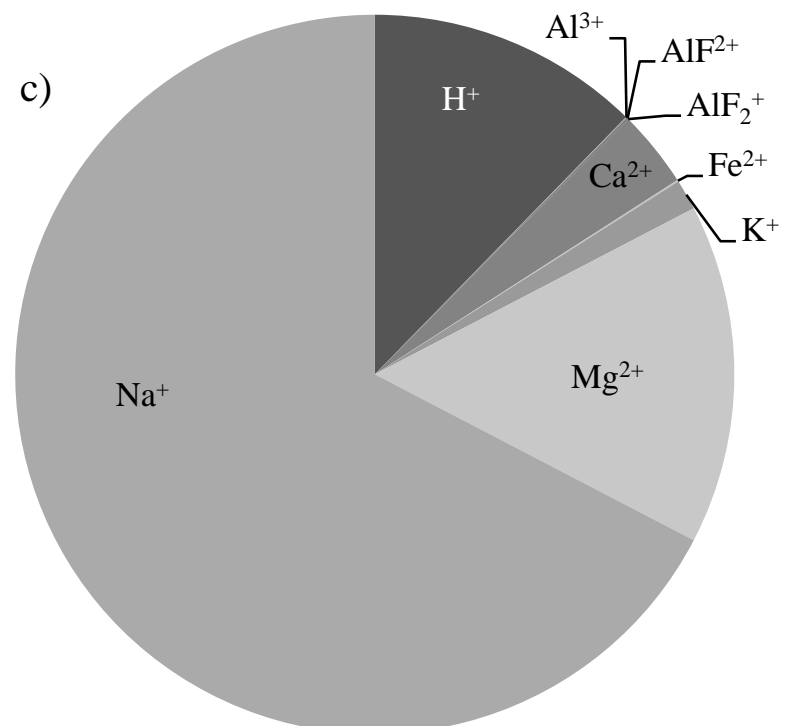

d)

Bulk core M03

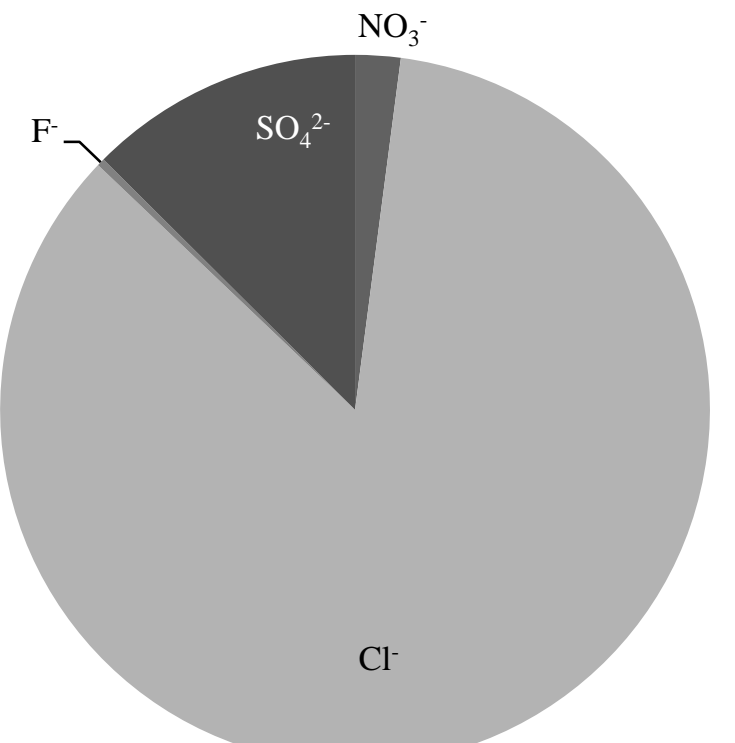

Bulk core M03 


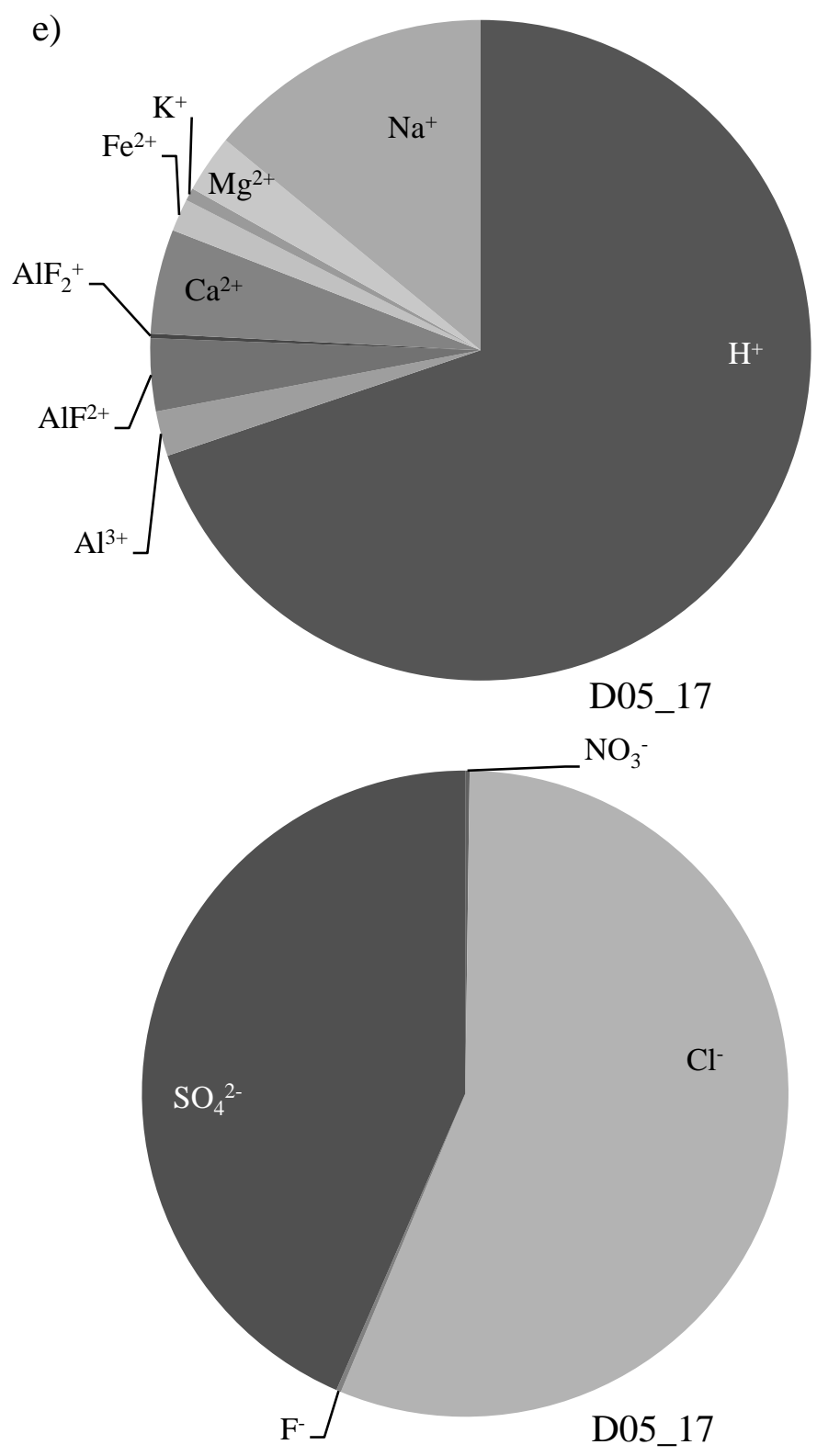

f)

Fig. 11. The aqueous species dominating the charge balance of the D05 bulk core (a, b), M03 bulk core $(\mathrm{c}, \mathrm{d})$, and in the most acidic increment D05_17 shown as percent of charge contributed by each species. Cations are illustrated on the left (a, c, e), anions on the right (b, d, f). Speciation distribution was calculated at $25{ }^{\circ} \mathrm{C}$ using measured dissolved constituents and the PHREEQC computer code. 

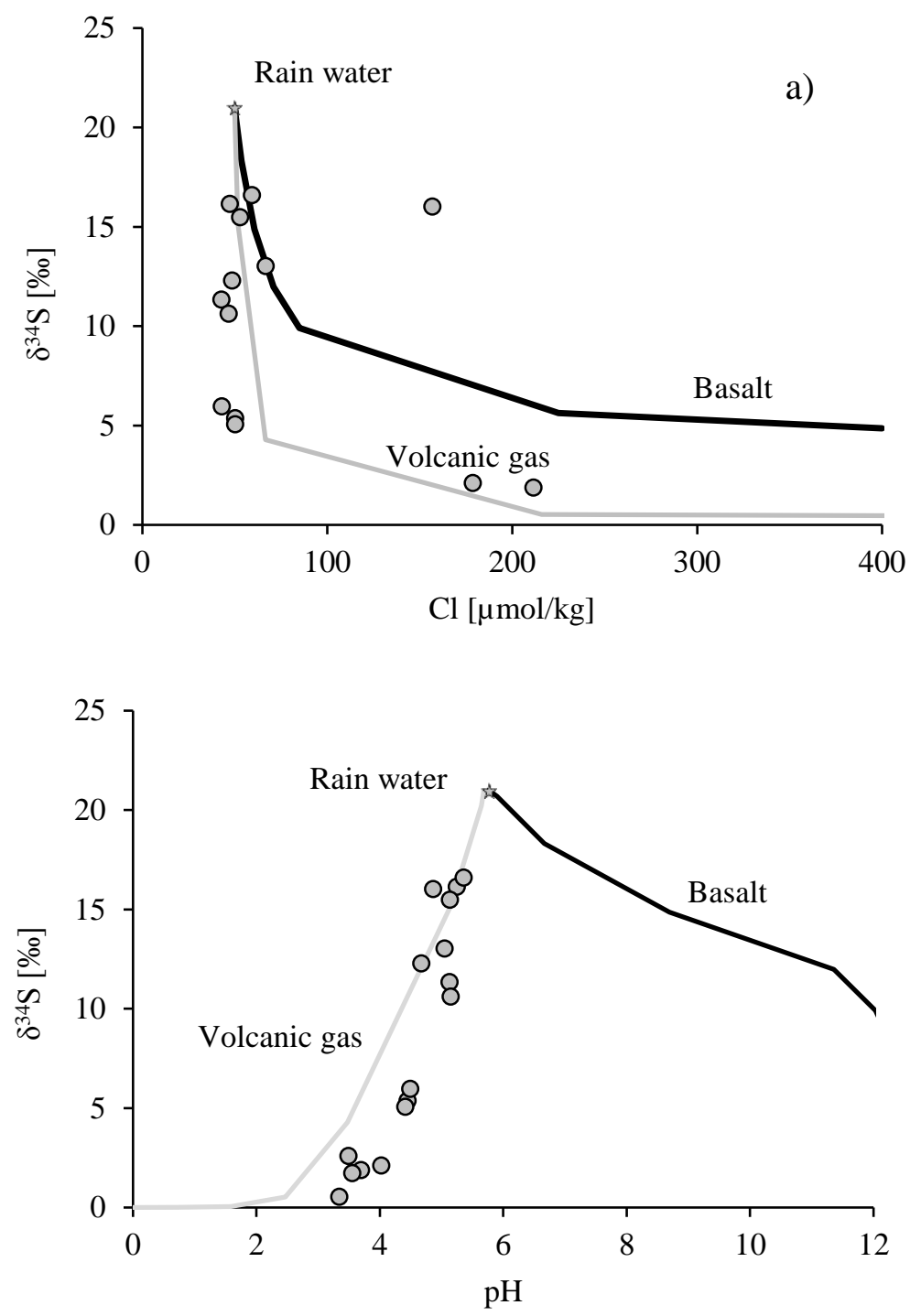

Fig. 12. The results of the mixing model (a) and the reaction path simulation (b). The lines represent the theoretical composition of the final fluid when basalt (simulation 1) and volcanic gas (simulation 2), respectively are assumed to be dissolved in unpolluted seawater originating rain water. The dots represent measured concentrations in the snow. 